\title{
Conselhos Gestores de Políticas Públicas no Município de São Paulo: identidade, limitações e potencialidades na perspectiva da Promoção da Saúde
}

Cláudia Maria Bógus

Tese apresentada à Faculdade de Saúde Pública da Universidade de São Paulo para obtenção do título de Livre-Docente, junto ao Departamento de Prática de Saúde Pública.

São Paulo

2009 
É expressamente proibida a comercialização deste documento, tanto na sua forma impressa como eletrônica. Sua reprodução total ou parcial só é permitida exclusivamente para fins acadêmicos e científicos, desde que na reprodução figure a identificação do autor, título, instituição e ano da tese. 
AGRADECIMENTOS

I get by with a little help from my friends I get high with a little help from my friends yeah, gonna try with a little help from my friends.

A little help from my friends - Paul McCartney e John Lennon 



\section{AGRADECIMENTOS}

São muitos e todos os auxílios foram imprescindíveis!

À Fundação de Amparo à Pesquisa do Estado de São Paulo, pelo financiamento do Projeto Conselhos Municipais: possíveis contribuições para políticas públicas saudáveis na perspectiva da promoção da saúde (Processo FAPESP no 2005/02979-8).

Aos funcionários do Departamento de Prática de Saúde Pública, Lívia, Sonia, Cidinha, Sandra, Antonio e Valdívia, pelo apoio diário.

Às companheiras do Grupo de Apoio Pedagógico da Faculdade de Saúde Pública: professoras Regina, Ana, Dirce, Ana Maria e Fátima; nutricionista Monica; estudantes Sabrina, Mariana, Nadine, Cynthia, Ariana, Fernanda e Viviana; e à assessora pedagógica Otília, pela parceria.

Às colegas do cotidiano institucional, Cleide, Claudia, Adelaide, Maria Tereza, Nicolina e Helena, pela amizade. E à Marcia, pelo permanente incentivo.

Aos orientandos de categorias diversas dos últimos cinco anos: Regina, Marta, Vitor, Greice e Patricia (monitoria na graduação); Tania, Evelin, Sabrina, Juliana, Natália, Camila e Denise (iniciação científica); Cynthia e Vanessa (ensinar com pesquisa); Mariza, Bete, Andréia, Mariana, Vanessa e Silvia (programa de aperfeiçoamento do ensino); Christiane, Bete, Andréia, Marcia, Ayodele e Nayara (mestrado) e Crhistinne, Silvia e Vanessa (doutorado), pela valiosa oportunidade de vivenciar o processo de ensinagem. 
Aos membros do Clube do Espelho, Sonia, Biba, Julio, Cezira, Luiz Antonio e Luci, pela solidária e bem-humorada torcida.

Aos núcleos familiares, de João Pessoa (vocês fazem falta!), do Jaguaré e das Perdizes, pelo carinhoso apoio. 


\section{RESUMO}



RESUMO

Conselhos Gestores de Políticas Públicas no Município de São Paulo: identidade, limitações e potencialidades na perspectiva da Promoção da Saúde

Os Conselhos Gestores de Políticas Públicas são instâncias formalizadas e institucionalizadas de participação social, estabelecidos a partir da Constituição Federal de 1988. Foram criados como canais de participação e são indicativos da presença e atuação dos movimentos sociais e outras organizações na sociedade civil. O estudo dessas instâncias participativas tem sido indicado, a partir do pressuposto de que a participação em fóruns desse tipo pode fomentar um círculo virtuoso, desde a mobilização e o envolvimento dos cidadãos até o fortalecimento da democracia, propiciando a construção de uma cultura cívica.

O marco conceitual da Promoção da Saúde também serve como referência para a discussão de políticas públicas que repercutam na melhoria das condições de saúde da população, por seus pressupostos de ação intersetorial e participação social.

Realizou-se um estudo junto a instâncias participativas, características de diferentes níveis da gestão de políticas públicas municipais de São Paulo: Conselhos Municipais de Meio Ambiente e Desenvolvimento Sustentável, de Saúde e de Segurança Alimentar e Nutricional; e, no nível local, junto aos Conselhos Gestores das Supervisões Técnicas de Saúde de São Miguel Paulista, Ermelino Matarazzo e Vila Mariana, com o objetivo de: identificar o perfil sócio-demográfico dos seus membros; identificar as associações e/ou entidades a que pertencem os membros; caracterizar e analisar o perfil das associações e/ou entidades a que pertencem os membros dos referidos Conselhos e as relações existentes entre elas e identificar a percepção dos membros quanto às possibilidades de articulação e integração dos conselhos na formulação de políticas públicas intersetoriais.

A coleta de dados foi feita por meio de levantamento documental, realização de entrevistas individuais com 30\% dos conselheiros dos seis Conselhos estudados e observação de reuniões.

De forma geral, os resultados apontaram para um alto grau de homogeneidade entre os conselheiros entrevistados.

Verificou-se que o perfil sócio-demográfico dos conselheiros do segmento da sociedade civil não tem correspondência com as características da maior parte da população a ser representada nesses fóruns porque os conselheiros presentes nos Conselhos têm melhores condições sócioeconômicas.

Identificou-se que a representação vinculada a entidades e/ou associações está presente nos Conselhos Municipais, entretanto, essa 
vinculação é precariamente estabelecida nos Conselhos Gestores Locais da área de saúde. A partir da análise das entidades e/ou associações presentes nos Conselhos Municipais e as relações que indicaram manter com outras, constatou-se potencialidade quanto à existência de redes entre associações que partilham mesma área de atuação e têm objetivos comuns.

Destacam-se como aspectos problemáticos: a parcial representatividade dos Conselhos, o não cumprimento de seu caráter deliberativo e a formação precária dos conselheiros para o exercício de suas atribuições.

PALAVRAS-CHAVE: participação social; conselhos; políticas públicas; promoção da saúde. 
ABSTRACT 



\section{ABSTRACT}

Public Policy Managing Councils in the City of São Paulo: identity, limitations and potentialities under the perspective of Health Promotion

The Public Policy Managing Councils are formalized and institutionalized fora of social participation, established as from the Federal Constitution of 1988. They were created as participation canals and indicate presence and work of social movements and other civil society organizations. The study of these participatory arenas has been indicated, based on the assumption that participation in such fora can foster a virtuous circle, from mobilization and commitment of citizens to strengthening of democracy, thus leading to development of a civic culture.

The conceptual mark of Health Promotion also serves as a reference to discuss public policies that result in better health conditions of the population, due to its assumptions of intersectoral action and social participation.

A study was conducted on the participatory forums characterizing different municipal levels of public policy management in Sao Paulo: Municipal Councils of Environment and Sustainable Development, of Health and Food and Nutritional Safety; and, at local level, at the Managing Councils of Health Technical Supervisions in São Miguel Paulista, Ermelino Matarazzo and Vila Mariana. The objectives were to identify the sociodemographic profile of their members; to identify the associations and/or organizations the members belong to; to characterize and analyze the profile of associations and/or organizations the members of the above mentioned Councils belong to, as well as the relations among them, and to identify the perception of members as to possible articulation and integration of the councils in formulation of intersectoral public policies.

Data collection was performed by a survey of documents, individual interviews with $30 \%$ of the council members of six Councils studied and observation of meetings.

By and large the results indicate high homogeneity among all council members.

The sociodemographic profile of council members of the civil society segment has no correspondence with the characteristics of most of the population to be represented in these forums since they have better socioeconomic conditions.

It was observed that representation related to organizations and/or associations is present at the Municipal Councils; however this link is poorly established at the Local Health Managing Councils. Based on the analysis of organizations and/or associations present at Municipal Councils and the relations they maintain with others, potential networks 
of associations sharing the same field and objectives was identified.

The problematic aspects that stood out are partial representativeness of Councils, no fulfillment of its deliberative character and insufficient training of council members to perform their attributions.

KEYWORDS: social participation; councils; public policies; health promotion. 
ÍNDICE 

ÍNDICE

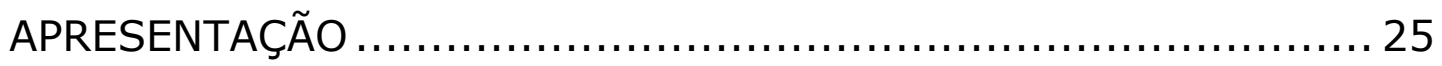

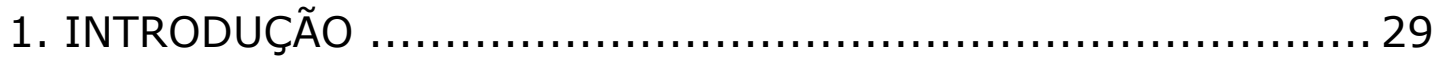

1.1 OS CONSELHOS GESTORES DE POLÍTICAS PÚBLICAS

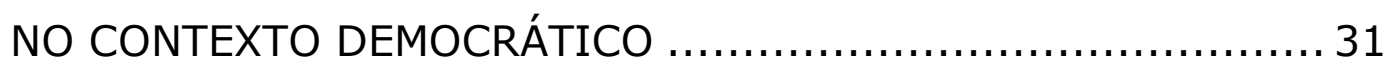

1.2 O PROCESSO DE PRODUÇÃO DE POLÍTICAS PÚBLICAS .... 39

1.3 PROMOÇÃO DA SAÚDE, POLÍTICAS PÚBLICAS E PARTICIPAÇÃO SOCIAL.............................................. 41

1.4 A CRIAÇÃO DOS CONSELHOS GESTORES NO

MUNICÍPIO DE SÃO PAULO .................................... 45

Conselho Municipal do Meio Ambiente e Desenvolvimento



Conselho Municipal de Saúde .................................. 48

Conselho Municipal de Segurança Alimentar e Nutricional ......50 50

Conselhos Gestores de Saúde de nível local ...................... 51

1.5 ASSOCIATIVISMO E INSTÂNCIAS PARTICIPATIVAS .........55

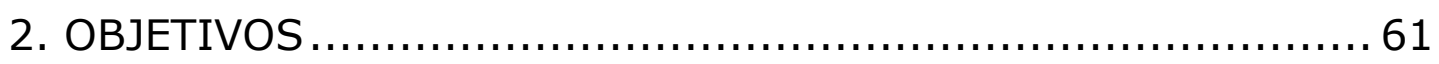

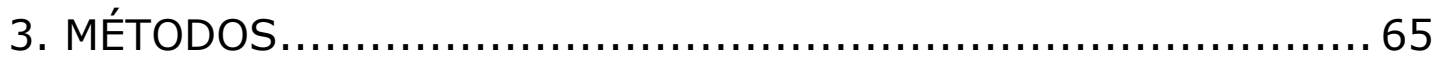

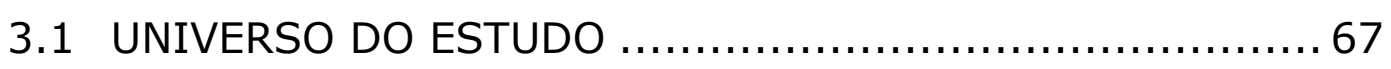

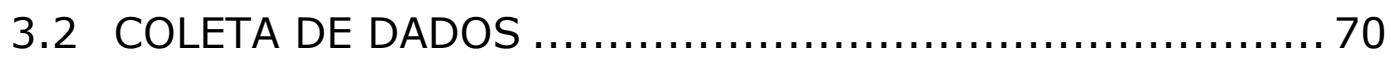

3.3 ANÁLISE DOS DADOS..................................... 75

3.4 ASPECTOS ÉTICOS .......................................... 77

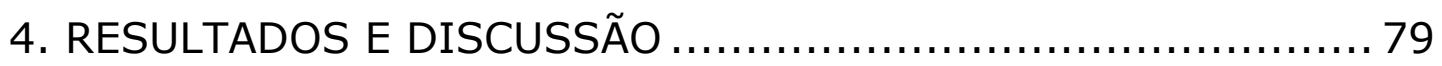

4.1 OS CONSELHOS MUNICIPAIS - MEIO AMBIENTE E DESENVOLVIMENTO SUSTENTÁVEL, SAÚDE E SEGURANÇA

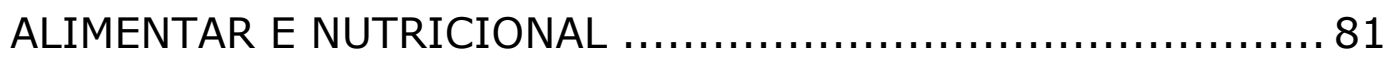

Composição, organização e infra-estrutura ....................... 81

Perfil sócio-demográfico dos conselheiros ......................... 85

As entidades representadas ................................... 91 
Participação e políticas públicas

4.2 OS CONSELHOS GESTORES DAS SUPERVISÕES

TÉCNICAS DE SAÚDE - SÃO MIGUEL PAULISTA, ERMELINO

MATARAZZO E VILA MARIANA

Composição, organização e infra-estrutura ..................... 122

Perfil sócio-demográfico dos conselheiros ...................... 147

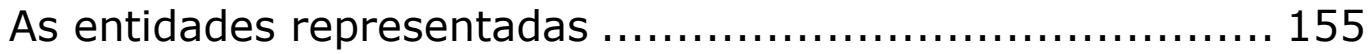

Participação e políticas públicas ................................... 160

4.3 ANÁLISE DE AGRUPAMENTO JUNTO AOS CONSELHOS

MUNICIPAIS E CONSELHOS GESTORES ESTUDADOS ............ 166

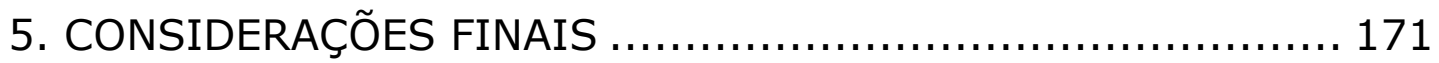

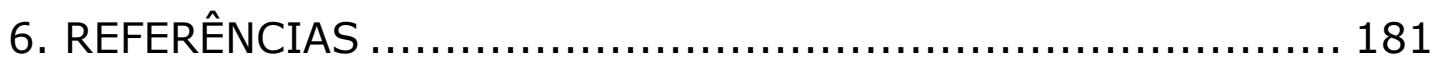

7. ANEXOS .......................................................... 193

ANEXO 1 - Gráfico de dispersão com os Distritos que

compõem cada Subprefeitura do município de São Paulo e seus respectivos Índices de Exclusão Social (IEX), São

Paulo, 2006 e 2007.

ANEXO 2 - Roteiro estruturado para entrevista com

conselheiros dos conselhos Municipais e Conselhos Gestores

das Supervisões Técnicas de Saúde do município de São

Paulo.

ANEXO 3 - Roteiro para observação das reuniões dos

Conselhos Gestores das Supervisões Técnicas de Saúde. ...... 205

ANEXO 4 - Composição do Conselho Municipal do Meio

Ambiente e Desenvolvimento Sustentável de São Paulo

(CADES).

ANEXO 5 - Composição do Conselho Municipal de Saúde de

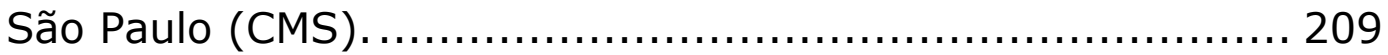

ANEXO 6 - Composição do Conselho Municipal de Segurança

Alimentar e Nutricional de São Paulo (COMUSAN). 
ANEXO 7 - Roteiro estruturado para entrevista com responsáveis técnicos pelos Conselhos Gestores das Supervisões Técnicas de Saúde.

ANEXO 8 - Parecer do Comitê de Ética em Pesquisa da

Faculdade de Saúde Publica da USP.

ANEXO 9 - Parecer do Comitê de Ética em Pesquisa da Secretaria Municipal de Saúde de São Paulo.

ANEXO 10 - Termo de consentimento livre e esclarecido

para os participantes do Projeto Conselhos Municipais: possíveis contribuições para políticas públicas saudáveis na perspectiva da promoção da saúde.

\section{LISTA DE QUADROS}

Quadro 1 - Entidades e/ou associações representadas pelos conselheiros entrevistados no Conselho Municipal do Meio Ambiente e Desenvolvimento Sustentável (CADES), Conselho Municipal de Saúde (CMS) e Conselho Municipal de Segurança Alimentar e Nutricional (COMUSAN), São Paulo, 2006 e 2007.... 92 Quadro 2 - Entidades e/ou associações representadas pelos conselheiros entrevistados no Conselho Gestor da Supervisão Técnica de Saúde de Ermelino Matarazzo, São Paulo, 2006 e 2007.

\section{LISTA DE FIGURAS}

Figura 1 - Cobertura de entrevistas realizadas junto ao Conselho Municipal do Meio Ambiente e Desenvolvimento Sustentável (CADES), Conselho Municipal de Saúde (CMS) e Conselho Municipal de Segurança Alimentar e Nutricional (COMUSAN) e Conselhos das Supervisões Técnicas de Saúde 
de São Miguel Paulista, Ermelino Matarazzo e Vila Mariana, por segmento, São Paulo, 2006 e 2007.

Figura 2 - Distribuição dos temas presentes nas reuniões do Conselho Municipal do Meio Ambiente e Desenvolvimento Sustentável (CADES), Conselho Municipal de Saúde (CMS) e Conselho Municipal de Segurança Alimentar e Nutricional (COMUSAN), São Paulo, 2006 e 2007.

Figura 3 - Perfil sócio-demográfico dos conselheiros entrevistados do Conselho Municipal do Meio Ambiente e Desenvolvimento Sustentável (CADES), segundo segmento, São Paulo, 2006 e 2007

Figura 4 - Perfil sócio-demográfico dos conselheiros

entrevistados do Conselho Municipal de Saúde (CMS), segundo segmento, São Paulo, 2006 e 2007.

Figura 5 - Perfil sócio-demográfico dos conselheiros entrevistados do Conselho Municipal de Segurança Alimentar e Nutricional (COMUSAN), segundo segmento, São Paulo, 2006 e 2007.

Figura 6 - Caracterização das entidades e/ou associações representadas pelos conselheiros entrevistados no Conselho Municipal do Meio Ambiente e Desenvolvimento Sustentável (CADES), São Paulo, 2006 e 2007.

Figura 7 - Relações estabelecidas entre as entidades presentes no Conselho Municipal do Meio Ambiente e Desenvolvimento Sustentável e outras entidades e/ou associações, São Paulo, 2006 e 2007.

Figura 8 - Caracterização das entidades e/ou associações representadas pelos conselheiros entrevistados no Conselho Municipal de Saúde (CMS), São Paulo, 2006 e 2007. 
Figura 9 - Relações estabelecidas entre as entidades presentes no Conselho Municipal de Saúde e outras entidades e/ou associações, São Paulo, 2006 e 2007

Figura 10 - Caracterização das entidades e/ou associações representadas pelos conselheiros entrevistados no Conselho Municipal de Segurança Alimentar e Nutricional (COMUSAN), São Paulo, 2006 e 2007

Figura 11 - Relações estabelecidas entre as entidades presentes no Conselho Municipal de Segurança Alimentar e Nutricional e outras entidades e/ou associações

Figura 12 - Distribuição das entidades e/ou associações representadas pelos conselheiros entrevistados no Conselho Municipal do Meio Ambiente e Desenvolvimento Sustentável (CADES), do Conselho Municipal de Saúde (CMS) e Conselho Municipal de Segurança Alimentar e Nutricional (COMUSAN) e em todos os Conselhos Municipais, segundo área de atuação e objetivos principais, São Paulo, 2006 e 2007.

Figura 13 - Distribuição da percepção dos conselheiros entrevistados do Conselho Municipal do Meio Ambiente e Desenvolvimento Sustentável (CADES), do Conselho Municipal de Saúde (CMS) e Conselho Municipal de Segurança Alimentar e Nutricional (COMUSAN) quanto à influência do Conselho na formulação e implantação de políticas públicas, segundo segmento, São Paulo, 2006 e 2007. 109

Figura 14 - Distribuição da percepção dos conselheiros entrevistados do Conselho Municipal do Meio Ambiente e Desenvolvimento Sustentável (CADES), do Conselho Municipal de Saúde (CMS) e Conselho Municipal de Segurança Alimentar e Nutricional (COMUSAN) quanto à forma de influência do 
Conselho na formulação e implantação de políticas públicas, segundo segmento, São Paulo, 2006 e $2007 . . . \ldots \ldots \ldots \ldots \ldots \ldots \ldots . . . . . . . . .110$ Figura 15 - Distribuição do conhecimento dos conselheiros entrevistados do Conselho Municipal do Meio Ambiente e Desenvolvimento Sustentável (CADES), do Conselho Municipal de Saúde (CMS) e Conselho Municipal de Segurança Alimentar e Nutricional (COMUSAN) sobre o funcionamento de outros conselhos gestores, segundo segmento, São Paulo, 2006 e 2007.

Figura 16 - Distribuição da percepção dos conselheiros entrevistados do Conselho Municipal do Meio Ambiente e Desenvolvimento Sustentável (CADES), do Conselho Municipal de Saúde (CMS) e Conselho Municipal de Segurança Alimentar e Nutricional (COMUSAN) quanto à influência do Conselho na formulação e implantação de políticas públicas integradas e intersetoriais, segundo segmento, São Paulo, 2006 e 2007.

Figura 17 - Distribuição da percepção dos conselheiros entrevistados dos Conselhos Municipais quanto à influência do Conselho na formulação e implantação de políticas públicas integradas e intersetoriais, São Paulo, 2006 e 2007.

Figura 18 - Distribuição da percepção dos conselheiros entrevistados do Conselho Municipal do Meio Ambiente e Desenvolvimento Sustentável (CADES) quanto à existência de políticas intersetoriais e como foram formuladas e implantadas, segundo segmento, São Paulo, 2006 e 2007

Figura 19 - Distribuição da percepção dos conselheiros entrevistados do Conselho Municipal de Saúde (CMS) quanto à existência de políticas intersetoriais e como foram formuladas e implantadas, segundo segmento, São Paulo, 2006 e 2007.... 119 
Figura 20 - Distribuição da percepção dos conselheiros entrevistados do Conselho Municipal de Segurança Alimentar e Nutricional (COMUSAN) quanto à existência de políticas intersetoriais e como foram formuladas e implantadas, segundo segmento, São Paulo, 2006 e 2007.

Figura 21 - Perfil sócio-demográfico dos conselheiros entrevistados do Conselho Gestor da Supervisão Técnica de Saúde de São Miguel Paulista, segundo segmento, São Paulo, 2006 e 2007 148

Figura 22 - Perfil sócio-demográfico dos conselheiros entrevistados do Conselho Gestor da Supervisão Técnica de Saúde de Ermelino Matarazzo, segundo segmento, São Paulo, 2006 e 2007 150

Figura 23 - Perfil sócio-demográfico dos conselheiros entrevistados do Conselho Gestor da Supervisão Técnica de Saúde de Vila Mariana, segundo segmento, São Paulo, 2006 e 2007.

Figura 24 - Distribuição da percepção dos conselheiros entrevistados dos Conselhos Gestores das Supervisões Técnicas de Saúde quanto à influência e quanto à forma de influência do Conselho na formulação e implantação de políticas públicas, segundo segmento, São Paulo, 2006 e 2007. 161 Figura 25 - Distribuição do conhecimento dos conselheiros entrevistados dos Conselhos Gestores das Supervisões Técnicas de Saúde sobre o funcionamento de outros conselhos gestores, segundo segmento, São Paulo, 2006 e 2007 162 Figura 26 - Distribuição da percepção dos conselheiros entrevistados dos Conselhos Gestores das Supervisões Técnicas de Saúde quanto à influência do Conselho na 
formulação e implantação de políticas públicas integradas e intersetoriais, segundo segmento, São Paulo, 2006 e 2007. 162 Figura 27 - Distribuição da percepção dos conselheiros entrevistados dos Conselhos Gestores das Supervisões Técnicas de Saúde quanto à existência de políticas intersetoriais e como foram formuladas e implantadas, segundo segmento, São Paulo, 2006 e 2007 .

Figura 28 - Representação dos Agrupamentos encontrados na primeira análise de agrupamento dos Conselhos Municipais e Conselhos Gestores das Supervisões Técnicas de Saúde, São Paulo, 2006 e 2007.

Figura 29 - Representação dos Agrupamentos encontrados na segunda análise de agrupamento dos Conselhos Municipais e Conselhos Gestores das Supervisões Técnicas de Saúde, São Paulo, 2006 e 2007. 


\section{APRESENTAÇÃO}

Na época, eu não entendi como a luz Ultrapassava o vitral sem quebrá-lo.

Hoje sei o quanto a luz Se estilhaçava na passagem.

Biografia de uma árvore - Fabrício Carpinejar 



\section{APRESENTAÇÃO}

Este trabalho insere-se na linha de pesquisa Promoção da Saúde do Departamento de Prática de Saúde Pública da Faculdade de Saúde Pública da Universidade de São Paulo. Esta linha de pesquisa propõe-se a estudar os processos de fortalecimento e capacitação de indivíduos e coletividades para ampliar suas possibilidades de controlar os condicionantes de saúde-doença e ensejar mudanças significativas no panorama da saúde individual e coletiva. Considerando o objeto de estudo da tese aqui apresentada - conselhos gestores de políticas públicas, seus membros e associações e/ou entidades presentes - o trabalho relaciona-se com as sub-linhas de investigação promoção da saúde e instituições e promoção da saúde e políticas públicas saudáveis.

Especificamente, a temática da participação social, associada com a democratização das relações e o exercício da cidadania, tem permeado grande parte da minha atuação acadêmica nas áreas de ensino, pesquisa e extensão.

$\mathrm{Na}$ Dissertação de Mestrado investiguei a questão da participação social em saúde na perspectiva dos profissionais de saúde. Na Tese de Doutorado estudei as repercussões de uma prática educativa desenvolvida para formar e capacitar pessoas para serem conselheiros de saúde.

Posteriormente, participei de projetos de pesquisa e de intervenção voltados para o incremento e para o aprimoramento de processos participativos no âmbito das políticas públicas.

Além do envolvimento com tais atividades, muitos dos estudantes sob minha orientação, nos programas de iniciação 
científica e pós-graduação, têm privilegiado em seus estudos a questão da participação em diversos contextos e sob diferentes perspectivas. Isso tem permitido criar um espaço de aprendizado e reflexão interessante e produtivo.

O Projeto Conselhos Municipais: possíveis contribuições para políticas públicas saudáveis na perspectiva da promoção da saúde, que deu origem a esta tese, propôs-se a estudar a articulação entre a questão da participação social institucionalizada e os processos decisórios no campo das políticas públicas das áreas sociais. Sua abrangência - três conselhos municipais e três conselhos locais de saúde - permitiu traçar um panorama preliminar quanto à identidade, às limitações e às potencialidades dessas duas instâncias de fóruns participativos, ainda que sem pretensões de generalização. A partir dessa visão mais panorâmica, futuras investigações poderão ser desenhadas com o objetivo de aprofundar aspectos que permitam compreender melhor as características encontradas.

No capítulo da Introdução, o problema da pesquisa conselhos gestores de políticas públicas - é apresentado e são abordadas as temáticas relacionadas e pertinentes ao estudo produção de políticas públicas, promoção da saúde, participação social e associativismo.

Nos capítulos dois e três são descritos os objetivos e a metodologia utilizada no estudo. A seguir, com a pretensão de tornar o texto mais dinâmico e interessante, os resultados são apresentados e discutidos conjuntamente. No último capítulo Considerações Finais - são destacados os achados mais relevantes, em termos de potencialidades, limitações e perspectivas de atuação. 
1. INTRODUÇÃO

Vamos precisar de todo mundo. Um mais um é sempre mais que dois P'rá melhor juntar as nossas forças.

O sal da terra - Beto Guedes e Ronaldo Bastos 



\section{INTRODUÇÃO}

\subsection{OS CONSELHOS GESTORES DE POLÍTICAS PÚBLICAS NO CONTEXTO DEMOCRÁTICO}

Como decorrência das reivindicações de participação da sociedade, ocorridas nas três décadas anteriores, a Constituição brasileira, promulgada em 1988, permitiu a criação de vários conselhos gestores de políticas sociais, desde o nível municipal até o nível federal, o que nunca havia sido presenciado na sociedade brasileira.

Além de responder às demandas dos movimentos sociais, a indicação da possibilidade de existência de conselhos, enquanto mecanismos e instrumentos de participação social, permitiria a efetividade de canais de comunicação e interlocução, procurando superar o descrédito da população brasileira, em geral, com a política e com organizações de representação (FERREIRA, 1999; GERSCHMAN, 2004; BAQUERO, 2009).

No contexto histórico em que se deu a promulgação da Constituição de 1988, período de redemocratização brasileira, a incorporação dos conselhos como instâncias e fóruns para discussão, elaboração e implementação de políticas públicas sociais universalistas foi impulsionado por fatores internos e externos ao próprio Estado, refletiu um processo de caráter nacional e foi resultado de "indução legal e administrativa, gerada em um contexto político de um projeto de remodelagem institucional do Estado visando, via descentralização e participação, habilitá-lo para 
a implementação de políticas sociais universalistas" (CARVALHO, 1998 , p. 24). Assumiu-se a necessidade de uma reforma do Estado, no sentido de adequá-lo ao seu caráter público. Assim, os 'conselhos' espelham o próprio desenho e os limites da política nacional e, também contém, em si, um potencial transformador tanto do Estado, quanto da sociedade.

O surgimento de mecanismos participativos nas democracias liberais ocidentais pode ser creditado tanto à desilusão dos cidadãos com as instituições políticas, quanto ao crescimento de novos movimentos sociais. Esses dois fatores combinaram-se, compondo uma situação de pressão de vários segmentos sociais dirigida às instâncias de governo. Ao mesmo tempo, somada às recomendações das agências internacionais quanto à participação da comunidade nos projetos de desenvolvimento, a crise econômica mundial acabou por impulsionar muitos governos a promoverem reformas com o objetivo de racionalizar as estruturas burocráticas estatais e criar mecanismos de participação social com o objetivo de fiscalizar ações governamentais (CÔRTES, 1996).

É importante referir que o grau de força e mobilização dos movimentos sociais ligados aos setores contemplados com a criação de conselhos gestores era, e ainda é, bastante diferenciado. Destaque-se a situação do setor saúde que teve, nas décadas de 1970 e 1980, expressiva atuação política, o que fez com que representasse uma vanguarda na disputa por espaços participativos (BÓGUS, 1998).

O controle social que se espera que os conselhos gestores exerçam refere-se não ao controle social do Estado para manter a ordem e a coesão social, mas sim ao controle da sociedade sobre os sistemas públicos aos quais estejam vinculados, no sentido de 
ação efetiva da sociedade sobre as ações do Estado. ASSIS e VILLA (2003) indicam que, no caso do setor saúde, para isso é necessário uma política de informação que garanta comunicação suficiente e adequada. É possível considerar isso como pertinente e adequado também para os outros setores ligados às políticas sociais.

Os conselhos gestores de políticas públicas referem-se aqueles ligados às políticas públicas mais estruturadas ou concretizadas em sistemas nacionais, previstos em legislação nacional, com caráter obrigatório ou não. Foram concebidos como fóruns públicos de captação de demandas e negociação de interesses específicos dos grupos sociais e como forma de ampliar a participação dos segmentos com menos acesso ao aparelho do Estado (TATAGIBA, 2002).

A constituição dos fóruns públicos, tais como indicados na criação dos conselhos gestores, corresponde à uma valorização da idéia de participação cidadã que está, por sua vez, fortemente determinada pela teoria de democracia adotada como marco de referência nas reflexões sobre a temática (UGARTE, 2004).

De acordo com NOBRE (2004) é ampla a aceitação da democracia como a melhor possibilidade de regime político e de forma de estabelecer a relação entre Estado e sociedade civil. E, considerando a afirmação de TOURAINE (1996) de que a democracia é a organização institucional das relações entre sujeitos: "é na e pela democracia que o outro pode ser reconhecido como sujeito" (p. 262), os espaços de consulta, participação e deliberação, como os conselhos de políticas públicas, podem representar novas formas de participação que possibilitam o real exercício de reconhecimento e diálogo com o outro e sua cultura e seus valores. 
Retomando a análise desenvolvida por NOBRE (2004), uma das questões centrais quanto ao sentido atualmente atribuído à democracia tem a ver com a definição da natureza e da posição que devem ocupar a participação e a deliberação dos cidadãos no Estado Democrático de Direito. Segundo esse autor, isso corresponde a uma das duas arenas existentes na disputa política em torno do sentido de democracia:

uma em torno das macroestruturas que definem o quadro institucional mais abrangente do regime democrático - eleições periódicas e livres, separação de poderes, regime de governo, respeito a direitos e garantias individuais, etc $(. .$.$) e outra que diz$ respeito à criação de novos espaços de participação e deliberação que desafiam as macroestruturas de um regime democrático, tanto no sentido de desafiar sua capacidade de dar guarida a essas novas formas de participação, como no sentido de, em determinados momentos, colocar em xeque a lógica mesma do arranjo macroestrutural em vigor (NOBRE, 2004, p. 21 - 22).

As idéias vinculadas a novos espaços de participação e deliberação procuram recuperar o papel da mobilização social e da ação coletiva na construção democrática, em oposição ao que foi hegemônico desde o final do século XVIII, em especial na segunda metade do século XX, após a II Guerra Mundial, e que correspondeu à supervalorização do papel dos mecanismos de representação sem que fossem combinados com outros mecanismos de participação (MENDES, 2007; AVRITZER, 2009).

Os aspectos de fragmentação, complexidade e interdependência existentes nas sociedades atuais e a conseqüente complexidade de níveis e instâncias entre os cidadãos e os poderes executivos causam distanciamentos e, em geral, alienam as pessoas da vida política e do acompanhamento dos processos decisórios. Tal situação é um indicador da necessidade de conciliar a democracia representativa com novas formas de democracia participativa, impulsionando a participação descentralizada (mais 
próxima do nível local, onde estão os cidadãos e suas formas de organização como entidades e associações) em tentativa de instalar processos de tomada de decisão de baixo para cima bottom up - (ETCHEVERRY, 2008).

Um dos aspectos que tem sido apontado como possível empecilho para o avanço da democracia participativa são os custos envolvidos nos processos de mobilização e consulta coletivas. Nesse sentido, os conselhos gestores locais de políticas sociais podem ser alternativas interessantes, de acordo com COELHO (2004).

Além disso, o estabelecimento de instâncias de democracia semidireta ou participativa pela Constituição brasileira de 1988 e respectiva legislação complementar também ganha importância pela maior possibilidade de controle sobre os representantes e pela possibilidade de proposição e elaboração de políticas públicas. Vários instrumentos e mecanismos viabilizam 'deliberações públicas': plebiscito, referendo popular, conselhos gestores e outros (MENDES, 2007).

O que dá sustentação à criação desses mecanismos é o argumento de que a 'representação' tem se mostrado insuficiente e não pode ser o único instrumento a apoiar a democracia moderna e que a incorporação ou combinação de pressupostos da democracia direta no interior da democracia representativa aprimora-a, na medida em que inclui setores excluídos do campo político, além de cumprir uma função educativa porque é por meio do próprio exercício da participação que o cidadão aprende o que é democracia (LUCHMANN, 2007; 2008; WENDHAUSEN, 2007).

WENDHAUSEN (2007) refere os trabalhos de Patemann e Bobbio para defender uma combinação entre elementos da democracia representativa e da democracia direta, advogando uma 
forma intermediária, no sentido de que nenhuma delas é suficiente em si mesma, mas podem ser complementares, permitindo aprimoramento dos processos decisórios que têm lugar, por exemplo, nos conselhos gestores. Os conselhos gestores seriam espaços de combinação de instâncias representativas com participação direta, pois são ocupados por representantes eleitos ou indicados, mas que estariam mais próximos de suas bases.

Aí se tem também a defesa de uma política deliberativa que ocorreria em espaços tais como conselhos, associações civis, orçamentos participativos, idealmente por meio de debates e discussões em torno de idéias, o que também cumpriria um papel pedagógico de desenvolvimento de cidadania, por meio de capacitação individual e coletiva (CÔRTES,2005; MENDES, 2007; LUCHMANN, 2007).

Vale destacar novamente que a idéia dos conselhos gestores originou-se na área da saúde, a partir da atuação dos movimentos sociais para os quais convergiram as organizações populares e os profissionais de saúde pública (BÓGUS, 1998). A proposta de institucionalização de conselhos com representação paritária veio da preocupação de que os representantes governamentais não dominassem as discussões e decisões nesses espaços. Para os militantes e ativistas dos movimentos sociais, interessados em reivindicar direitos e propor políticas, a garantia da representação paritária significou avanços, pois tornaria mais inclusivo e participativo o processo de formulação de políticas (ABERS e KECK, 2008), reforçando-se também a participação social como uma prioridade para a construção da capacidade da comunidade para analisar e priorizar suas necessidades, formular e negociar suas propostas.

Esse período de implementação de novas instituições 
participativas de produção de políticas como os conselhos gestores correspondeu, segundo análise de WAMPLER e AVRITZER (2004), ao terceiro estágio de desenvolvimento dos públicos participativos - "que compreende cidadãos organizados que buscam superar a exclusão social e política por meio de deliberação pública, promoção de transparência e responsabilização e da implementação de suas preferências políticas" (p. 215) -, o que, conforme já referido, teve início durante a Assembléia Constituinte nos anos de 1987 e 1988. Os estágios anteriores corresponderam ao final da década de 1970 e início da década de 1980 quando atores e organizações buscaram aprofundar a democracia por meio de reivindicações de direitos de cidadania: houve a proliferação de associações comunitárias e voluntárias e uma explosão de 'participação' especialmente nos centros urbanos. Em seguida, os públicos participativos começaram a ter uma atuação que colocava em xeque a tradição clientelista e hierárquica existente no país e criaram oportunidades para os atores sociais experimentarem novas estratégias organizacionais no âmbito de seus movimentos.

Dessa forma, é possível destacar a criação dos conselhos gestores de políticas, ocorrida a partir dos anos de 1980, como uma das principais inovações institucionais do processo de redemocratização do Brasil.

Paralelamente e conjuntamente ao estabelecimento de instâncias de participação direta, deu-se processo de descentralização das políticas públicas reforçado com a instituição de fundos orçamentários e o privilegiamento de planos de atenção local para o enfrentamento dos principais problemas sociais vivenciados pela maior parte da população brasileira. Há um entendimento de que esses dois processos se complementam no 
sentido de que aproximam a reflexão sobre os problemas do nível local, onde são sentidos e têm que ser solucionados, de processos decisórios mais participativos, além de poderem avançar quanto às articulações entre as políticas setoriais, promovendo intersetorialidade, ainda que incipiente, na maior parte das vezes (COMERLATTO e col., 2007).

Um outro aspecto vinculado à atuação dos conselhos gestores refere-se às repercussões que a existência desse canal de comunicação entre a sociedade civil e o poder executivo local possa, supostamente, melhorar o rendimento da gestão do Estado ao ampliar a capacidade do sistema para implementar ações que beneficiariam a estabilidade governamental (LUCAMBO e COUTINHO, 2004; ETCHEVERRY, 2008).

Participação e deliberação, de acordo com COELHO e NOBRE (2004, p. 11) "aparecem hoje no centro de um grande debate sobre a renovação da democracia, sendo que a experiência brasileira nesta área, por sua dimensão e vitalidade, ganhou um lugar de destaque no cenário internacional". A variedade de experiências vividas no período de redemocratização e o volume de público participante, chamam a atenção e aquecem o debate sobre o potencial democrático destas experiências. Trata-se de abordar a participação e o fortalecimento de práticas políticas e de constituição de direitos que vão além dos processos eleitorais, com a criação de canais de comunicação com a sociedade e com a ampliação das esferas de engajamento dos cidadãos (JACOBI, 2000). 


\subsection{O PROCESSO DE PRODUÇÃO DE POLÍTICAS PÚBLICAS}

Uma das expectativas em torno das instâncias participativas, tais como os conselhos gestores, refere-se às possíveis influências e interferências quanto à produção de políticas públicas, o que já é, em si, um processo complexo e que envolve várias etapas: proposição, elaboração, implantação, implementação e avaliação. À essa complexidade, somam-se as questões relativas à organização e funcionamento desses fóruns participativos, além da pouca tradição brasileira quanto à clareza e transparência dos processos decisórios de interesse público.

Há um razoável consenso entre autores dessa área de que, tanto o campo da política pública, em geral, quanto da política social, em particular, são campos multidisciplinares. Suas definições têm embutido uma visão holística do tema, no sentido de que o 'todo' de que tratam é mais importante do que a soma das 'partes' que o compõem e que são vários os fatores que contam na sua definição - indivíduos, instituições, ideologias, interesses -, mesmo que com pesos diferentes em cada situação (SOUZA, 2006).

Uma política pública é um conjunto de ações ou omissões por parte dos governos que influencia a vida dos cidadãos. A ação pode ser direta ou por meio de delegação e corresponde a uma resposta para uma questão que desperta a atenção, o interesse ou a mobilização de atores da sociedade civil (SOUZA, 2006; LABRA, 2009).

As políticas públicas são, então, desenhadas no marco de procedimentos e instituições governamentais, legitimadas por legislações ou regulações; pretendem promover mudanças no comportamento de indivíduos, grupos sociais e instituições, 
expressam uma visão de sociedade e, a rigor, devem refletir um interesse público (SACARDO, 2004).

Dos estudos que fazem revisões de literatura sobre as principais vertentes analíticas relacionadas à temática das políticas públicas vale destacar, considerando o objeto deste trabalho, a perspectiva do neo-institucionalismo que enfatiza a importância das instituições e suas regras formais e informais para a decisão, formulação e implementação de políticas públicas, além dos atores sociais (indivíduos ou grupos) que têm força relevante na representação de seus interesses. Isso é importante porque dá a devida importância tanto para as instituições políticas e econômicas que mediam a disputa de poder entre os grupos sociais em torno de políticas públicas, como também para os interesses, para as idéias e para a história (LABRA, 1999; FARIA, 2003; SOUZA, 2006).

$\mathrm{Na}$ atualidade, considerando o contexto mundial de globalização que afeta a maior parte das temáticas relacionadas com as políticas governamentais voltadas para as populações, de acordo com FARIA (2003), o processo de produção de políticas é resultado das relações que se estabelecem entre políticos, burocratas, grupos de interesse, mercados financeiros globais e as instituições financeiras internacionais e os atores não governamentais de atuação transnacional.

Outro aspecto de fundamental importância é não perder de vista todo o ciclo a que corresponde a produção de políticas públicas. Em geral, as atenções se concentram na fase de formulação da política e as fases de implementação e monitoramento são deixadas de lado. Isso ocorre, inclusive, no caso da atuação dos conselhos ou das outras formas de experiências participativas, em decorrência de inúmeras 
dificuldades e da falta de instrumentos para o seguimento das ações.

Uma das razões para isso é certa ruptura que há no processo de produção das políticas: na fase inicial, que corresponde à formulação, há bastante politização em torno do tema ou problema que, em alguma medida, causa inquietação a algum grupo e/ou governo que consegue, no jogo de forças próprio da arena política, incluir a questão na pauta de alguma instância decisória e na agenda governamental; aí há o exame das causas, possíveis soluções e escolha das alternativas de ação e tomada das decisões. Depois disso vem a aprovação e promulgação de legislação devida e, em seguida, a execução ou implementação e aí é que se passa para o campo da 'administração' que tanto se dá no âmbito das agências do poder executivo, quanto do poder legislativo, onde também podem ocorrer disputas e interferências dos atores favoráveis e contrários à política mas, geralmente, distante do olhar dos promotores iniciais da política pública em questão (FARIA, 2003; SOUZA, 2006; LABRA, 2009).

\subsection{PROMOÇÃO DA SAÚDE, POLÍTICAS PÚBLICAS E PARTICIPAÇÃO SOCIAL}

A concepção de saúde como produto social, decorrente de fatores relacionados com a qualidade de vida, padrões adequados de alimentação e nutrição, habitação, saneamento e educação, embasa o paradigma da promoção da saúde. As ações a serem desenvolvidas, com o objetivo de produzir melhorias nas condições de vida e de saúde, devem estar voltadas para a coletividade e para o ambiente, por meio de políticas públicas. 
Assim, é pertinente considerar os princípios norteadores das iniciativas de promoção da saúde - concepção holística, intersetorialidade, empowerment, participação social, eqüidade, ações multi-estratégicas e sustentabilidade (SÍCOLI e NASCIMENTO, 2003) - como referenciais para a elaboração, implantação e implementação de políticas públicas que tenham como meta e compromisso favorecer a proteção e a promoção da saúde; o que significa que são políticas que não se restringem ao setor saúde, mas que procuram dar conta da complexidade dos problemas da atualidade, especialmente dos que ocorrem nas grandes metrópoles. Isso impõe a busca de modos de gestão sustentados na intersetorialidade, integralidade e participação social.

As necessidades sociais apresentam-se de formas múltiplas e exigem intervenções intersetoriais. Ampliar a capacidade de resposta dos setores, diante da magnitude e da complexidade dos problemas da população, é o desafio para uma gestão voltada a essas necessidades sociais. Ou seja, são processos que vão constituir "novas institucionalidades plurais, como espaços de planejamento e implementação de políticas" (SILVEIRA e col., 2002, p.258).

A intersetorialidade deve ser entendida como um processo articulado e integrado de formulação e implementação de políticas públicas. Pressupõe a integração de estruturas, recursos e processos organizacionais e caracteriza-se pela co-responsabilidade dos diferentes setores governamentais, não governamentais e da sociedade civil, no sentido do desenvolvimento humano e da melhoria da qualidade de vida. Implica em maturidade do setor público para realizar, com a participação dos setores governamentais, do empresariado, de organizações não- 
governamentais e da sociedade civil, o diagnóstico de problemas, a identificação de potencialidades e a definição de prioridades (VIANA, 1998).

Nessa perspectiva, as políticas públicas não são iniciativas exclusivas ou de monopólio do aparelho estatal, mas são elaboradas e pactuadas em fóruns participativos, que expressam a diversidade de interesses e necessidades sociais. Com essa concepção, a promoção da saúde prioriza o fortalecimento das organizações comunitárias, redistribuindo recursos relativos à formação e informação para os grupos mais marginalizados dos processos de decisão para que possam se fortalecer e exercer pressão para a abertura de espaços mais permeáveis e democráticos (WESTPHAL, 2007).

KOGA (2003) destaca que

a interdependência das políticas setoriais se faz notar quando se atua a partir de territórios específicos, pois ele registra o mesmo espaço, as mesmas pessoas, a mesma realidade em questão. A totalidade do cotidiano vem à tona e exige da ação governamental ações igualmente totalizantes KOGA (2003, p. 242).

A participação social, conforme apresentada no texto de MOREIRA e colaboradores (2008) -

[...] um conjunto de relações culturais, sociopolíticas e econômicas em que sujeitos, indivíduos ou coletivos, diretamente ou por meio de seus representantes, direcionam seus objetivos para o ciclo de políticas públicas, procurando participar ativamente da discussão orçamentária, formulação, implementação, implantação, execução e avaliação das ações, programas e estratégias que regulam a distribuição dos bens públicos e, por isso, interferem diretamente nos direitos de cada cidadão (MOREIRA e col., 2008, p. 58) -

está intimamente ligada ao empowerment comunitário, definido por CARVALHO (2004)

[...] como um processo, e um resultado, de ações que afetam a distribuição do poder levando a um acúmulo, ou desacúmulo de poder (disempowerment) no âmbito das esferas pessoais, intersubjetivas e políticas. Nesta categoria encontram-se inscritos 
elementos que caracterizam um patamar elevado de empowerment psicológico, a participação ativa na ação política e a conquista de (ou possibilidade de) recursos materiais ou de poder por parte de indivíduos e coletivos (CARVALHO, 2004, p. 1092),

pois a capacitação e o fortalecimento dos indivíduos e grupos sociais e da ação comunitária são importantes para uma participação social efetiva, sem a qual não há transformação social, que é o principal objetivo de uma abordagem crítica da Promoção da Saúde (FERREIRA e CASTIEL, 2009). De acordo com MARCONDES (2004), cabe exatamente à participação social um papel fundamental no comprometimento da promoção da saúde com a luta pela extensão dos direitos da população a uma saúde pública de qualidade.

A participação formalizada nos fóruns institucionalizados, como os Conselhos Gestores, previstos como parte do processo de ampliação de gestões descentralizadas e participativas, delineia-se como exercício dinâmico de negociação e pactuação. De acordo com CARVALHO (2004), esses próprios espaços públicos devem ser espaços de aprendizagem e formação.

A participação social pode ser facilitada por meio de processos educativos politicamente comprometidos com a capacitação dos indivíduos para sua autonomia e emancipação. Isso significa ter como referencial as teorias pedagógicas críticas que buscam romper o círculo vicioso que se estabelece entre a desigualdade social e a desigualdade educativa. A pedagogia crítica vincula o projeto educativo à comunidade em que ele se insere e fundamenta a possibilidade de mudança individual e social em processos educativos baseados na interação (AYUSTE e col., 1994).

Algumas experiências voltadas para a capacitação de conselheiros têm sido bem sucedidas ao se utilizarem de princípios 
da educação popular, tais como: estabelecimento de diálogo entre os sujeitos; educação entendida como processo de humanização; trabalho com a totalidade das dimensões dos sujeitos envolvidos; consideração dos conhecimentos e experiências prévias dos participantes (BÓGUS, 2007; PELICIONI e PELICIONI, 2007). Destaque-se que, no caso da educação, o processo, o procedimento, o caminho escolhido e percorrido para o alcance dos objetivos têm grande importância e, muitas vezes, a eles é atribuído mais valor do que aos próprios resultados.

Da mesma forma, é importante registrar o que pontuam alguns autores: a participação, como princípio da promoção da saúde, tem um fim em si mesmo, enquanto um direito social, em oposição a uma visão exclusivamente utilitarista que advoga pela participação como um meio para alcançar objetivos já definidos nas instituições governamentais ou em outras instâncias de forma não coletiva (VÁZQUEZ e col., 2003).

\subsection{A CRIAÇÃO DOS CONSELHOS GESTORES NO MUNICÍPIO DE SÃO PAULO}

Os dados disponíveis indicam que, até 1999, já tinham sido criados mais de 39.000 conselhos relacionados à área de políticas sociais em todo o país (ABERS e KECK, 2008) e existiam, naquele ano, cerca de 1.167 em funcionamento no Estado de São Paulo (TATAGIBA, 2002) e, até 2004, pelo menos 19 Conselhos 
Municipais ${ }^{1}$ atuantes no município de São Paulo (TATAGIBA, 2004). A consulta ao material disponível no portal virtual da Prefeitura de São Paulo confirmou esses dados ${ }^{2}$.

Os conselhos municipais de São Paulo têm uma história longa, mas descontínua, que reflete a sucessão de princípios éticopolíticos distintos, de acordo com o grupo político detentor do poder executivo (TATAGIBA, 2004).

De forma geral, até a década de 1980, os conselhos municipais instituídos no município, foram utilizados como forma de cooptação das lideranças e manipulação das demandas populares e, em oposição a essa instrumentalização da participação, movimentos sociais organizados passaram a investir, a partir dos anos de 1970 e 1980 em novos e alternativos espaços de participação, por meio da criação dos "Conselhos Populares" (GOHN, 2003a). Nesse contexto, os movimentos ligados à área de saúde desempenharam papel bastante ativo, em especial o Movimento de Saúde da Zona Leste (BÓGUS, 1998).

No final da década de 1980 e início da década de 1990, com a gestão petista no município de São Paulo, houve ampliação dos canais de interlocução governo - sociedade, destacando-se grande expansão de conselhos institucionalizados, em consonância com a

1 Conselho Municipal de Acompanhamento e Controle Social do FUNDEF; Conselho Municipal de Alimentação Escolar; Conselho Municipal de Assistência Social; Conselho Municipal de Cultura; Conselho Municipal dos Direitos da Criança e do Adolescente; Conselho Municipal da Educação; Conselho Municipal de Habitação; Conselho Municipal do Idoso; Conselho Municipal do Meio Ambiente e Desenvolvimento Sustentável; Conselho do Orçamento Participativo; Conselho Municipal da Pessoa Deficiente; Conselho Municipal de Políticas Urbanas; Conselho de Monitoramento da Política de Direitos das Pessoas em Situação de Rua da Cidade de São Paulo; Conselho Municipal de Políticas Públicas de Drogas e Álcool; Conselho Municipal de Saúde; Conselho Municipal de Segurança Alimentar e Nutricional; Conselho Municipal de Trânsito e Transporte; Conselho Municipal de Turismo e Conselhos Tutelares.

2 http://www.capital.sp.gov.br/portalpmsp/homec.jsp, acessado em 29 de maio de 2009. 
Constituição Federal de 1988, que indicou os conselhos de políticas públicas, nos três níveis de governo, como parte da estrutura administrativa do Estado.

\section{Conselho Municipal do Meio Ambiente e Desenvolvimento} Sustentável

O Conselho Municipal do Meio Ambiente e Desenvolvimento Sustentável de São Paulo (CADES) foi criado em 18 de outubro de 1993 pela Lei $\mathrm{n}^{\circ} 11.426$ (PMSP, 1993), durante o mandato do prefeito Paulo Maluf. Trata-se de órgão consultivo e deliberativo em questões referentes à preservação, conservação, defesa, recuperação e melhoria do meio ambiente natural, construído e do trabalho, em todo território do município de São Paulo.

Segundo Calderón, citado por TATAGIBA (2004), a criação do Conselho do Meio Ambiente e Desenvolvimento Sustentável era uma antiga reivindicação dos movimentos ambientalistas. Apesar disso, na época de sua criação as entidades ambientalistas foram muito críticas devido à percepção de que a intenção do poder executivo era, então, apenas uma tentativa de legitimar as "grandes obras" que o prefeito Paulo Maluf realizou durante o seu mandato.

O Conselho é composto por 32 conselheiros titulares e igual número de suplentes, sendo vinte representantes do segmento do governo $(62,5 \%)$, dez conselheiros do segmento da sociedade civil $(31,25 \%)$ e dois conselheiros observadores de órgãos públicos $(6,25 \%)$.

Os conselheiros na qualidade de observadores especiais são indicados pelas respectivas autoridades superiores, bem como seus 
suplentes, e participam das reuniões do Conselho com direito a voz, mas sem direito a voto.

Os representantes dos órgãos da Administração Municipal, bem como seus respectivos suplentes, são designados pelo Prefeito, mediante indicação dos Secretários das áreas. Os representantes do outro segmento são também designados e/ou escolhidos pelo prefeito mediante indicações previamente realizadas pelas entidades que compõem o respectivo segmento. 0 mandato dos conselheiros é de 24 meses.

Para viabilizar o funcionamento do conselho, há a presidência e a coordenação geral, responsáveis pela organização das reuniões ordinárias e extraordinárias. Também podem ser criadas câmaras técnicas e comissões especiais, de acordo com necessidades específicas. As reuniões da plenária são realizadas mensalmente.

\section{Conselho Municipal de Saúde}

O Conselho Municipal de Saúde (CMS) é um órgão de instância máxima colegiada, deliberativa e de natureza permanente. Seus princípios constitucionais consolidam-se nas Leis $\mathrm{n}^{\circ} 8.080$ de 19 de setembro de 1990 (BRASIL, 1990b), que criou o Sistema Único de Saúde (SUS) e $n^{\circ} 8.142$ de 28 de dezembro de 1990 (BRASIL, 1990c), que definiu a participação da comunidade no SUS e no Decreto ${ }^{\circ} 99.438$ de 7 de agosto de 1990 (BRASIL, 1990a), que criou o Conselho Nacional de Saúde, regulamentando a participação social.

O Conselho Municipal de Saúde foi criado em 29 de junho de 1989, por meio da Portaria $n^{\circ} 1.166$ (PMSP, 1989) da Secretaria Municipal de Saúde, durante o governo de Luiza Erundina, ou seja 
ele iniciou seu funcionamento antes da maioria dos 5.463 conselhos municipais de saúde existentes no país que foram criados entre 1991 e 1997. Durante os governos de Paulo Maluf e Celso Pitta, o CMS foi impedido de funcionar. Somente em 7 de janeiro de 1998, por meio da Lei $n^{0} 12.564$ (PMSP, 1998a), foi instituído legalmente, como órgão específico da Secretaria Municipal de Saúde, em conformidade com a Lei Orgânica do Município de São Paulo de 1990, nos termos do seu Artigo 218 e disposições estabelecidas no Decreto $n^{0}$ 37.330/98 (PMSP, 1998b), alterado pelos Decretos $n^{\text {os }} 38.000$ de 1999 (PMSP, 1999a) e 38.576 de 1999 (PMSP, 1999b).

O CMS tem por finalidade atuar e deliberar na formulação e controle da execução da política municipal de saúde, inclusive nos aspectos econômicos e financeiros, nas estratégias e na promoção do processo de controle social em toda a sua amplitude, no âmbito dos setores público e privado.

É composto por 32 membros titulares e mesmo número de suplentes, sendo dezesseis representantes da sociedade civil $(50 \%)$, oito representantes dos trabalhadores $(25 \%)$ e oito representantes do governo (25\%). Os conselheiros representantes dos segmentos da sociedade civil e dos trabalhadores são eleitos em conferências municipais realizadas a cada dois anos e os mandatos são de 24 meses. Os membros do segmento da administração são indicados pelo poder executivo.

As reuniões da plenária são mensais. Há comissões temáticas que se organizam internamente, de acordo com dinâmica própria para a realização de suas tarefas.

O Conselho de Saúde é um dos mais antigos conselhos a descentralizar suas ações por meio da criação dos Conselhos 
Gestores de nível local, distrital e regional (TATAGIBA, 2004).

\section{Conselho Municipal de Segurança Alimentar e Nutricional}

O Conselho Municipal de Segurança Alimentar e Nutricional de São Paulo (COMUSAN) foi criado em 13 de fevereiro de 2003 por meio do Decreto $n^{\circ} 42.862$ (PMSP, 2003) pela prefeita Marta Suplicy. Na época de sua criação era vinculado à Secretaria Municipal de Abastecimento, atualmente é vinculado à Secretaria das Subprefeituras, por meio da Supervisão de Abastecimento. É um órgão apenas consultivo, com o objetivo de contribuir para a concretização do direito humano à alimentação e à segurança alimentar e nutricional.

Era constituído, entre 2006 e 2007, por quarenta membros titulares e igual número de suplentes, sendo dez representantes do governo $(25 \%)$, vinte representantes da sociedade civil organizada (50\%) e dez representantes dos trabalhadores (25\%) do setor de alimentos, por meio de suas respectivas entidades de classes.

Os membros do COMUSAN, representantes da sociedade civil e dos trabalhadores são eleitos e empossados na Conferência Municipal de Segurança Alimentar e Nutricional e os membros do segmento da administração são indicados pelo poder executivo. No período do estudo cada gestão eleita tinha dois anos de mandato.

As reuniões da plenária são mensais, em geral na primeira quinta-feira de cada mês. O Conselho tem uma Comissão Técnica Institucional, composta por representantes do setor público, entidades de classe, sociedade civil organizada e instituições científicas, cujo funcionamento é definido no Regimento Interno do Conselho. 
Com a publicação do Decreto $\mathrm{n}^{0} 50.126$ de 17 de outubro de 2008 (PMSP, 2008), foram homologadas modificações no Regimento Interno do COMUSAN que alteraram a sua composição. o COMUSAN passou a ser formado por 45 membros titulares e igual número de suplentes, com quinze representantes governamentais e trinta representantes da sociedade civil organizada, sendo dez desses representantes de trabalhadores de áreas afins do setor de alimentos, por meio de suas respectivas entidades de classe. Também foi modificado o tempo de mandato de cada gestão, que passou a ser de 36 meses.

\section{Conselhos Gestores de Saúde de nível local}

O surgimento dos denominados, no nível municipal, Conselhos Gestores de Saúde, deu-se com o Decreto $n^{\circ} 38.756$ de 5 de novembro de 1999 (PMSP, 1999b), que dispunha sobre o Conselho Municipal de Saúde, atribuindo-Ihe: "Estabelecer instruções e diretrizes gerais para a formação dos Conselhos Gestores de nível local, distrital, regional e municipal, nos serviços públicos e nos serviços privados, conveniados e contratados" (Inciso XI do Artigo $3^{\circ}$ ). Os Conselhos Gestores foram definidos como instâncias máximas de decisão em seus níveis, responsáveis pela aplicação da política de saúde nas áreas compreendidas por eles.

Já em 2002, a Câmara Municipal elaborou a Lei $n^{0} 13.325$, de 8 de fevereiro (PMSP, 2002a), que instituiu os Conselhos Gestores das Unidades de Saúde vinculadas ao SUS, dando-Ihes caráter deliberativo e permanente. A redação desta lei foi mais específica do que a anterior, dispondo sobre diversos aspectos administrativos, que foram posteriormente complementados por 
meio do Decreto $\mathrm{n}^{\circ}$ 44.658, de 23 de abril de 2004 (PMSP, 2004b).

Seguindo as diretrizes do SUS, foram definidas como atribuições dos Conselhos Gestores, o planejamento, o acompanhamento, a avaliação e a fiscalização dos serviços e ações de saúde, prestados à população, bem como a proposição e a aprovação de medidas para melhor administração e aplicação destes; tomar parte na elaboração e na execução do orçamento e da administração técnica e operacional das respectivas unidades; atender às demandas encaminhadas por pessoas ou entidades; buscar estratégias para integrar o trabalho das unidades de saúde aos planos de saúde local, regional, municipal e estadual; entre outras atividades.

A composição de um conselho gestor de unidade de saúde ${ }^{3}$ é tripartite, com 50\% de representantes de usuários da unidade de saúde, $25 \%$ de trabalhadores da área da saúde (servidores e empregados públicos dos níveis federal, estadual e municipal e, também, trabalhadores terceirizados que atuam dentro da área compreendida pela unidade ou coordenadoria de saúde, com exceção daqueles que estiverem exercendo função de gerenciamento) e $25 \%$ de representantes da direção da unidade, incluindo nessa porcentagem, como membro nato, o diretor da unidade. O número de membros deve ser definido por cada conselho, segundo a demanda da respectiva unidade, no limite mínimo de quatro e máximo de dezesseis membros e igual número de suplentes. Pesquisa feita pela Secretaria Municipal de Saúde

3 Compreende-se como unidade de saúde: "todas as unidades que prestam atendimento à população sob gestão municipal: Hospitais e Prontos-Socorros e Prontos-Atendimentos, Unidades Básicas de Saúde, Hospitais Dia, Centros de Convivência e Cooperativa, Centros de Atenção Psicossocial, Ambulatórios de Especialidades, Centros de Referência e Laboratórios" (Parágrafo $2^{\circ}$ do Artigo $2^{\circ}$ do Decreto $n^{\circ}$ 44.658, de 23 de abril de 2004) (PMSP, 2004b). 
revelou que, em 2004, 75,5\% das unidades de saúde tinham conselho gestor instituído e, em 2005, esse índice passou para $82,4 \%$.

Até o final do ano de 2004, no nível regional, havia os Conselhos das Coordenadorias de Saúde que correspondiam às 31 Subprefeituras do município. Desde janeiro de 2005, esses Conselhos passaram a ser denominados Conselhos Gestores das Supervisões Técnicas de Saúde, em função da criação de cinco Coordenadorias Regionais de Saúde (Centro-Oeste, Leste, Norte, Sudeste e Sul) - instâncias intermediárias entre a Secretaria Municipal de Saúde e as Supervisões Técnicas de Saúde (estas, anteriormente denominadas Coordenadorias de Saúde). Atualmente, existem 25 Supervisões Técnicas de Saúde apesar de serem 31 as Subprefeituras do município de São Paulo, porque algumas Supervisões Técnicas de Saúde correspondem à junção de mais de uma Subprefeitura.

Para os Conselhos Gestores das Supervisões Técnicas de Saúde não há na legislação, citação específica sobre sua composição e funcionamento, uma vez que a legislação publicada mais recentemente dispõe ainda sobre os Conselhos das Coordenadorias de Saúde (Decreto $n^{\circ} 44.568$, de 23 de abril de 2004) (PMSP, 2004b) e a organização em Supervisões Técnicas de Saúde ocorreu no ano de 2005. Para fins de funcionamento, as instâncias administrativas têm considerado que o que está disposto na legislação para os Conselhos das Coordenadorias de Saúde pode ser aplicado aos Conselhos Gestores das Supervisões Técnicas de Saúde, com as demais normas de funcionamento, requisitos para eleições, entre outros aspectos a serem definidos nos Regimentos Internos dos próprios conselhos gestores. Assim, a composição do 
Conselho Gestor da Supervisão Técnica de Saúde é quadripartite, sendo $50 \%$ dos membros do segmento dos usuários, $25 \%$ do segmento dos trabalhadores da área e $25 \%$ do segmento da administração, divididos entre os representantes do poder público e dos prestadores de serviços. O coordenador da Supervisão Técnica de Saúde é membro nato do conselho. O número indicado de membros é 24, com respectivos suplentes.

O tempo de mandato dos conselheiros que compõem os conselhos gestores é de dois anos e não é permitida a remuneração a nenhuma pessoa por exercer a atividade de conselheiro.

As reuniões ordinárias devem acontecer mensalmente, sendo divulgadas e abertas à participação de qualquer pessoa, que terá direito à voz. O quórum mínimo de deliberação para as atividades dos conselhos é de metade mais um. Os membros suplentes, na presença dos respectivos titulares, têm direito à voz, mas não a voto, e na ausência dos titulares, têm direito à voz e voto. Comunicados e resoluções tomadas deverão ser amplamente divulgados nas unidades, de forma a facilitar o acesso dos usuários e interessados às informações.

Fica a cargo de cada conselho gestor elaborar seu Regimento Interno e suas normas de funcionamento, sendo o processo eleitoral desencadeado pelas coordenadorias de saúde, por meio da formação de comissão eleitoral paritária. O coordenador do conselho deverá ser escolhido pelo colegiado dos seus membros.

A garantia da estrutura técnica e administrativa para o funcionamento dos conselhos gestores deve ser dada pelas respectivas unidades e coordenadorias de saúde, autarquias ou fundações. 


\subsection{ASSOCIATIVISMO E INSTÂNCIAS PARTICIPATIVAS}

GOHN (2005) propõe um panorama dos movimentos sociais atuais em torno de eixos temáticos que caracterizam suas lutas e demandas ${ }^{4}$. Embora seja possível localizar em vários desses eixos os conselhos colocados como objeto deste estudo, é no eixo temático da mobilização e organização popular em torno de estruturas institucionais de participação na gestão políticoadministrativa da cidade que aparece, especificamente, a questão dos conselhos gestores setoriais, como um de seus sub-eixos, tais como saúde e educação. Mas, também é possível entender que tais conselhos inserem-se em outros eixos temáticos como movimentos sociais ao redor da questão urbana, movimentos pela educação, movimentos ao redor da questão da saúde e movimentos das cooperativas populares (como a produção alternativa de alimentos).

Com uma preocupação de classificar especificamente os conselhos e não os movimentos ligados a eles, no estudo realizado por TATAGIBA (2002), a autora adotou a denominação proposta pela pesquisa Conselhos Municipais e Políticas Sociais que divide os conselhos em Conselhos de Programas, Conselhos de Políticas e Conselhos Temáticos.

\footnotetext{
${ }^{4}$ Movimentos sociais ao redor da questão urbana, pela inclusão social e por condições de habitabilidade na cidade; mobilização e organização popular em torno de estruturas institucionais de participação na gestão políticaadministrativa da cidade; movimentos pela educação; movimentos ao redor da questão da saúde; movimentos de demanda na área dos direitos; mobilizações e movimentos sindicais contra o desemprego; movimentos decorrentes de questões religiosas de diferentes crenças, seitas e tradições religiosas; movimentos contra as políticas neoliberais; grandes fóruns de mobilização da sociedade civil organizada contra a globalização; movimentos das cooperativas populares; mobilizações do movimento nacional de atingidos pelas barragens e movimentos sociais no setor de comunicações.
} 
Nesse caso, os Conselhos Municipais e Locais estudados são Conselhos de Políticas por se tratarem de conselhos vinculados a políticas públicas, estruturadas e concretizadas em sistemas nacionais, no caso da saúde e, pelo menos de forma propositiva, no caso da segurança alimentar e nutricional. No caso do meio ambiente e desenvolvimento sustentável, as características da temática também permitem defini-lo como conselho de política, apesar da inexistência de um sistema nacional estruturado.

GOHN (2005) também propõe que o universo temático das Organizações Não-Governamentais (ONG's) atua em diferentes campos $^{5}$, inclusive nas áreas sociais básicas onde estão saúde, educação, moradia e alimentação. Muitas associações voluntárias surgiram com preocupações humanitárias e acabaram por se tornar defensoras importantes dos direitos das minorias e grupos sociais excluídos. Sem dúvida, atualmente, há interesse em identificar e entender de que forma esse tipo de organização, cada vez mais presente na sociedade, estabelece relações com as instâncias e fóruns participativos e como influencia a atuação dos grupos sociais.

FUKS, PERISSINOTTO e RIBEIRO (2003) advogam que uma importante inovação dentro da teoria da cultura política é o entendimento de que "as experiências vivenciadas pelos indivíduos em instituições não-governamentais são fundamentais para a definição de suas atitudes em relação ao sistema político" (p. 138), ou seja, há que se valorizar o papel das instituições no processo de construção dos valores e crenças dos cidadãos quanto ao mundo

\footnotetext{
${ }^{5}$ Direitos de Cidadania (gênero, meio ambiente, direitos humanos, etnias, sexo); Áreas Sociais Básicas (saúde, educação, moradia, alimentação); Grupos Sociais Clássicos no atendimento da assistência social; Área da Cultura e Grupos Vulneráveis e Causas Sociais.
} 
político e também é necessário valorizar as experiências ocorridas fora do sistema político. Dessa forma, fica claro que qualquer tipo de associativismo presente e vivenciado na sociedade civil, para além das formas mais tradicionais, como sindicatos e associações profissionais (DOMBROWSKI, 2008), tem impacto sobre as formas de participação social institucionalizada e justifica-se desenvolver estudos com essa perspectiva.

Inicialmente, para o estudo dos movimentos, organizações e entidades presentes e envolvidas nos conselhos, é preciso a sua identificação, com o intuito de caracterizar seus objetivos, suas áreas de atuação e seus participantes. O mapeamento das mesmas permite conhecer as relações que estabelecem ou não entre si e isso é fundamental na medida em que as redes associativistas existentes vêm contribuindo para o empowerment dos setores populares da sociedade, ou seja, para o fortalecimento do protagonismo da sociedade civil. É a atuação dos grupos, movimentos e outros coletivos organizados como sujeitos coletivos na esfera pública, o que fortalece a sociedade civil e a sociedade política (GOHN, 2003b).

Considerando-se os processos administrativos e políticos de descentralização e atuação intersetorial, novos dilemas têm sido colocados no âmbito da participação social, para além dos conselhos setoriais já mais consolidados na sua formalização. Há possibilidade de avanços, a partir do desenvolvimento de novos e mais complexos espaços de gestão, organizados ao redor dos grandes eixos temáticos da cidade: saúde e saneamento, educação e cultura, trabalho e geração de renda. Isso tem acionado múltiplas redes sócio-políticas que alteram as relações entre Estado e sociedade civil (GOHN, 2003b). 
De acordo com JUNQUEIRA (2000) essas múltiplas redes sócio-políticas são conjuntos de pessoas e organizações que se relacionam para responder demandas e necessidades da população de maneira mais integrada e, assim, possibilitar mais eficácia na gestão das políticas sociais. Os vários conselhos setoriais das áreas sociais, conselhos regionais, comitês locais e outras iniciativas, podem se constituir em rede e atuar como instâncias de articulação para solucionar problemas que dependem, geralmente, de ações integradas entre várias áreas da administração e da sociedade.

Também podem servir como catalisadores para a disseminação de organizações civis, as mais diversas, que se vão constituindo e fortalecendo como sujeitos sociais e políticos, a partir das relações que estabelecem entre si e com as instâncias de participação formal (JUNQUEIRA, 2002; MOURA e SILVA, 2008).

Apesar dos índices de adesão aos valores democráticos serem baixos na sociedade brasileira como um todo, assim como é pequena a confiança na adoção, por parte dos governos e instituições, de princípios éticos (FERREIRA, 1999; LABRA, 2005), a abertura de canais de participação, do tipo dos conselhos, vem proporcionando a aproximação à atividade política de setores, normalmente, menos politizados. Vem re-politizando este espaço da sociedade e indicando a possibilidade de superação da atividade política como uma atividade dissociada da vida cotidiana dos indivíduos 'comuns' (GOHN, 2002; COELHO, 2004).

Dessa forma, não há dúvida de que a criação e ampliação das esferas de participação por meio dos conselhos institucionalizados para a formulação de políticas públicas, é um fenômeno importante, mas não tem sido suficiente para garantir uma participação efetiva em todas as situações. Um dos aspectos 
problemáticos destacado por vários autores (TATAGIBA, 2004; BÓGUS, 2005) refere-se à publicização das ações e decisões dos conselhos que é algo que aparece pouco nos instrumentos jurídicos que regulamentam o funcionamento dessas instâncias legais. Outros problemas identificados são: resistência das autoridades em respeitar e assumir as resoluções dos conselhos, no sentido de fazer com que sejam cumpridas; dificuldade dos conselheiros em lidarem com a pluralidade e a heterogeneidade e com a grande exigência em termos de aprendizado e tempo de dedicação que a participação requer; fragilidade e, em alguns casos, pouca transparência das organizações e associações da sociedade civil que compõem os conselhos e representatividade parcial da diversidade de grupos existentes na sociedade (LABRA, 2009).

Ao se reconhecer os conselhos como canais de participação importantes e que instâncias e fóruns deste tipo são representativos da presença e atuação dos movimentos sociais e de outras organizações na sociedade civil, mesmo com todas as limitações constatadas, autores têm indicado o estudo dos conselhos como possibilidade para 0 conhecimento mais aprofundado do tema do associativismo civil, incluindo a questão dos vínculos com os seus representados e com as entidades e/ou associações que os referendam nesses fóruns. A partir do pressuposto de que a participação em fóruns desse tipo pode fomentar um círculo virtuoso, desde o envolvimento dos cidadãos até o fortalecimento da democracia, os conselhos seguem sendo elementos a serem investigados enquanto espaços sócio-políticoculturais (LABRA, 2002; LABRA e FIGUEREDO, 2002). 

2. OBJETIVOS

O homem é menor Do que sua busca.

Lavramos o solo, Larvamos.

Nosso lar é uma enxada Nos braços.

Biografia de uma árvore - Fabrício Carpinejar 



\section{OBJETIVOS}

Esta pesquisa foi desenvolvida, no período compreendido entre fevereiro de 2006 e março de 2008, junto a instâncias participativas, características de diferentes níveis da gestão de políticas públicas municipais de São Paulo: Conselhos Municipais do Meio Ambiente e Desenvolvimento Sustentável, de Saúde e de Segurança Alimentar e Nutricional; e, no nível local, junto aos Conselhos Gestores das Supervisões Técnicas de Saúde de São Miguel Paulista, Ermelino Matarazzo e Vila Mariana, com o objetivo de:

- identificar o perfil sócio-demográfico dos seus membros;

- identificar as associações e/ou entidades a que pertencem os membros;

- caracterizar e analisar o perfil das associações e/ou entidades a que pertencem os membros dos referidos Conselhos e as relações existentes entre elas;

- identificar a percepção dos membros quanto às possibilidades de articulação e integração dos conselhos na formulação de políticas públicas intersetoriais. 

3. MÉTODOS

Um objeto sim

Um objeto não

Um surgindo do céu Outro vindo do chão.

Objeto sim, objeto não - Gilberto Gil 



\section{MÉTODOS}

\subsection{UNIVERSO DO ESTUDO}

Os Conselhos Municipais de políticas públicas do Meio Ambiente e Desenvolvimento Sustentável, de Saúde e de Segurança Alimentar e Nutricional foram escolhidos porque suas temáticas convergem de forma a se complementarem quanto às áreas sociais que contemplam no contexto urbano. Os Conselhos Gestores Locais de Saúde foram escolhidos porque é no setor saúde que existem, há mais tempo, fóruns participativos organizados de forma estruturada e regulamentada, desde o nível nacional até o local, passando pelos níveis estadual, municipal e regional.

Para selecionar os três Conselhos Gestores das Supervisões Técnicas de Saúde, as Subprefeituras foram separadas em tercis, ou seja, em três sub-conjuntos com igual número de elementos (BUSSAB e MORETTIN, 2002).

Para definir os tercis foram utilizados os valores do Índice de Exclusão Social (IEX) que variam de $-1,000$ (para o pior índice) a 1,000 (para o melhor índice). Os valores desse índice foram obtidos na página eletrônica da Prefeitura de São Paulo, em junho de 2007. Foi identificado o IEX de cada um dos noventa e cinco Distritos que compõem as 31 Subprefeituras do município de São Paulo. Os valores foram colocados em um gráfico de dispersão (ANEXO 1) e depois separados em tercis. O intervalo do primeiro tercil está compreendido entre $-1,000$ e -0,468, o intervalo do segundo tercil entre $-0,467$ e $-0,089$ e o intervalo do terceiro tercil 
entre $-0,088$ a 1,000. O primeiro e o segundo tercis abarcaram 32 Distritos cada um, e o terceiro, 31 distritos. Em seguida, analisaram-se quais as Subprefeituras que apresentavam todos os seus Distritos dentro de um mesmo tercil; este foi o primeiro critério para a escolha das três Subprefeituras. Segundo esse critério, foram encontradas 17 subprefeituras: nove no primeiro tercil (Parque Anhanguera, Cidade Ademar, Campo Limpo, M'boi Mirim, Parelheiros, São Miguel Paulista, Itaim Paulista, Guaianases e Cidade Tiradentes), quatro no segundo (Tremembé/Jaçanã, Aricanduva, Penha e Ermelino Matarazzo) e quatro no terceiro tercil (Santana, Pinheiros, Vila Mariana e Santo Amaro).

O segundo critério correspondeu a uma combinação entre a receptividade positiva para o desenvolvimento do estudo, por meio de contatos prévios com a Coordenadoria de Saúde e Supervisão Técnica de Saúde, a possibilidade de acesso geográfico e de transporte à região e a dispersão, dentro de cada tercil, dos Distritos que compõem cada uma das Subprefeituras.

Desta forma, do primeiro tercil foram excluídas as Subprefeituras de Parque Anhanguera, Cidade Ademar, Campo Limpo e M'Boi Mirim. A Subprefeitura de Parelheiros foi descartada pela localização geográfica. Restaram São Miguel Paulista, Itaim Paulista, Guaianases e Cidade Tiradentes. Quando as Coordenadorias de Saúde, responsáveis por essas Subprefeituras foram contatadas, constatou-se que em Guaianases e Cidade Tiradentes o setor saúde encontrava-se em transição de administração, saindo do controle direto da administração municipal para o controle das organizações sociais de saúde. Isso fez com que essas Subprefeituras fossem descartadas, por se tratar de situação não típica naquele momento. Por fim, o critério 
de desempate entre São Miguel Paulista e Itaim Paulista foi a dispersão dos Distritos no tercil: Itaim Paulista apresentava dois Distritos muito próximos, segundo os valores do IEX, enquanto São Miguel Paulista apresentava três Distritos localizados em diferentes pontos do mesmo tercil. Avaliou-se, então, que seria mais interessante trabalhar com a Subprefeitura de São Miguel Paulista.

No segundo tercil foi observado que a Subprefeitura de Aricanduva encontrava-se muito próxima do terceiro tercil e a Subprefeitura de Tremembé/Jaçanã muito próxima do primeiro. Considerando isso e a facilidade de contato com o setor saúde, foi escolhida a Subprefeitura de Ermelino Matarazzo.

Processo semelhante deu-se com a escolha da Subprefeitura do terceiro tercil a compor a pesquisa: Santana e Santo Amaro encontravam-se muito próximas do segundo tercil e, pelo contato com a Supervisão Técnica de Saúde, entre as duas restantes, selecionou-se a Subprefeitura de Vila Mariana.

Por fim, as Subprefeituras selecionadas foram: São Miguel Paulista, do primeiro tercil; Ermelino Matarazzo, do segundo tercil; e Vila Mariana, do terceiro tercil.

Cabe esclarecer alguns processos ocorridos nos últimos anos, no âmbito da Prefeitura do Município de São Paulo, relativos à estrutura e organização do setor saúde. Antes da divisão em Supervisões Técnicas de Saúde havia a Coordenadoria de Saúde da Subprefeitura de Ermelino Matarazzo e a Coordenadoria de Saúde da Subprefeitura de São Miguel Paulista. Com a organização do setor saúde em cinco Coordenadorias Regionais de Saúde, as Subprefeituras de Ermelino Matarazzo e São Miguel Paulista passaram a compor, oficialmente, apenas uma Supervisão Técnica de Saúde. Porém, segundo esclarecimento dado pela Supervisora 
Técnica de Saúde de Ermelino Matarazzo, as Coordenadorias de Saúde de ambos os Distritos eram completamente independentes uma da outra, com corpos administrativos diferentes e funcionando em prédios diferentes que não eram nem próximos fisicamente. Diante disso, as duas coordenadorias optaram por manter duas Supervisões Técnicas de Saúde independentes, mas com o mesmo nome, ou seja, na listagem oficial das Supervisões Técnicas de Saúde aparecia duas vezes a Supervisão Técnica de Saúde de Ermelino Matarazzo/São Miguel Paulista, mas com endereços e Supervisores Técnicos diferentes. Em relação aos conselhos gestores, mantiveram-se os dois conselhos, funcionando de maneira independente.

Com as Coordenadorias de Saúde de Vila Mariana e Jabaquara deu-se processo semelhante. Com a criação das Supervisões Técnicas de Saúde essas duas Coordenadorias tornaram-se apenas uma, porém, ao contrário do que aconteceu em Ermelino Matarazzo e São Miguel Paulista, o corpo administrativo e o local de funcionamento também passaram a ser o mesmo. Por outro lado, havia dois conselhos gestores diferentes em funcionamento que, apesar da junção das antigas Coordenadorias de Saúde, continuaram funcionando independentemente, porém, apoiados pela mesma Supervisão Técnica de Saúde.

\subsection{COLETA DE DADOS}

Esse trabalho constitui-se em um estudo de caso e seu alcance de generalização é limitado, mas indica aspectos interessantes para a compreensão dos processos de 
descentralização e democratização na gestão pública, em especial no que se refere à formulação e implementação de políticas públicas integradas e intersetoriais em metrópoles brasileiras.

Foram combinadas técnicas para a coleta de dados quantitativos e qualitativos, para realizar uma análise qualitativa (HAGUETTE, 1990; MINAYO, 1993), que permitisse a compreensão do objeto do estudo, de forma contextualizada.

A coleta de dados foi feita, nos anos de 2006 e 2007, com a utilização de diferentes técnicas que, em alguns momentos, ocorreram simultaneamente. Foram utilizadas, basicamente, a análise documental, a entrevista individual e a observação de reuniões. O uso conjunto de várias técnicas teve o intuito de permitir a complementação das informações e a melhor compreensão possível dos objetos que se pretendia estudar.

A análise documental é indicada quando se pretende ratificar e validar informações (LUDKE e ANDRÉ, 1986) e permitiu analisar os documentos produzidos em cada uma das instâncias estudadas sobre a atuação dos referidos conselhos.

A entrevista permite tanto a obtenção de informações denominadas mais objetivas como outras de caráter mais subjetivo, referente às atitudes, percepções e valores dos indivíduos entrevistados.

Para a realização das entrevistas com os conselheiros foi elaborado um roteiro estruturado, contendo perguntas fechadas e abertas, seguindo um esquema básico (LUDKE e ANDRÉ, 1986; BRIOSCHI e TRIGO, 1987; CRUZ NETO, 2001). Era composto de quatros partes: (A) Identificação do entrevistado, (B) Identificação da associação e/ou entidade que representa, (C) Percepção sobre as instâncias de participação e (D) Percepção sobre as 
possibilidades de intervenção nas políticas públicas (ANEXO 2).

A seleção dos entrevistados levou em conta a composição dos Conselhos, no sentido de garantir a representação de todos os segmentos que compunham cada Conselho.

Os dados coletados por meio das entrevistas permitiram traçar um perfil sócio-demográfico (sexo, faixa etária, situação de emprego, grau de escolaridade) dos membros dos Conselhos selecionados e também permitiu identificar e traçar um panorama das associações e/ou entidades representadas pelos conselheiros (tipo de associação, área de atuação, atividades desenvolvidas) e as relações existentes entre elas.

A técnica da observação direta (LUDKE e ANDRÉ, 1986) de algumas reuniões dos Conselhos possibilitou um contato mais estreito com o fenômeno pesquisado, permitindo maior proximidade com a perspectiva dos conselheiros (ANEXO 3).

No Conselho Municipal do Meio Ambiente e Desenvolvimento Sustentável (CADES) foram entrevistados dezoito (28,12\%) conselheiros, do total de 64 membros (ANEXO 4): onze do segmento da administração (dez titulares e um suplente) e sete do segmento da sociedade civil (cinco titulares e dois suplentes).

No Conselho Municipal de Saúde (CMS), foram entrevistados dezoito conselheiros $(28,1 \%)$ do total de 64 membros (ANEXO 5), sendo cinco do segmento da administração (cinco titulares), quatro do segmento dos trabalhadores (quatro titulares) e nove do segmento da sociedade civil (nove titulares).

No Conselho Municipal de Segurança Alimentar e Nutricional (COMUSAN), foram entrevistados 22 conselheiros $(27,5 \%)$ do total de 80 membros (ANEXO 6): cinco do segmento da administração 
(três titulares e dois suplentes), seis do segmento dos trabalhadores (cinco titulares e um suplente) e onze do segmento da sociedade civil (onze titulares).

A composição do Conselho Gestor da Supervisão Técnica de Saúde de São Miguel Paulista era de 32 membros, sendo dezesseis conselheiros titulares e dezesseis suplentes, segundo a distribuição regimental para os segmentos: $50 \%$ para o segmento dos usuários - dezesseis membros no total, sendo oito titulares e oito suplentes; $25 \%$ para o segmento da administração - oito membros no total, sendo quatro titulares e quatro suplentes (uma das vagas de titular e uma das de suplente destinadas aos representantes dos prestadores de serviços); e $25 \%$ para o segmento dos trabalhadores da área - oito vagas no total que, no período da pesquisa, ainda não haviam sido ocupadas. Assim, do total de 24 membros existentes, sete foram entrevistados $(29,2 \%)$, sendo: quatro do segmento dos usuários (todos titulares) e três do segmento da administração (todos titulares).

O número de membros do Conselho Gestor da Supervisão Técnica de Saúde de Ermelino Matarazzo era de 24 conselheiros titulares e vinte conselheiros suplentes porque no segmento dos usuários não foram completadas todas as vagas de membros suplentes. Então, havia vinte conselheiros do segmento dos usuários (doze titulares e oito suplentes), doze conselheiros do segmento dos trabalhadores da área (seis titulares e seis suplentes) e doze conselheiros do segmento da administração (seis titulares e seis suplentes). Do total de 44 membros do Conselho, quinze foram entrevistados (34\%), sendo sete do segmento dos usuários (seis titulares e um suplente); quatro do segmento dos trabalhadores da área (todos titulares) e quatro do segmento da 
administração (todos titulares).

A composição vigente, à época da investigação, do Conselho Gestor da Supervisão Técnica de Saúde de Vila Mariana era de dezoito conselheiros, sendo dezessete titulares e um suplente, distribuídos da seguinte forma: nove representantes do segmento dos usuários, seis representantes do segmento dos trabalhadores e três representantes do segmento da administração. Não havia suplentes devido à falta de número de candidatos suficiente na eleição. Do total de dezoito membros foram entrevistados dez $(55,5 \%)$, distribuídos conforme segue: quatro do segmento dos usuários (todos titulares); quatro do segmento dos trabalhadores da área (todos titulares) e dois do segmento da administração (todos titulares).

Figura 1 - Cobertura de entrevistas realizadas junto ao Conselho Municipal do Meio Ambiente e Desenvolvimento Sustentável (CADES), Conselho Municipal de Saúde (CMS) e Conselho Municipal de Segurança Alimentar e Nutricional (COMUSAN) e Conselhos das Supervisões Técnicas de Saúde de São Miguel Paulista, Ermelino Matarazzo e Vila Mariana, por segmento, São Paulo, 2006 e 2007.

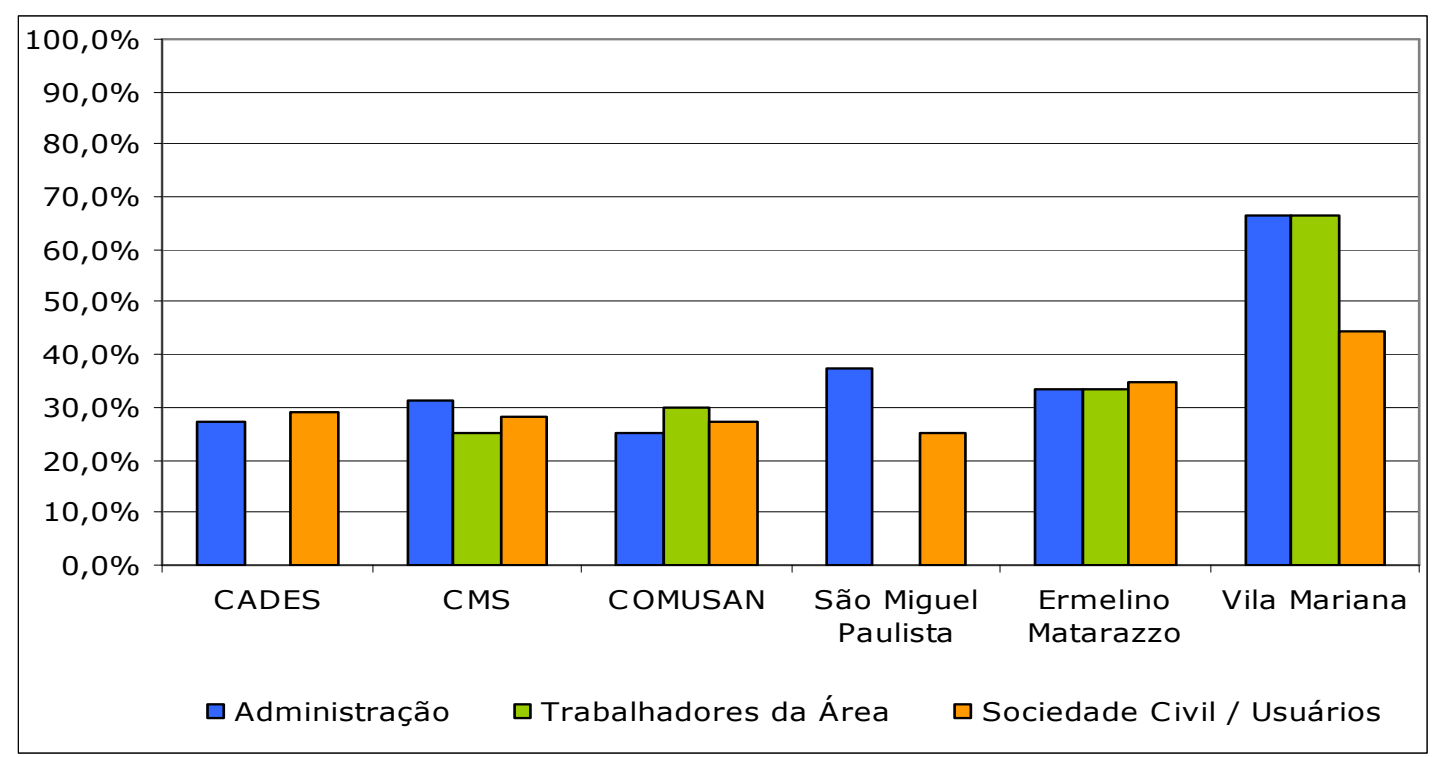


Com o intuito de se obter dados sobre o histórico e organização dos Conselhos das Supervisões de Saúde também foram realizadas entrevistas com os responsáveis técnicos pelos Conselhos Gestores das Supervisões Técnicas de Saúde de São Miguel Paulista, Ermelino Matarazzo e Vila Mariana, conforme roteiro em anexo (ANEXO 7).

Em São Miguel Paulista foram entrevistadas a supervisora técnica de saúde, que é a responsável técnica pelo conselho, e a secretária da Supervisão Técnica de Saúde que auxilia na organização e operacionalização do conselho, além de substituir a supervisora quando necessário.

Em Ermelino Matarazzo a entrevista foi realizada com a própria supervisora técnica de saúde, que é a profissional que acompanha o conselho gestor.

Na Vila Mariana foi entrevistada a supervisora técnica de saúde e outra profissional que é a responsável técnica pelo conselho.

Para aprofundar o conhecimento quanto à organização e funcionamento desses conselhos locais também foram estudados seus Regimentos Internos.

\subsection{ANÁLISE DOS DADOS}

Os dados coletados por meio das entrevistas individuais com os conselheiros foram digitados e compilados com o uso dos programas Epi Info (EPI INFO, version 3.3.2; 2005) e Statistical Package for the Social Science (SPSS, version 13; 2004). Foram confeccionadas seis bases de dados, uma para cada Conselho 
estudado.

Em uma primeira etapa foram compiladas as perguntas fechadas e, posteriormente, as variáveis relacionadas com as perguntas abertas foram categorizadas para permitir a descrição e a análise de cada um dos Conselhos.

O processo de categorização consistiu na leitura exaustiva de todas as respostas obtidas para cada questão, agrupamento de respostas similares e com mesmo significado e definição de categorias relevantes para o estudo.

Esse procedimento foi feito tanto para os Conselhos Municipais quanto para os Conselhos Gestores. Na fase relativa aos Conselhos Gestores consideraram-se, na medida do possível, as categorias já existentes em função da categorização já elaborada. As respostas foram lidas e para cada uma foi indicada uma categoria das existentes, salvas as adequações necessárias, não pela mudança do conteúdo da categoria, mas por alteração de texto, uma vez que as categorias existentes anteriormente diziam respeito a instâncias municipais $e$ as respostas a serem categorizadas referiam-se a instâncias locais. E quando se fez necessária mudança de conteúdo ou a resposta não apresentava uma categoria correspondente, foram adicionadas novas categorias, sem mudança de numeração das já existentes.

O uso da categorização elaborada na fase da pesquisa com os Conselhos Municipais permitiu o estudo comparativo dos resultados dos diferentes Conselhos, possibilitando 0 estabelecimento de relações entre as instâncias de participação e as características dos conselheiros e das associações e entidades identificadas.

As observações das reuniões dos Conselhos e a realização 
das entrevistas com roteiros específicos com os responsáveis técnicos dos Conselhos Gestores foram complementadas com 0 estudo dos Regimentos Internos e da legislação específica, a fim de permitir a compreensão de sua organização e funcionamento, pois é possível considerar que estes aspectos influenciam a dinâmica de participação das pessoas nos conselhos e, ao mesmo tempo, a composição do conselho também determina a forma como ele se organiza.

Todos esses procedimentos permitiram uma análise descritiva dos dados coletados, considerando os objetivos pretendidos.

Buscou-se também verificar a existência de grupos característicos entre os conselheiros estudados, por meio da análise de agrupamento (Cluster), na qual as distâncias entre as medidas realizadas (variáveis) são calculadas dentro do espaço multiplano e, então, os objetos são agrupados de acordo com a proximidade entre eles (PEREIRA, 1999). Para esse procedimento não foram utilizadas todas as variáveis, mas apenas algumas consideradas as possivelmente mais discriminatórias, a partir da análise descritiva anterior.

\subsection{ASPECTOS ÉTICOS}

O projeto foi aprovado pelo Comitê de Ética em Pesquisa da Faculdade de Saúde Pública da USP (Of. COEP/225/05) e pelo Comitê de Ética em Pesquisa da Secretaria Municipal de Saúde de São Paulo (Parecer $n^{\circ}$ 130/2005 - CEPSMS), de acordo com a Resolução $n^{0} 196$ de outubro de 1996 do Conselho Nacional de 
Saúde (ANEXOS 8 e 9).

Todos os informantes foram esclarecidos quanto aos aspectos éticos, concordaram com os procedimentos propostos e assinaram o Termo de Consentimento Livre e Esclarecido, cujo modelo encontra-se em anexo (ANEXO 10). 


\section{RESULTADOS E DISCUSSÃO}

Da janela, o mundo até parece o meu quintal Viajar, no fundo, é ver que é igual O drama que mora em cada um de nós Descobrir no longe o que já estava em nossas mãos

Minha vida brasileira é vida universal É o mesmo sonho, é o mesmo amor Traduzido para tudo o que humano for

Olhar o mundo é conhecer Tudo o que eu já teria que saber.

Janela para o mundo - Milton Nascimento e Fernando Brant 



\section{RESULTADOS E DISCUSSÃO}

\subsection{OS CONSELHOS MUNICIPAIS - MEIO AMBIENTE E DESENVOLVIMENTO SUSTENTÁVEL, SAÚDE E SEGURANÇA ALIMENTAR E NUTRICIONAL}

\section{Composição, organização e infra-estrutura}

Todos os representantes da administração municipal do CADES (60\% dos seus membros) são indicados pelo prefeito. Com relação aos representantes da sociedade civil (40\% dos membros) cabe ao prefeito, a partir de lista encaminhada pelo segmento, fazer a escolha sobre quais entidades ocuparão as vagas e, então, cada entidade indica quem a representará.

O Conselho Municipal de Saúde tem uma ampla representação dos usuários da rede pública de saúde, o que o difere um pouco do CADES e do COMUSAN que têm maior presença de profissionais ou entidades que atuam na área, mesmo entre os representantes do segmento da sociedade civil. Isso pode ser conseqüência da origem do CMS, que é um dos mais antigos e está relacionada com os movimentos sociais de saúde bastante atuantes nas décadas de 1970 e 1980.

A composição do COMUSAN é semelhante ao do CMS em termos de proporção de membros por segmento. Vale destacar que ele foi criado tendo o Regimento do CMS como sua referência.

Com relação à forma de funcionamento dos Conselhos, temse como depoimento recorrente dos entrevistados, de todos os Conselhos Municipais, que as decisões são tomadas por meio de votação, precedida de plenárias de discussão. 
Isso pode indicar que há uma preocupação com o cumprimento de determinados procedimentos, tidos como passos necessários para garantir a lisura de processos democráticos. Nessa linha, os procesos de eleição e de votação são considerados como pontos centrais da democracia, pois representam a oportunidade de manifestação igualitária de todos: cada cabeça corresponde a um voto, com o mesmo peso. O que cabe aqui ponderar é o que tem sido destacado por autores em estudos sobre a dinâmica de conselhos gestores: apesar de cada voto valer o mesmo, os procedimentos estão imersos nas relações de poder presentes; o que significa dizer que grupos com diferentes níveis sócio-econômicos não dispõem das mesmas condições para a manifestação de suas posições e isso, certamente, influenciará no resultado das votações relativas às decisões dos conselhos (WENDHAUSEN e CAPONI, 2002; WENDHAUSEN e CARDOSO, 2007).

Neste estudo verificou-se que os três conselhos municipais realizam reuniões mensais, diferentemente do que acontece com $38 \%$ dos conselhos municipais investigados por DOMBROWSKI (2008) em municípios do interior do Estado do Paraná, onde as reuniões são bimestrais, trimestrais, semestrais ou não têm periodicidade definida. Assim, é preciso reconhecer que 0 cumprimento da regularidade mensal das reuniões é um aspecto que deve ser valorizado, pois é um elemento facilitador para o aprendizado e desenvolvimento de habilidades importantes para a prática participativa e deliberativa, desde o conhecimento dos procedimentos regimentais, maior familiaridade com as temáticas até o reconhecimento dos diferentes interesses dos grupos envolvidos. Esse é um tipo de aprendizado que se dá na prática e não pode ser substituído por capacitações formais. 
Figura 2 - Distribuição dos temas presentes nas reuniões do Conselho Municipal do Meio Ambiente e Desenvolvimento Sustentável (CADES), Conselho Municipal de Saúde (CMS) e Conselho Municipal de Segurança Alimentar e Nutricional (COMUSAN), São Paulo, 2006 e 2007.

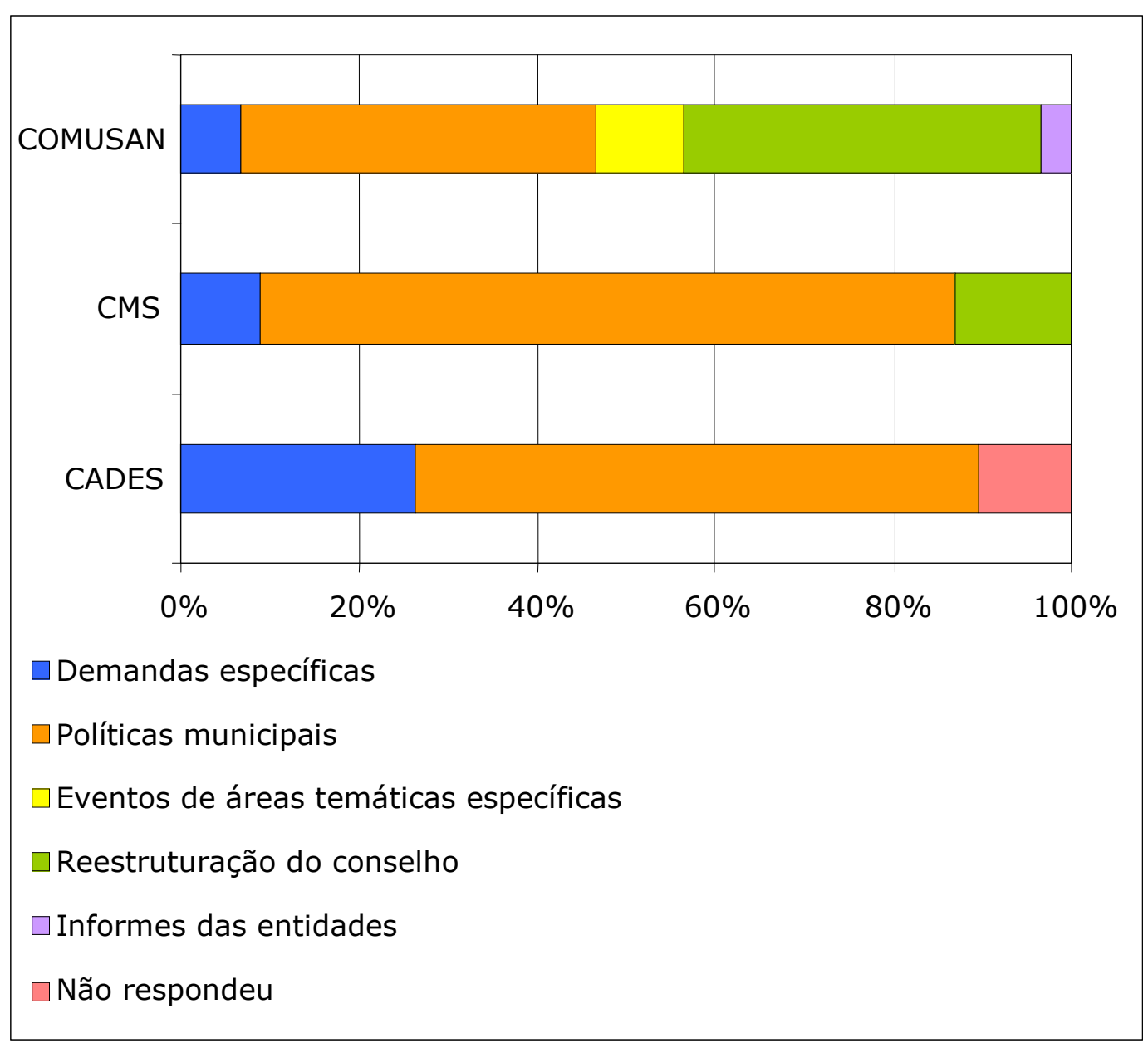

Conforme esperado, os temas mais presentes nas pautas dos Conselhos são as políticas municipais e, em seguida, há referência à discussões relacionadas com a reestruturação do próprio Conselho no CMS e no COMUSAN, indicando que nesses Conselhos pode haver algum tipo de insatisfação quanto à forma de funcionamento dos mesmos.

Na pesquisa Monitoramento e Apoio à Gestão Participativa do 
SUS $^{6}$ (ESCOREL e DELGADO, 2008) encontrou-se que os temas discutidos mais regularmente nas reuniões dos Conselhos Estaduais de Saúde foram: (1) políticas, planejamento e gestão em saúde, (2) atenção à saúde, (3) controle social e estrutura, organização, funcionamento e atuação do conselho, (4) recursos humanos e gestão do trabalho. Apesar de serem instâncias estaduais é possível fazer uma comparação, considerando tratar-se de São Paulo, maior município do país. Assim, verificam-se convergências nos principais temas, que se referem às definições de políticas e programas e ao funcionamento das estruturas criadas para o controle social. O mesmo também foi encontrado na pesquisa desenvolvida junto aos Conselhos Municipais de Saúde de Angra dos Reis, Duque de Caxias, Niterói, Resende e Volta Redonda (GERSCHMAN, 2004).

Com relação ao funcionamento e organização de conselhos gestores de políticas públicas - das áreas de saúde, assistência social e direitos da criança e do adolescente -, TATAGIBA (2002) também encontrou que grande parte da atuação dos mesmos tem a ver com sua própria estruturação e organização interna.

Tudo isso indica que há insatisfação, demonstrada pelos conselheiros, que percebem problemas que limitam 0 funcionamento a contento dos conselhos e procuram obter espaço para tais discussões e busca de soluções. Esses são indícios de não acomodação pela conquista das instâncias formais institucionais,

\footnotetext{
${ }^{6}$ A pesquisa Monitoramento e Apoio à Gestão Participativa do SUS vem sendo desenvolvida desde 2003 pelos Departamentos de Ciências Sociais e de Administração e Planejamento em Saúde da Escola Nacional de Saúde Pública (ENSP/FIOCRUZ) com o apoio da Secretaria de Gestão Estratégica e Participativa do Ministério da Saúde (SGEP/MS) e tem por objetivo mapear os conselhos estaduais e municipais de saúde, levantar dados e informações sobre suas características e formas de funcionamento. Um de seus produtos foi a criação do portal virtual ParticipaNetSUS (www.ensp.fiocruz.br/participanetsus).
} 
além de tentativas, em alguns casos, de aproximar as normas e as práticas, considerando que os espaços institucionais de participação têm formalidades e regras que podem acabar por descaracterizar a participação social ou dificultar a manifestação dos representantes da população em geral.

\section{Perfil sócio-demográfico dos conselheiros}

Verifica-se uma homogeneidade quanto ao perfil dos conselheiros participantes do CADES: com exceção de $15 \%$ de membros da sociedade civil que tem o $3^{\circ} \mathrm{grau}$ incompleto, todos os demais possuem $\circ 3^{\circ}$ grau completo e renda mensal individual acima de cinco salários mínimos. A faixa etária predominante é de 45 a 60 anos nos dois segmentos.

Figura 3 - Perfil sócio-demográfico dos conselheiros entrevistados do Conselho Municipal do Meio Ambiente e Desenvolvimento Sustentável (CADES), segundo segmento, São Paulo, 2006 e 2007.

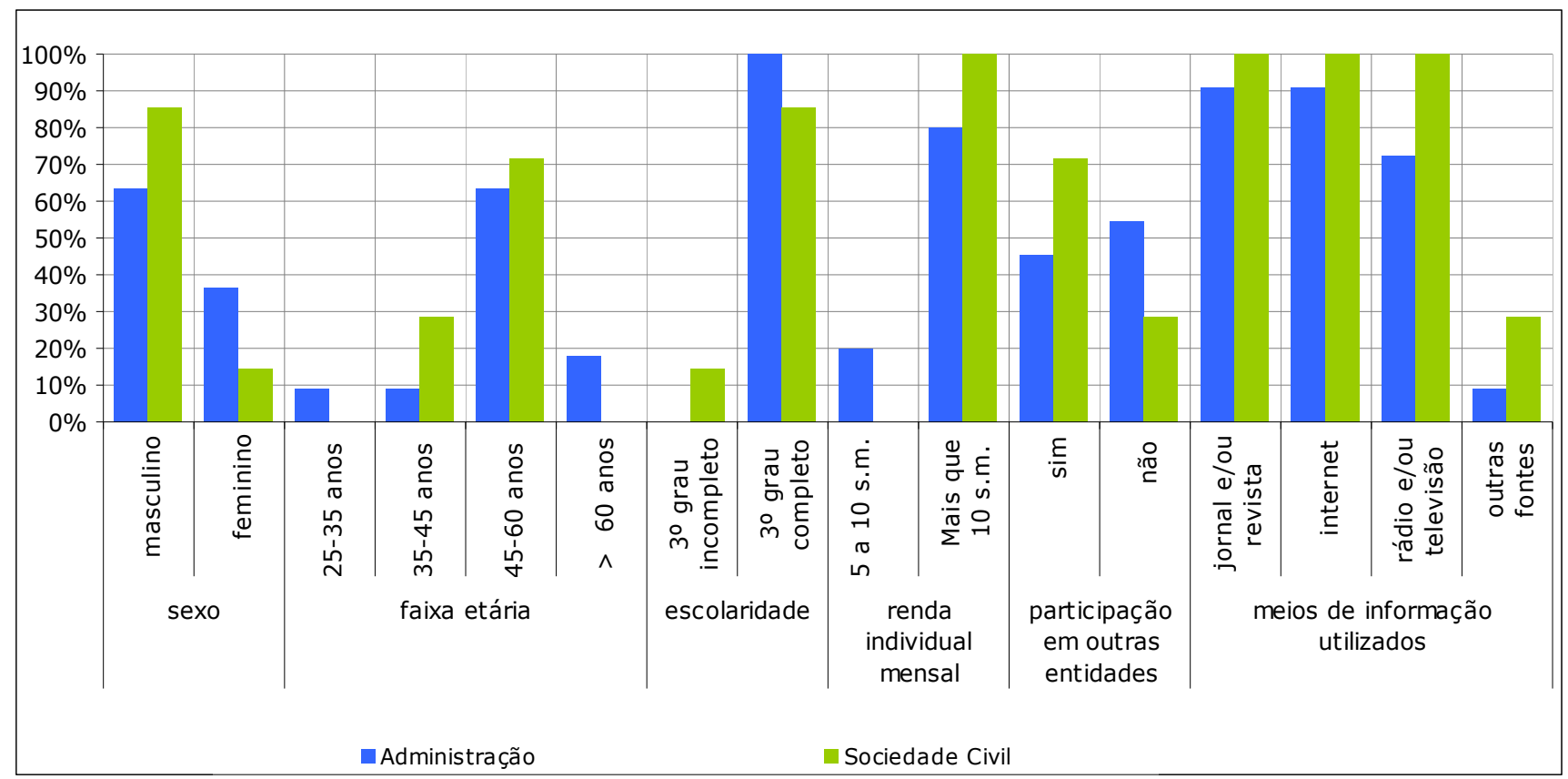


A grande maioria entrevistada (72\%) no CADES exerce atividade profissional no setor público; é preciso considerar que o maior número de representantes do segmento da administração municipal contribui para isso.

Os meios de informação mais utilizados dentre os conselheiros do CADES são jornal e/ou revista e internet (ambos com $94,4 \%$ ) e uma grande porcentagem também refere o uso do rádio e/ou televisão $(83,3 \%)$.

No Conselho Municipal de Saúde, pode-se notar uma maior diversidade quanto ao perfil dos conselheiros com relação à escolaridade e renda mensal individual: por exemplo, no segmento da sociedade civil, tanto a escolaridade $(11,1 \%$ dos membros desse segmento tem $1^{\circ}$ grau completo, $11,1 \%$ tem $2^{\circ}$ grau incompleto, $66,7 \%$ tem $2^{\circ}$ grau completo e $11,1 \%$ tem $3^{\circ}$ grau incompleto), quanto à renda (57,1\% tem renda até três salários mínimos e $42,9 \%$ tem entre três e cinco salários mínimos) são inferiores às dos demais segmentos - $100 \%$ dos membros dos segmentos da administração e dos trabalhadores tem $3^{\circ}$ grau completo e $100 \%$ dos membros do segmento da administração tem renda de mais de dez salários míninos e no segmento dos trabalhadores, $25 \%$ tem renda entre cinco e dez salários mínimos e 75\% tem mais de dez salários mínimos.

Apenas quatro dos membros entrevistados $(22,2 \%)$ do CMS exercem atividade profissional junto ao setor público, o que, de certa forma, reforça o dado de que a representação, nesse caso, é mais diversa e feita pelos que usam os serviços de saúde e não têm vínculo profissional com a área temática.

Especificamente com relação às categorias sexo $(61,1 \%$ masculino) e faixa etária ( $50 \%$ estão entre 45 e 55 anos), os dados 
encontrados neste estudo sobre o CMS, coincidem com os dados de outros trabalhos realizados no Rio de Janeiro (LABRA e FIGUEIREDO, 2002; BORGES, 2004) e em Santa Catarina (WENDHAUSEN, BARBOSA e BORBA, 2006) que estudaram o perfil dos conselheiros de saúde.

Figura 4 - Perfil sócio-demográfico dos conselheiros entrevistados do Conselho Municipal de Saúde (CMS), segundo segmento, São Paulo, 2006 e 2007.

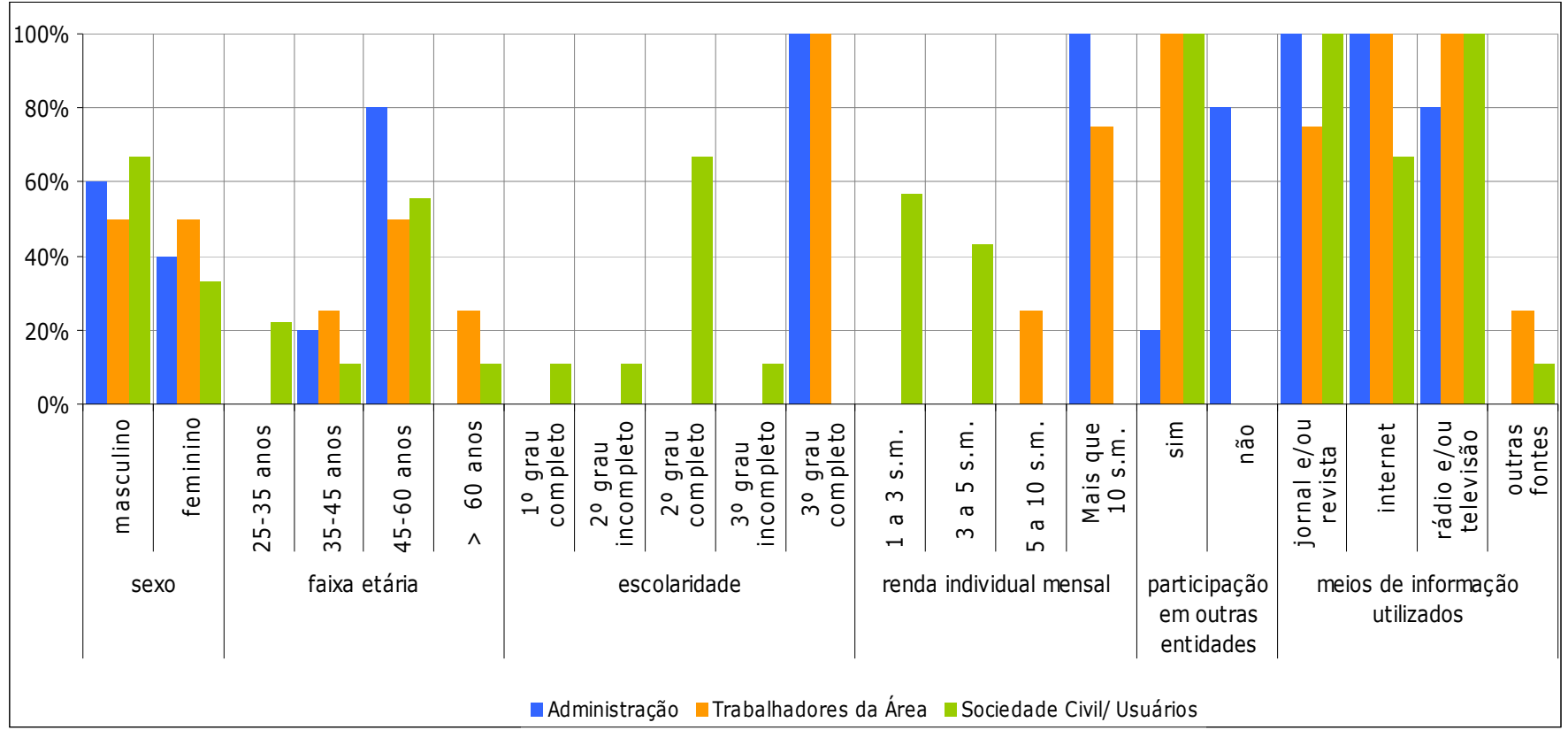

Com relação aos meios de informação utilizados, os mais citados foram jornal e/ou revista e radio e/ou televisão $(94,4 \%$ para as duas variáveis); o uso da internet ficou em segundo lugar $(83,3 \%)$.

No caso do COMUSAN, com relação à faixa etária e sexo, há correspondência com os dados encontrados na pesquisa desenvolvida junto ao COMUSAN de Itajaí (WENDHAUSEN, BARBOSA e BORBA, 2006). Em estudo realizado sobre o Conselho 
Nacional de Segurança Alimentar e Nutricional (CONSEA), pôde-se observar que $97 \%$ dos conselheiros da sociedade civil tinham ensino de $3^{\circ}$ grau ou pós-graduação (COSTA, 2008), o que é similar ao encontrado em São Paulo pois, apesar do segmento da sociedade civil ter o nível de escolaridade e de renda abaixo dos demais segmentos, a porcentagem que tem ensino superior completo é alta $(90,9 \%)$. O que é diferente, na comparação com o CONSEA, é a porcentagem de homens e mulheres: no CONSEA, $60 \%$ dos representantes da sociedade civil são homens e no COMUSAN de São Paulo, menos de $40 \%$. Aqui, vale mencionar que, tradicionalmente, com algumas mudanças recentes, nos espaços políticos com mais destaque, há predominância da presença masculina.

No COMUSAN destaca-se a presença de profissionais da área como membros, tanto do segmento de trabalhadores, quanto da sociedade civil. Esse Conselho caracteriza-se pela maioria de seus membros ser mulher $(63,6 \%)$, o que corresponde às características de uma grande porcentagem de profissionais da área. Com relação à idade, $50 \%$ dos membros dos três segmentos estão na faixa etária entre 45 e 60 anos. A maior parte dos seus membros entrevistados (59\%), não atua junto ao serviço público, o que é similar ao que acontece no CMS.

Quanto aos meios de informação mais utilizados, a internet foi a mais citada $(95,5 \%)$; jornal e/ou revista $(90,9 \%)$ e radio e/ou televisão $(86,4 \%)$ também obtiveram alta porcentagem. 
Figura 5 - Perfil sócio-demográfico dos conselheiros entrevistados do Conselho Municipal de Segurança Alimentar e Nutricional (COMUSAN), segundo segmento, São Paulo, 2006 e 2007.

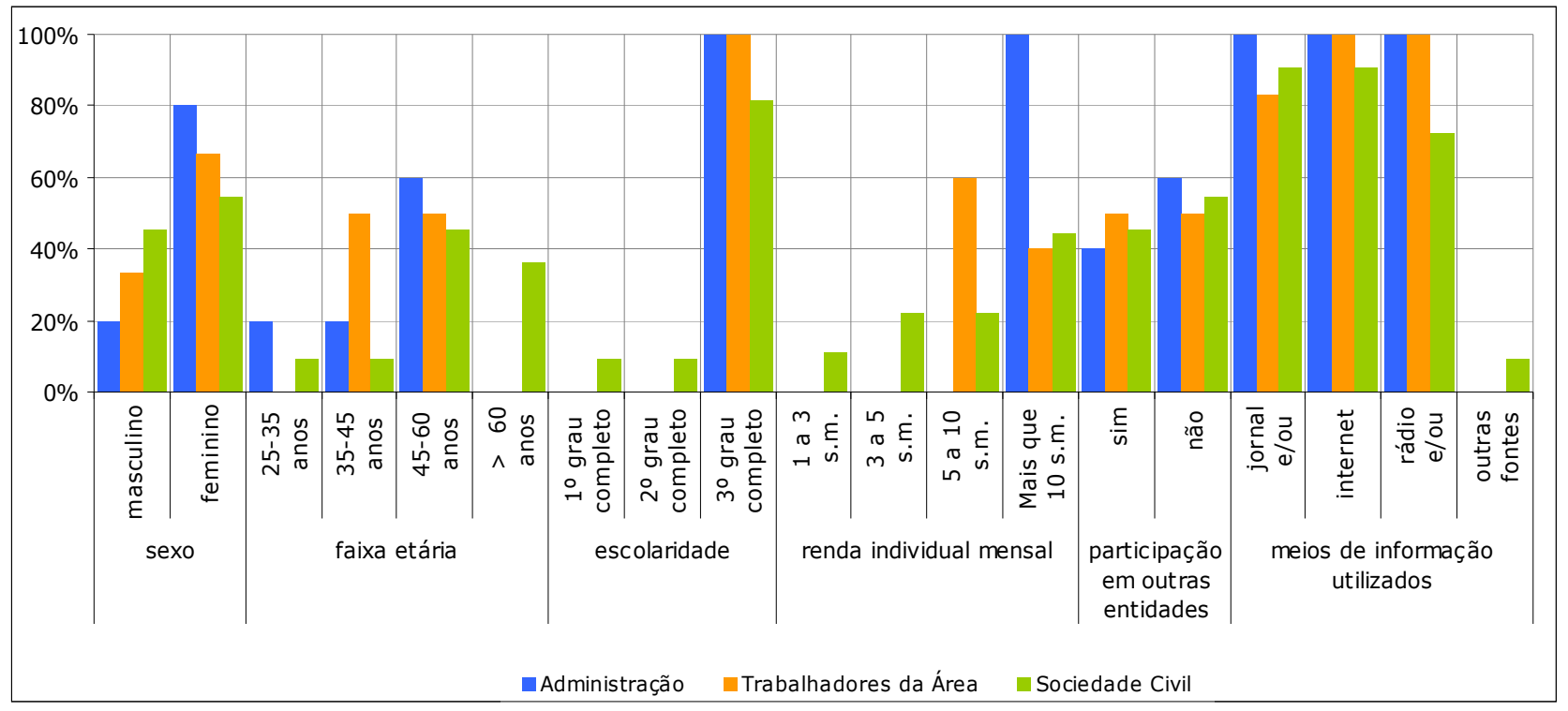

Considerando os dados do Censo de 2000 para o município de São Paulo ${ }^{7}$, constata-se que os representantes da sociedade civil presentes nos conselhos municipais não são, de forma geral, representativos das classes populares, conforme já verificado em outros estudos que levantaram o perfil sócio-demográfico de conselheiros (ABERS e KECK, 2008; FUKS, PERISSINOTTO e RIBEIRO, 2003; WENDHAUSEN, BARBOSA e BORBA, 2006): enquanto a maioria, nos conselhos municipais estudados, tem, no mínimo, onze anos de estudo (o que equivaleria ao número de anos de estudo para obtenção do $2^{\circ}$ grau completo), no município de São Paulo, apenas $17,5 \%$ tem até onze anos de estudo e $14,7 \%$ tem mais de doze anos de estudo. No caso da renda, em São Paulo, somente $25 \%$ das pessoas tem renda superior a cinco salários mínimos e todos conselheiros do CADES e do COMUSAN têm renda de mais de cinco salários mínimos. Só no caso do CMS é

7 Fonte: IBGE. Censo Demográfico 2000; Fundação Seade. 
que há maior correspondência com o encontrado no município quanto à renda: $59,1 \%$ dos habitantes de São Paulo tem renda até três salários míninos e no CMS a porcentagem é de 57,1\%. Também é nesse Conselho que estão mais presentes os representantes de entidades e organizações populares e comunitárias de caráter local.

Em todos os Conselhos foram altas as porcentagens relativas ao uso dos principais e mais comuns meios de comunicação para acesso à informação, sejam impressos, audio-visuais ou virtuais, indicando que esses conselheiros compõem um grupo que se informa. Tal informação é importante porque aponta para a possibilidade de ampliar e agilizar as formas de comunicação entre o poder público e os conselheiros e entre os próprios conselheiros, com o uso da internet.

Principalmente no CADES e no CMS, confirmou-se a idéia de que as pessoas que participam, em geral, participam de mais de uma associação, entidade ou fórum: têm uma atitude participativa e repetem um padrão de maior militância. Assim, 71,4\% dos membros da sociedade civil do CADES participam de outras organizações, além daquela que representam no Conselho, e no CMS, $100 \%$ dos trabalhadores e dos usuários pertencem a outras entidades.

Do lado da administração, os índices são bem mais baixos: $45 \%$ no CADES e $20 \%$ no CMS tem vínculo com alguma associação ou entidade. Isso pode ter reflexos no comportamento desses representantes do poder público nas instâncias participativas institucionalizadas, na medida em que têm menos oportunidades de vivenciar práticas, desenvolver e aprimorar habilidades importantes para o processo deliberativo entre grupos com 
diferentes experiências e interesses.

No COMUSAN, embora, seja menor o grau de associativismo na sociedade civil (45,5\% participa de outras entidades) e no segmento dos trabalhadores ( $50 \%$ participa de outras entidades), ainda assim ele é maior do que entre os gestores (apenas $40 \%$ participa de alguma associação).

No estudo de FUKS, PERISSINOTO e RIBEIRO (2003) feito em Curitiba foram encontrados índices bem mais altos de associativismo entre os gestores $(89,5 \%)$.

\section{As entidades representadas}

São os membros dos segmentos da sociedade civil e do segmento dos trabalhadores da área que são representantes de entidades e/ou organizações, pois os membros do segmento da administração representam o poder público municipal e são designados para compor os conselhos e não têm que ter vínculo com nenhuma entidade e/ou associação.

No Quadro 1, a seguir, estão listadas as entidades e/ou associações representadas pelos conselheiros entrevistados no CADES, CMS E COMUSAN. 
Quadro 1 - Entidades e/ou associações representadas pelos conselheiros entrevistados no Conselho Municipal do Meio Ambiente e Desenvolvimento Sustentável (CADES), Conselho Municipal de Saúde (CMS) e Conselho Municipal de Segurança Alimentar e Nutricional (COMUSAN), São Paulo, 2006 e 2007.

\begin{tabular}{|c|c|c|}
\hline CADES & CMS & COMUSAN \\
\hline $\begin{array}{l}\text { AMJS- Associação dos } \\
\text { Moradores do Jardim } \\
\text { Saúde }\end{array}$ & $\begin{array}{c}\text { Ação da Cidadania } \\
\text { São Paulo }\end{array}$ & $\begin{array}{c}\text { Ação da Cidadania } \\
\text { São Paulo }\end{array}$ \\
\hline $\begin{array}{c}\text { CREA - Conselho } \\
\text { Regional de } \\
\text { Engenharia, Arquitetura } \\
\text { e Economia }\end{array}$ & $\begin{array}{c}\text { Conselho Municipal da } \\
\text { Pessoa com } \\
\text { Deficiência }\end{array}$ & $\begin{array}{c}\text { ABPA - Associação } \\
\text { Brasileira de Prevenção } \\
\text { de Acidentes }\end{array}$ \\
\hline $\begin{array}{l}\text { FECOMERCIO - } \\
\text { Federação do Comércio } \\
\text { do Estado de São Paulo }\end{array}$ & $\begin{array}{l}\text { FACESP - Federação } \\
\text { das Associações } \\
\text { Comunitárias do } \\
\text { Estado de São Paulo }\end{array}$ & $\begin{array}{c}\text { ABVAA - Associação } \\
\text { Beneficente Vila } \\
\text { Araguaia e Adjacências }\end{array}$ \\
\hline $\begin{array}{l}\text { FIESP- Federação das } \\
\text { Indústrias do Estado de } \\
\text { São Paulo }\end{array}$ & $\begin{array}{l}\text { Movimento Popular de } \\
\text { Saúde da Zona Centro }\end{array}$ & $\begin{array}{l}\text { ACELBRA - Associação } \\
\text { dos Celíacos do Brasil }\end{array}$ \\
\hline Força Sindical & $\begin{array}{l}\text { Movimento Popular de } \\
\text { Saúde da Zona Norte }\end{array}$ & $\begin{array}{l}\text { APAF - Associação de } \\
\text { Pais e Amigos de } \\
\text { Fenilcetonúricos }\end{array}$ \\
\hline \multirow[t]{6}{*}{ Universidade Mackenzie } & $\begin{array}{c}\text { Movimento Popular de } \\
\text { Saúde da Região } \\
\text { Oeste }\end{array}$ & $\begin{array}{c}\text { APAS - Associação } \\
\text { Paulista de } \\
\text { Supermercados }\end{array}$ \\
\hline & $\begin{array}{l}\text { Movimento Popular de } \\
\text { Saúde da Região } \\
\text { Sudeste }\end{array}$ & $\begin{array}{c}\text { APRAG - Associação } \\
\text { dos Controladores de } \\
\text { Vetores e Pragas } \\
\text { Urbanas }\end{array}$ \\
\hline & $\begin{array}{l}\text { Movimento Popular de } \\
\text { Saúde da Zona Sul }\end{array}$ & Associação Ten Yad \\
\hline & $\begin{array}{c}\text { Sindicato das } \\
\text { Indústrias Químicas, } \\
\text { Farmacêuticas, } \\
\text { Plásticas e Similares } \\
\text { de São Paulo e região }\end{array}$ & $\begin{array}{l}\text { Instituto Pólis- } \\
\text { Instituto de Estudos, } \\
\text { Formação e Assessoria } \\
\text { em Políticas Sociais }\end{array}$ \\
\hline & & $\begin{array}{l}\text { SINDIPAN - Sindicato } \\
\text { da Indústria de } \\
\text { Panificação e } \\
\text { Confeitaria de } \\
\text { São Paulo }\end{array}$ \\
\hline & & $\begin{array}{c}\text { UNINOVE - } \\
\text { Universidade Nove de } \\
\text { Julho }\end{array}$ \\
\hline
\end{tabular}


Não foi possível obter informações detalhadas quanto às características de duas das entidades representadas pelos membros da sociedade civil no CADES - CREA e Universidade Mackenzie - e de uma do COMUSAN - UNINOVE.

Figura 6 - Caracterização das entidades e/ou associações representadas pelos conselheiros entrevistados no Conselho Municipal do Meio Ambiente e Desenvolvimento Sustentável (CADES), São Paulo, 2006 e 2007.

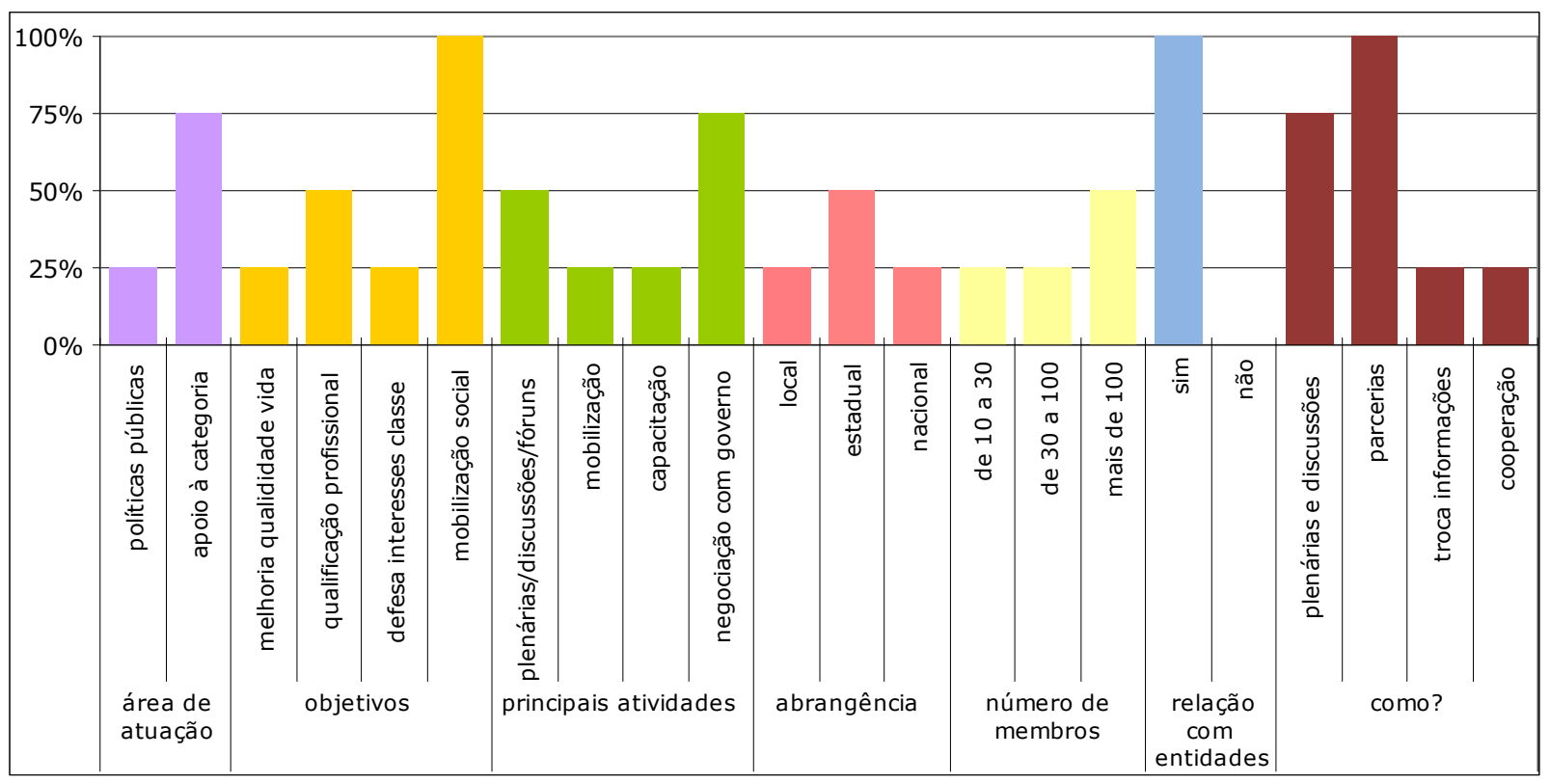

Entre os entrevistados do CADES que representam entidades, todos fazem parte da sua direção ou da sua coordenação e participam há mais de cinco anos da entidade e/ou associação.

Como seria esperado, a entidade que representa uma associação de moradores de um bairro específico da cidade (Associação dos Moradores do Jardim Saúde) tem como abrangência de atuação o nível local, apesar de ser a única que refere ter como área de atuação as políticas públicas e estabelecer relações com movimentos ligados à questão urbana e à habitação, 
o que tem a ver com a especificidade do Conselho Municipal de Meio Ambiente e Desenvolvimento Sustentável.

A entidade que atua na área sindical (Força Sindical) tem abrangência nacional. Sua origem está ligada às mobilizações sindicais e, assim, sua área de atuação é o apoio às categorias de trabalhadores e grupos sociais que a compõem e seu objetivo principal é a defesa de interesses de classe, o que acaba por incluir a luta pela melhoria da qualidade de vida.

As outras duas têm abrangência estadual e são representativas da área de comércio - Federação do Comércio do Estado de São Paulo (FECOMÉRCIO) - e indústria - Federação das Indústrias do Estado de São Paulo (FIESP) -.

Todas essas três entidades referem como área de atuação principal o fortalecimento e apoio à categoria profissional ou grupo social vinculado à entidade $(75 \%)$ e as atividades desenvolvidas mais citadas são negociação com o governo (75\%) e plenárias, discussões e fóruns (50\%).

Cada uma das entidades tem relações, exclusivamente, com outras que têm a mesma área de atuação, por meio do estabelecimento de parcerias para a realização de projetos comuns, além de reuniões conjuntas: a Força Sindical com outros sindicatos e representações de trabalhadores e de apoio e fortalecimento a grupos sociais específicos, a Associação dos Moradores do Jardim da Saúde com um instituto que também atua na área ambiental, a FECOMERCIO com outras associações comerciais e a FIESP com outras entidades representantes de indústrias. 
Figura 7 - Relações estabelecidas entre as entidades presentes no Conselho Municipal do Meio Ambiente e Desenvolvimento Sustentável e outras entidades e/ou associações, São Paulo, 2006 e 2007.



AMJS $\longrightarrow$ Instituto de Proteção Ambiental (PROAM)

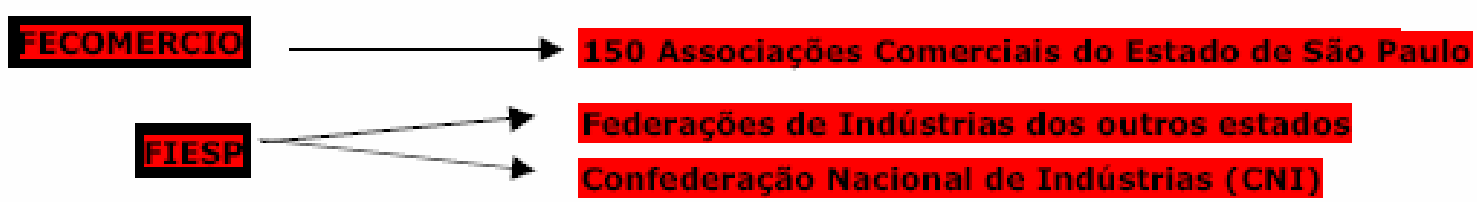

Legendas
Área de atuação da entidade
Políticas públicas
Apoio e fortalecimento à categoria profissional/ grupo social/ entidade
Entidades que participam do Conselho

Siglas:

AMJS - Associação de Moradores do Jardim Saúde

FECOMÉRCio - Federação do Comércio do Estado de São Paulo

FIESP - Federação das Indústrias do Estado de São Paulo 
Dos membros do CMS que representam entidades e/ou associações, $44,4 \%$ faz parte da direção ou coordenação das mesmas e $55,6 \%$ é associado e a maioria (75\%) atua na entidade e/ou associação há mais de cinco anos.

Figura 8 - Caracterização das entidades e/ou associações representadas pelos conselheiros entrevistados no Conselho Municipal de Saúde (CMS), São Paulo, 2006 e 2007.

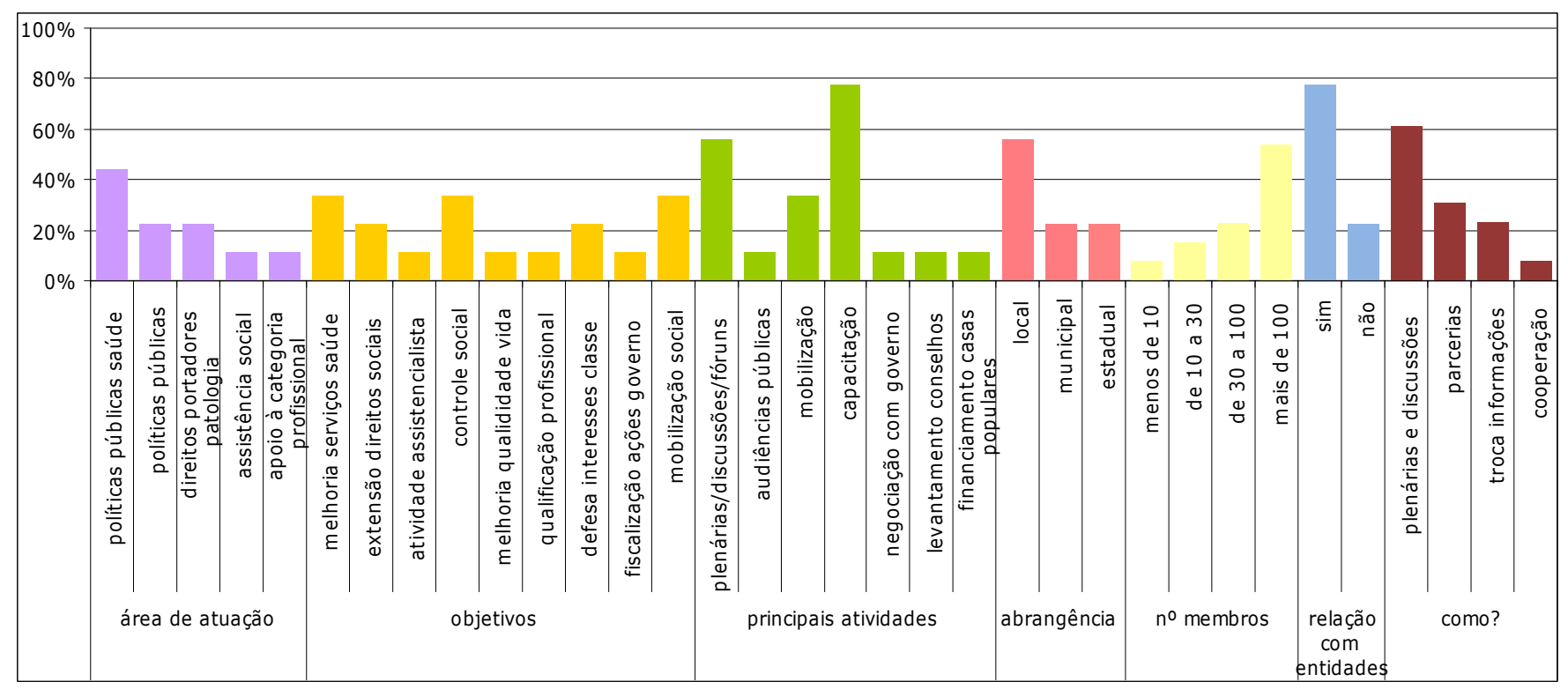

As associações e entidades também têm um caráter diverso, suas atuações concentram-se, principalmente, em políticas públicas de saúde $(44,4 \%)$, políticas públicas em geral $(22,2 \%)$, direitos de portadores de deficiências $(22,2 \%)$ e fortalecimento e apoio à categoria profissional, grupo social ou entidade (11,1\%) e assistência social $(11,1 \%)$. Os principais objetivos citados são a melhoria da qualidade dos serviços de saúde $(33,3 \%)$, controle social $(33,3 \%)$, mobilização social $(33,3 \%)$, extensão dos direitos sociais $(22,2 \%)$ e defesa dos interesses de classe $(22,2 \%)$, por meio atividades de capacitação $(77,8 \%)$, de plenárias, discussões e fóruns $(55,6 \%)$ e atividades de mobilização como reivindicações, 
atos públicos e abaixo assinados (33,3\%).

As entidades representadas pelo segmento da sociedade civil no CMS representam entidades que trabalham voluntariamente, por acreditarem que a melhoria da qualidade de saúde de seu bairro e do país é importante e possível.

Das nove entidades, cinco são movimentos populares de regiões específicas do município de São Paulo (Movimento Popular de Saúde da Zona Centro, Movimento Popular de Saúde da Zona Norte, Movimento Popular de Saúde da Região Oeste, Movimento Popular de Saúde da Região Sudeste e Movimento Popular de Saúde da Zona Sul); todos esses têm abrangência local, o que é mais característico de associações desse tipo que mobilizam a população de bairros próximos em torno de questões, em geral, mais setorizadas. As duas entidades com abrangência municipal são um sindicato (Sindicato dos Trabalhadores das Indústrias Químicas e Similares de São Paulo e região) e um conselho municipal (Conselho Municipal da Pessoa Portadora de Deficiência) e as de abrangência estadual são uma organização nãogovernamental (Ação da Cidadania São Paulo) e uma associação que tem como objetivo agregar e representar as associações com mesmo perfil no Estado (Federação das Associações Comunitárias do Estado de São Paulo).

No CMS, as entidades e/ou associações estão, majoritariamente (seis em nove, ou 66,6\%), ligadas a movimentos sociais relacionados com a participação popular e a gestão pública, sendo que seis dessas, explicitamente, também pertencem aos movimentos populares da área da saúde. Os representantes de três dessas entidades referiram como um dos seus objetivos a melhoria dos serviços de saúde e os das outras três indicaram o controle social. 
A maior parte $(60 \%)$ dos entrevistados representantes do segmento da sociedade civil faz parte da direção ou coordenação da entidade e/ou associação que representa no Conselho. Com relação aos representantes dos trabalhadores, essa porcentagem sobe para $66,7 \%$.

Ou seja, há uma tendência das instituições de indicarem os que exercem papel de liderança no seu meio para sua representação, já apontando certa concentração de poder.

Destaca-se que são os movimentos populares da área das políticas públicas da saúde que mantém mais relações entre si e com duas outras entidades que atuam com políticas públicas em geral e que aglutinam várias outras associações. As outras entidades de representação sindical e de portadores de deficências estabelecem vínculos exclusivamente com entidades com mesmo perfil e coincidência de áreas de atuação e objetivos. 
Figura 9 - Relações estabelecidas entre as entidades presentes no Conselho Municipal de Saúde e outras entidades e/ou associações, São Paulo, 2006 e 2007.

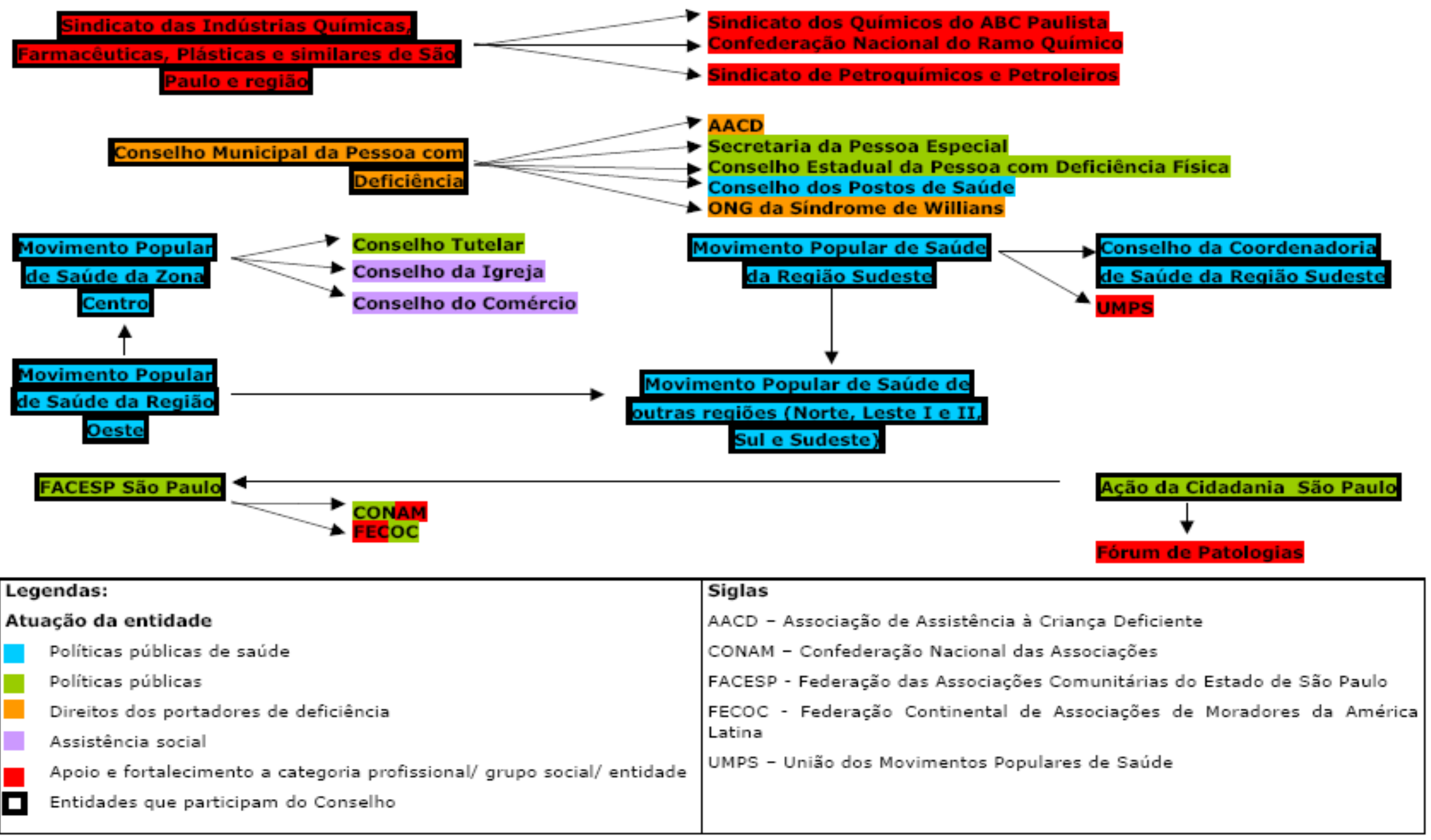


No COMUSAN, a área de atuação voltada para a capacitação profissional é apontada por $20 \%$ das entidades e/ou associações presentes, assim como o apoio à categoria profissional. Isso está relacionado com as características da composição do conselho que é amplamente constituído por profissionais da área.

A área de assistência social foi apontada por 30\% das entidades. Destaca-se que as outras áreas de atuação indicadas foram: políticas públicas $(20 \%)$ e direito de portadores de deficiências e patologias (20\%). Cabe registrar que, muitas vezes, comprometimentos de saúde estão relacionados com a ingestão ou não de determinados alimentos.

O tipo de atuação confirma-se ao se analisar os objetivos principais das entidades. Os objetivos de extensão dos direitos sociais - que estão vinculadas com os portadores de deficências ou patologias e ONG's - e a mobilização social foram apontados por $40 \%$ das entidades presentes. Qualificação profissional foi indicada por $30 \%$ e defesa dos interesses de classe por $50 \%$.

Considerando-se novamente 0 estudo feito junto aos membros da gestão 2004-2007 do CONSEA, verifica-se que ali havia predominância de organizações não-governamentais e entidades patronais e sindicais com atuações também vinculadas às áreas de capacitação, educação e direitos sociais, o que parece agregar os militantes e interessados na temática (COSTA, 2008). 
Figura 10 - Caracterização das entidades e/ou associações representadas pelos conselheiros entrevistados no Conselho Municipal de Segurança Alimentar e Nutricional (COMUSAN), São Paulo, 2006 e 2007.

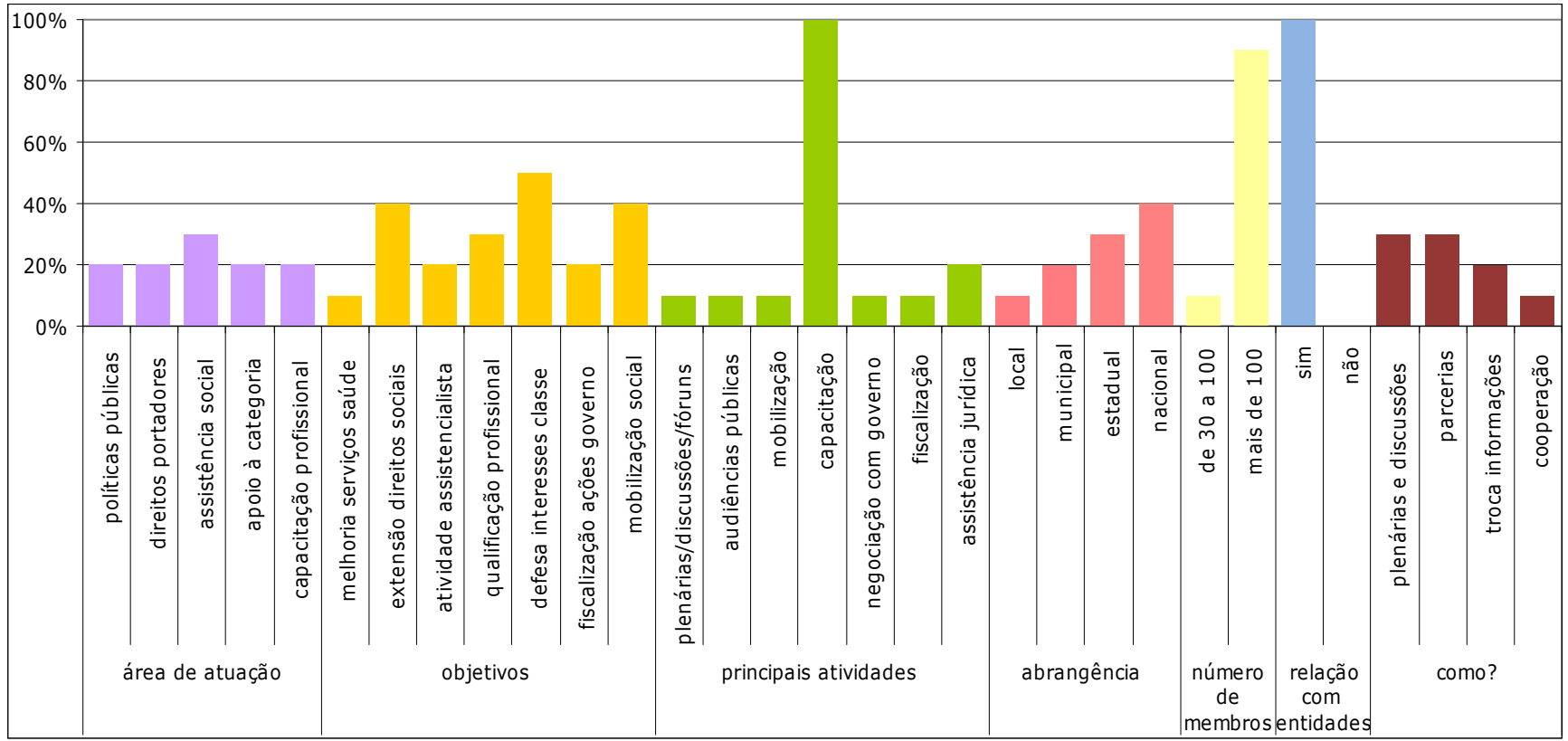

No caso do COMUSAN, as associações e/ou entidades que atuam nos níveis local e municipal são minoria. Uma tem abrangência local, que é uma associação de bairro (Associação Beneficente Vila Araguaia e adjacências) e duas têm abrangência municipal, que são uma organização não-governamental com atuação na área da assistência social (Ten Yad) e um sindicato de profissionais da área de alimentação (Sindicato da Indústria de Panificação e Confeitaria de São Paulo). As outras sete entidades têm abrangência estadual (três) ou nacional (quatro).

As entidades e/ou associações representadas no COMUSAN estão vinculadas a movimentos do campo mais genérico dos direitos e da educação. Destaca-se que uma das entidades, que é uma Organização Não Governamental (ONG), vincula-se ao movimento das cooperativas populares, o que faz sentido, considerando-se que muitas das práticas das entidades da área de 
segurança alimentar e nutricional relacionam-se com a produção e distribuição de alimentos de forma alternativa que são viabilizadas por cooperativas em que diferentes associações se articulam.

Todas as entidades e associações participantes possuem relação com outras associações, conselhos e entidades, por meio de parcerias em programas, cursos, treinamentos. 
Figura 11 - Relações estabelecidas entre as entidades presentes no Conselho Municipal de Segurança Alimentar e Nutricional e outras entidades e/ou associações
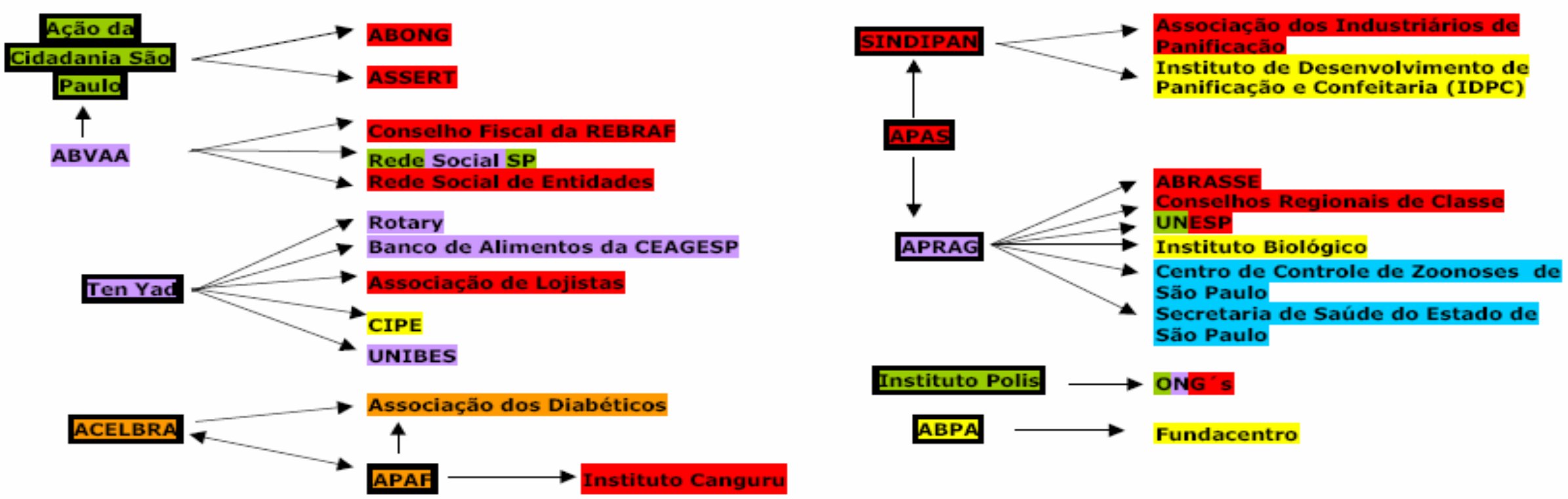

\begin{tabular}{|c|c|}
\hline $\begin{array}{l}\text { Legenda: } \\
\text { Atuação da entidade } \\
\text { Políticas públicas de saúde } \\
\text { Políticas públicas } \\
\text { Direitos dos portadores de deficiência } \\
\text { Assistência social } \\
\text { Apoio e fortalecimento a categoria profissional/ grupo social/ entidade } \\
\text { Capacitação profissional } \\
\text { Entidades que participam do Conselho }\end{array}$ & $\begin{array}{l}\text { Siglas: } \\
\text { ABONG - Associação Brasileira de Organizaç̃es Não Governamentais } \\
\text { ABPA - Associação Brasileira de Prevenção de Acidentes } \\
\text { ABRASSE - Associação Brasileira de Apoio ao Setor de Serviços } \\
\text { ABVAA - Associação Beneficente Vila Araguaia e Adjacências } \\
\text { ACELBRA - Assoçação dos Celíacos do Brasil } \\
\text { APAF - Associaçãoo de Pais e Amigos de Fenilcetonúricos } \\
\text { APAS- Associação Paulista de Supermercados } \\
\text { APRAG - Associação dos Controladores de Vetores e Pragas Urbanas } \\
\text { ASSERT - Associação dos Servidores e Funcionários Públicos do Estado de São Paulo } \\
\text { CEAGESP - Companhia de Entrepostos e Armazéns Gerais de São Paulo } \\
\text { CIPE - Centro de Informações Profissionais e Estudantis } \\
\text { Fundacentro- Fundação Jorge Duprat Figueiredo de Segurança e Medicina do Trabalho } \\
\text { Instituto Pólis- Instituto de Estudos, Formação e Assessoria em Políticas Sociais } \\
\text { REBRAF - Rede Brasileira de Entidades Assistenciais Filantrópicas } \\
\text { SINDIPAN - Sindicato da Indústria de Panificação e Confeitaria de São Paulo } \\
\text { UNESP - Universidade Estadual de São Paulo } \\
\text { UNIBES - União Brasileiro-Israelita do Bem-Estar Social }\end{array}$ \\
\hline
\end{tabular}


Em geral, as relações são unidirecionais, ou seja, as setas saem das entidades presentes no Conselho para outras que estão fora mas, não necessariamente, atuam exclusivamente na mesma área. É possível observar que as duas entidades que tratam da questão específica de portadores de patologias têm relações entre si (ACELBRA - Associação dos Celíacos do Brasil e APAF Associação de Pais e Amigos dos Fenilcetonúricos do Estado de São Paulo) e com outra (Associação dos Diabéticos) que não está presente no Conselho mas tem o mesmo tipo de atuação ligada a outra patologia que requer abordagem própria quanto à alimentação e atenção à saúde. A ONG que tem como área de atuação a assistência social e tem cunho religioso (Ten Yad) relaciona-se, basicamente, com entidades fora do Conselho que são assistenciais (Rotary, Banco de Alimentos da Ceagesp, Associação de Lojistas) e religiosas, especificamente CIPE e Unibes, e que a apóiam na realização das suas atividades assistenciais.

A maioria das associações e entidades presentes no CADES, CMS e COMUSAN, possuem algum tipo de relação com outras entidades e/ou associações que estão fora dos Conselhos, mas que têm objetivos e interesses similares, por meio de parcerias, realização de projetos conjuntos, troca de informações e cooperação. É no CMS que há maior número de referências a relações entre as próprias entidades que compõem o conselho.

O fato da maior parte das relações ser estabelecida com associações que não estão presentes nos Conselhos pode ser um bom indicador da capilaridade que os fóruns participativos podem atingir, ampliando o alcance das discussões e a abrangência de possível interferência ou, pelo menos, de acompanhamento das discussões relativas às políticas públicas de interesse. Isso tem a 
ver com o potencial das associações no desenvolvimento de mecanismos de articulação com outras organizações, de caráter similar, no sentido de ampliar o olhar de cada uma delas - e, assim, cumprir um papel educativo fundamental - e, principalmente, de fazer com que diferentes grupos consigam se representar (JUNQUEIRA, 2002).

Para Scherer-Warren, a noção de rede diz respeito a uma nova forma de organização e de ação, interessante para o estudo dos movimentos sociais. Para essa autora

[...] subjacente a essa idéia encontra-se, pois, uma nova visão do processo de mudança social - que considera fundamental a participação cidadã - e da forma de organização dos atores sociais para conduzir esse processo (SCHERER-WARREN, 1999, p. 24).

Há formas diferentes para a definição do membro que ocupará a vaga no CADES, entre as entidades escolhidas para representarem o segmento da sociedade civil. No caso dos conselheiros entrevistados, tem-se que em três delas (FECOMÉRCIO, FIESP e Força Sindical) a pessoa foi indicada e em uma delas foi voluntária (Associação de Moradores do Jardim Saúde) e em duas das entidades (CREA e Universidade Mackenzie) não há uma regra definida para essa indicação.

Para ocuparem as vagas no CMS, os quatro representantes do segmento dos trabalhadores foram eleitos por seus pares, dentro das entidades e/ou associações que representam. Entre os usuários, sete foram eleitos (Movimento Popular de Saúde da Zona Centro, Movimento Popular de Saúde da Região Oeste, Movimento Popular de Saúde da Região Sudeste e Movimento Popular de Saúde da Zona Sul, Sindicato dos Trabalhadores de Indústrias Químicas e Similares de São Paulo e região; Federação das Associações Comunitárias do Estado de São Paulo e Conselho 
Municipal da Pessoa Portadora de Deficiência), e dois se voluntariaram para isso (Movimento Popular de Saúde da Zona Norte e Ação da Cidadania São Paulo).

Desde a criação do Conselho Municipal de Saúde, sempre coube aos movimentos e associações e/ou entidades a indicação das pessoas para ocupar as vagas destinadas aos representantes dos usuários, em geral, por meio da promoção de eleições que são divulgadas e acompanhadas por técnicos do sistema de saúde. Após esse processo há uma reunião aberta para a formalização dos mandatos (COELHO e VERÍSSIMO, 2004).

No COMUSAN, entre os representantes do segmento dos trabalhadores, um foi eleito por seus pares (Sindicato dos Agentes Vistores), um foi indicado (Associação Brasileira de Engenharia de Alimentos) e quatro se voluntariaram para representar sua entidade (Sindicato dos Médicos Veterinários, Conselho Regional de Nutrição, Associação Paulista de Nutrição e Sindicato dos Nutricionistas do Estado de São Paulo). Entre os representantes da sociedade civil, seis foram indicados (Associação Paulista de Supermercados, Ação da Cidadania São Paulo, Associação Beneficente Vila Araguaia e Adjacências, Associação dos Celíacos do Brasil, Centro Universitário Nove de Julho e Associação dos Controladores de Vetores e Pragas Urbanas), quatro foram voluntários para exercer a representação da entidade (Instituto Pólis, Associação de Pais e Amigos de Fenilcetonúricos do Estado de São Paulo, SINDIPAN e Ten Yad) e apenas um foi eleito por seus pares (Associação Brasileira de Prevenção de Acidentes). Talvez por ser um conselho bastante recente (foi regulamentado em 2003) e porque segurança alimentar e nutricional é um tema novo e pouco disseminado, não se percebe grande envolvimento da 
população para eleger membros para a composição do Conselho, prevalecendo as indicações.

Figura 12 - Distribuição das entidades e/ou associações representadas pelos conselheiros entrevistados no Conselho Municipal do Meio Ambiente e Desenvolvimento Sustentável (CADES), no Conselho Municipal de Saúde (CMS) e no Conselho Municipal de Segurança Alimentar e Nutricional (COMUSAN) e em todos os Conselhos Municipais, segundo área de atuação e objetivos principais, São Paulo, 2006 e 2007.

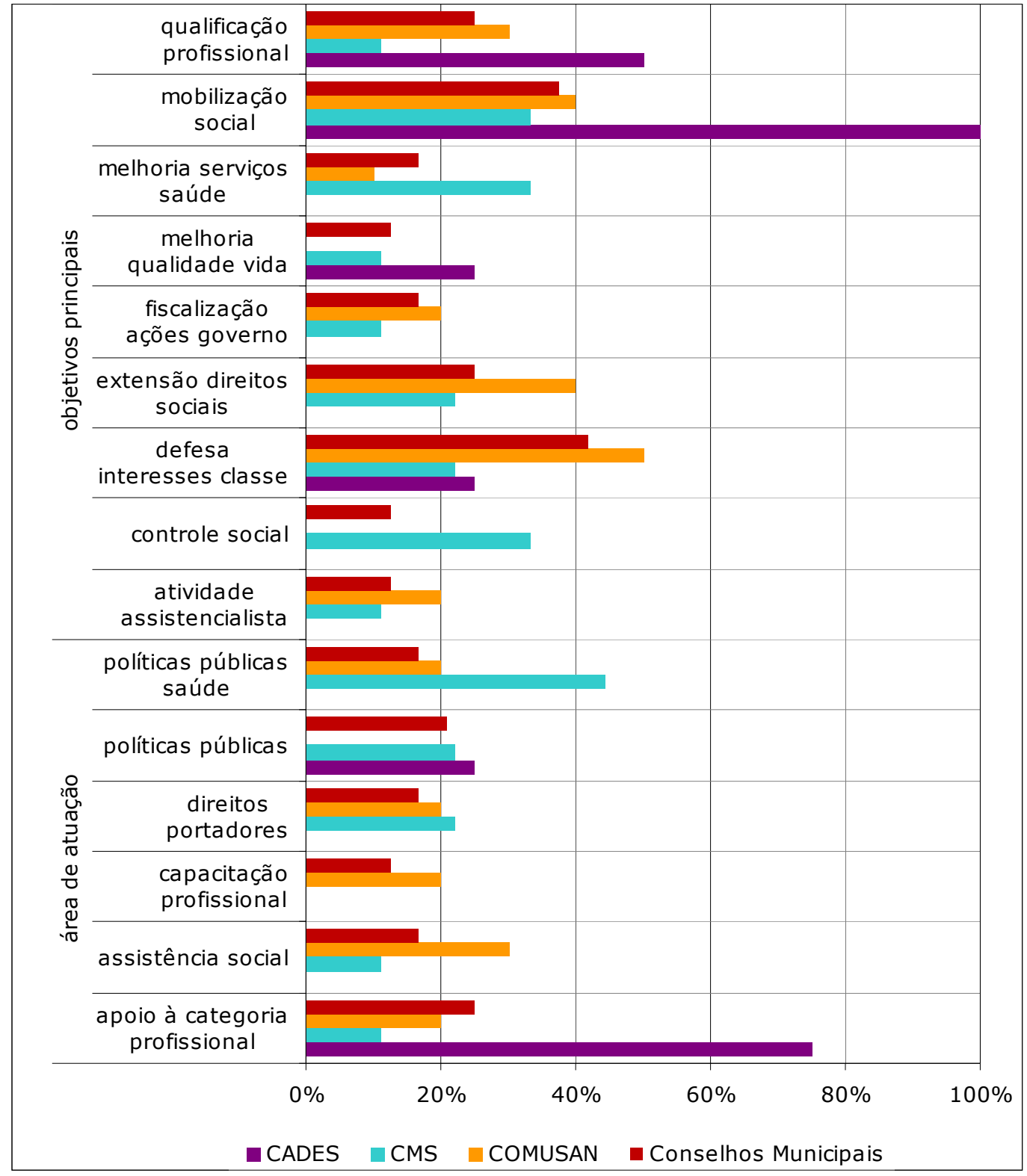


Ao se considerar todas as entidades e/ou associações identificadas nos Conselhos Municipais de Meio Ambiente e Desenvolvimento Sustentável, de Saúde e de Segurança Alimentar e Nutricional, verifica-se que $25 \%$ delas tem como área de atuação - apoio e fortalecimento à categoria profissional/grupo social/entidade e $20 \%$ refere a área de políticas públicas em geral. Também aparecem com destaque $(16,7 \%)$ as áreas de direitos dos portadores de deficiência e a assistência social.

Quanto aos objetivos, a defesa dos interesses de classe e/ou grupos sociais específicos é o que mais aparece $(41,7 \%)$, muito como conseqüência das entidades presentes no COMUSAN (ligadas a categorias profissionais ou portadores de deficiências ou patologias). A seguir, aparecem a mobilização social $(37,5 \%)$ e a extensão dos direitos sociais e a qualificação profissional com $25 \%$ cada um.

Observou-se que aproximadamente $37,5 \%$ das entidades representantes do segmento da sociedade civil que foram caracterizadas estavam ligados a organizações típicas de associativismo comunitário (nove entidades) ou religioso (uma entidade). Apesar de não corresponder à maior parte das entidades, é um número significativo, levando em conta a abrangência dos conselhos municipais em uma cidade da dimensão de São Paulo. Há correspondência, em termos percentuais, com os dados encontrados pela pesquisa Monitoramento e Apoio à Gestão Participativa do SUS (MOREIRA e col., 2008) que identificou que cerca de 30\% das entidades representantes do segmento dos usuários nos Conselhos Municipais de Saúde dos municípios com mais de cem mil habitantes pertence às categorias: associações de moradores, associações comunitárias e grupos religiosos. 
É preciso não perder de vista que entidades dos tipos referidos têm composto o grupo dos movimentos urbanos brasileiros desde os anos de 1970 quando se iniciaram, no período da ditadura militar, mobilizações mais intensas, em especial na área da saúde. Ou seja, esses grupos permanecem importantes e revelam um caráter de longevidade relevante.

\section{Participação e políticas públicas}

De forma geral, a maioria $(65,5 \%)$ dos membros entrevistados dos conselhos municipais considera que os Conselhos, enquanto instâncias de participação institucionalizadas, influenciam na formulação e implementação de políticas públicas, mas é preciso destacar que uma porcentagem significativa (31\%) aponta a não influência.

Figura 13 - Distribuição da percepção dos conselheiros entrevistados do Conselho Municipal do Meio Ambiente e Desenvolvimento Sustentável (CADES), do Conselho Municipal de Saúde (CMS) e do Conselho Municipal de Segurança Alimentar e Nutricional (COMUSAN) quanto à influência do Conselho na formulação e implantação de políticas públicas, segundo segmento, São Paulo, 2006 e 2007.

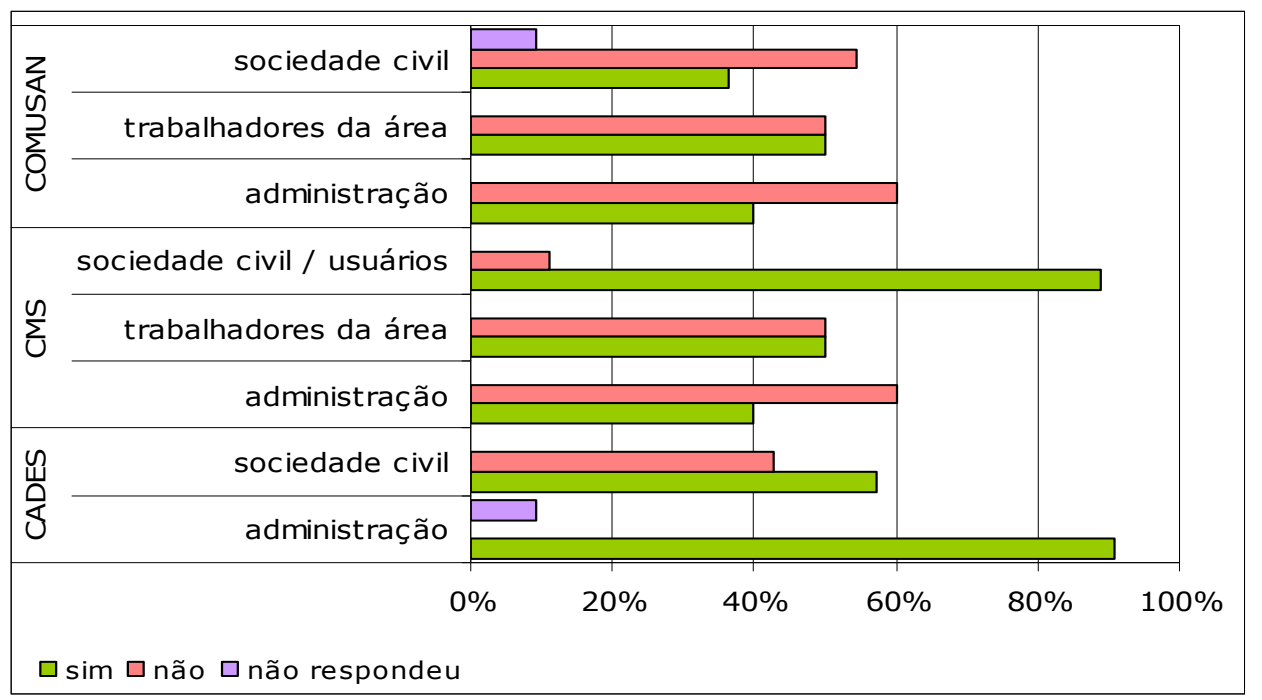


Figura 14 - Distribuição da percepção dos conselheiros entrevistados do Conselho Municipal do Meio Ambiente e Desenvolvimento Sustentável (CADES), do Conselho Municipal de Saúde (CMS) e do Conselho Municipal de Segurança Alimentar e Nutricional (COMUSAN) quanto à forma de influência do Conselho na formulação e implantação de políticas públicas, segundo segmento, São Paulo, 2006 e 2007.

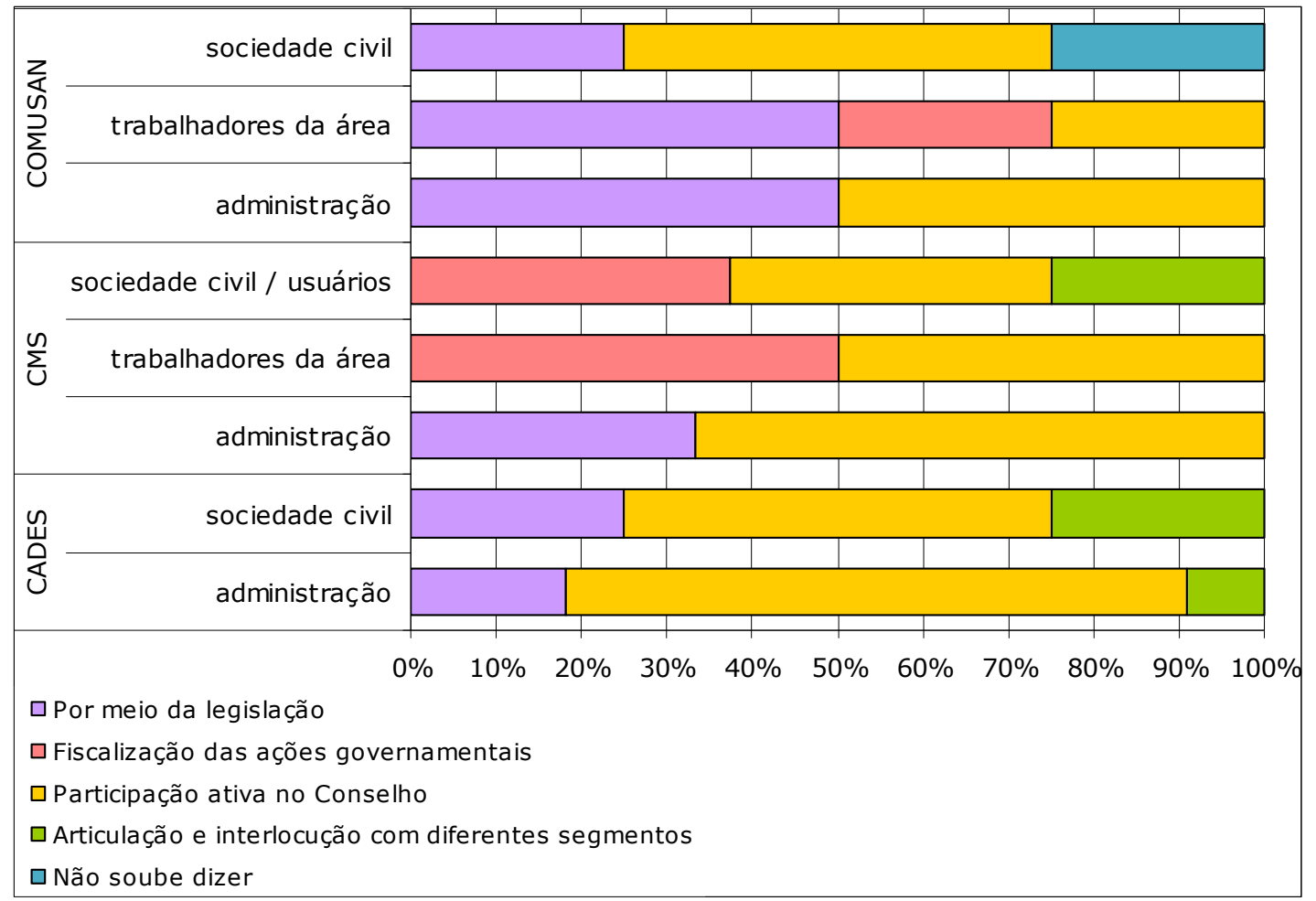

Os membros do segmento da administração do CADES mostram-se mais confiantes $(90,9 \%)$ quanto à influência que o Conselho exerce na formulação e implementação de políticas públicas, do que os membros do segmento da sociedade civil $(57,1 \%)$. As formas de influência mais destacadas foram a participação ativa no conselho $(66,7 \%)$, por meio da legislação (20\%) e a articulação e interlocução com diferentes segmentos $(13,3 \%)$.

Os conselheiros do segmento dos usuários do CMS têm uma percepção mais positiva $(88,9 \%)$ sobre a influência do Conselho na 
formulação e implementação de políticas públicas do que os outros segmentos - administração (40\%) e trabalhadores (50\%). A forma de influência mais identificada, em todos os segmentos, foi a participação ativa no conselho por meio da discussão das propostas e encaminhamentos deliberados - 66,6\% (segmento da administração), $50 \%$ (segmento dos trabalhadores) e $37,5 \%$ (segmento da sociedade civil).

Aqui vale considerar que os Conselhos de Saúde são os mais antigos e surgiram como conseqüência da grande mobilização dos movimentos sociais em saúde que participaram e tiveram forte influência na definição do Sistema Único de Saúde.

É interessante notar e destacar que no CMS, aparece, em segundo lugar, a questão da fiscalização das ações governamentais ( $50 \%$ e $37,5 \%$, respectivamente nos segmentos dos trabalhadores e da sociedade civil). Nesse caso, também é possível estabelecer uma relação com a própria origem dos conselhos de saúde que surgiram no bojo de ações fiscalizatórias que procuravam garantir o cumprimento do que era estabelecido por lei quanto à prestação dos serviços de saúde.

Em todos os segmentos do COMUSAN são baixos os índices de confiança na capacidade do Conselho em influenciar na formulação e implantação de políticas públicas: $60 \%$ da administração, $54,5 \%$ da sociedade civil e $50 \%$ dos trabalhadores. Com relação à forma como acontece essa influência, considerandose os membros dos três segmentos que referiram ocorrer influência, foram mais citadas: por meio da legislação (40\%) e por meio da participação ativa nas atividades do conselho (40\%).

A questão da capacidade de influência na definição das políticas públicas ou a própria elaboração das mesmas são pontos 
centrais em discussões feitas em torno da validade ou não da existência desses espaços participativos, considerando-se seu potencial limitado.

DAGNINO (2002) observa que é importante não fazer uma avaliação apressada dos espaços de participação da sociedade civil ou a partir de um ponto de vista equivocado que depositaria sobre tais espaços a responsabilidade de protagonizarem a transformação do Estado e da sociedade civil rumo a uma situação de democracia e cidadania plenas. Apesar do pouco acolhimento, pelo Estado, na implantação e implementação dos encaminhamentos resultantes das atividades desenvolvidas nos conselhos, essas instâncias participativas estão consolidadas e representam uma conquista da sociedade brasileira, fruto de processos históricos complexos e singulares, e têm servido, pelo menos, como canais de expressão de demandas e reivindicações que não podem mais ser completamente ignoradas pelo poder público, exercendo pressão sobre ele. Também servem como brechas para facilitar a incorporação de atores políticos, antes alijados dos processos de tomada de decisão, provocando certo desconforto à burocracia estatal, o que pode ser útil para maior democratização do sistema político e social como um todo, mesmo se considerando todas as restrições à efetividade dos conselhos como espaços deliberativos (FUKS e PERISSINOTTO, 2006).

Outro risco é supor que esses espaços públicos de participação da sociedade civil são arenas políticas abertas (DAGNINO, 2002) em que todos os participantes encontram-se em igualdade de condições para apresentar e argumentar em nome de suas propostas. Ou seja, não é possível desconsiderar que é preciso mais do que os conselhos e outros fóruns similares, pois 
são muitas e complexas as arenas de disputa, para se contrapor aos projetos políticos hegemônicos que representam os interesses de forças econômicas e políticas dominantes, além do fato de que não existe um único projeto político agregador que faça frente a tais forças dominantes.

Figura 15 - Distribuição do conhecimento dos conselheiros entrevistados do Conselho Municipal do Meio Ambiente e Desenvolvimento Sustentável (CADES), do Conselho Municipal de Saúde (CMS) e do Conselho Municipal de Segurança Alimentar e Nutricional (COMUSAN) sobre o funcionamento de outros conselhos gestores, segundo segmento, São Paulo, 2006 e 2007.

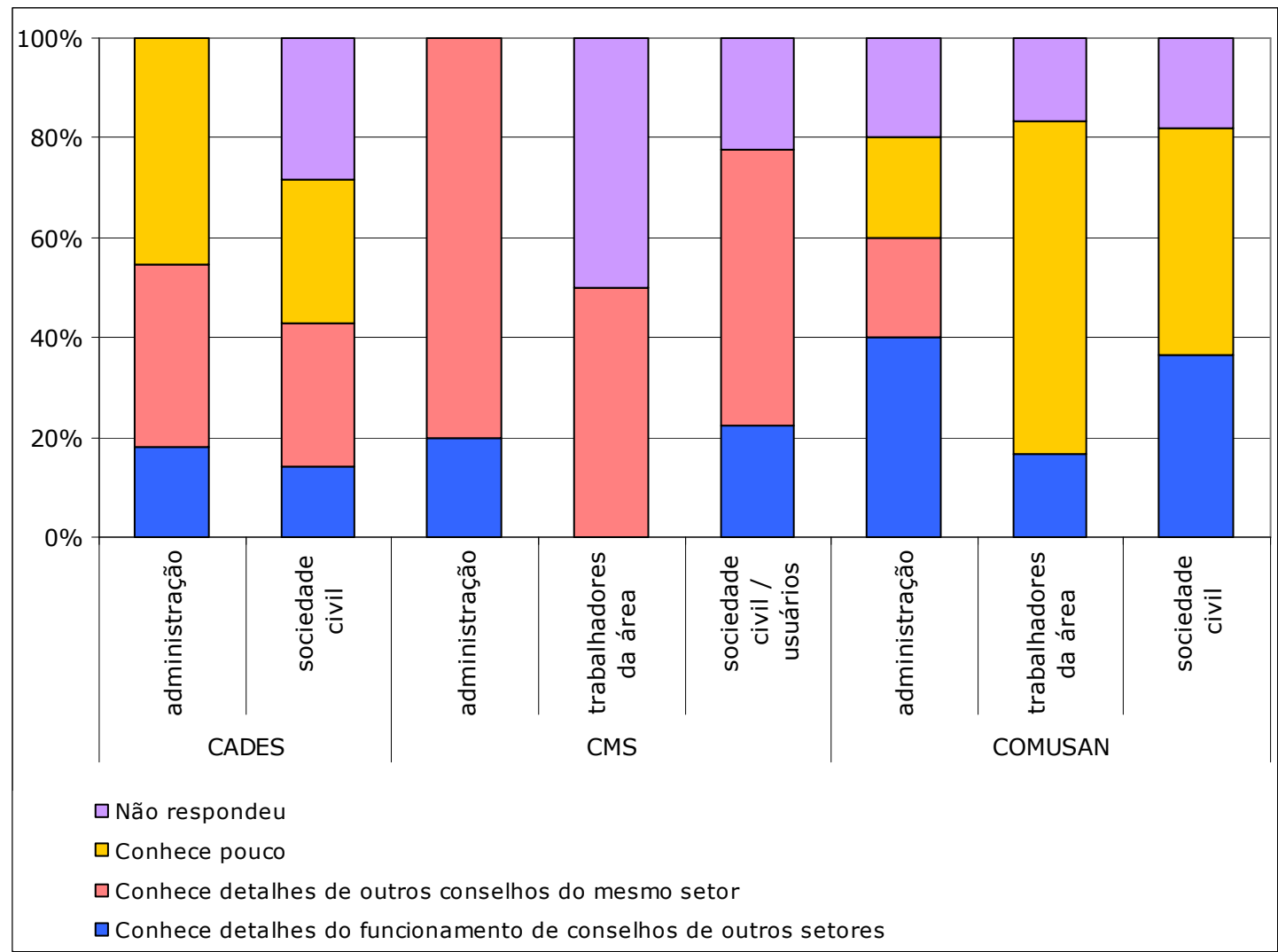

O conhecimento quanto ao funcionamento de outros conselhos - o que tem a ver com a facilitação de possíveis aproximações com fóruns participativos de discussão e tomada de 
decisão quanto à políticas públicas integradas - é pequeno e quando existe está restrito a conselhos do mesmo setor. Ou seja, esse é um indicador de que, apesar da manifestação de interesse quanto à articulação e proposição de políticas intersetoriais, há dificuldades e limitações em decorrência de desconhecimento e despreparo daqueles que teriam que estar mais habiltados para, ao menos, desencadear esse processo. Parece haver um descompasso entre a pretensão manifestada e a realização de ações concretas, por parte das associações e/ou entidades e seus membros, que possibilitem o alcance do almejado.

Isso também não pode ser tomado como responsabilidade única ou incompetência dos membros dos conselhos ou de seus responsáveis técnicos, pois, se analisarmos como são formuladas as políticas públicas no âmbito do Estado brasileiro, facilmente identificar-se-á a predominância de um modelo de gestão centralizado - no que diz respeito à formulação de políticas públicas, com a idéia de que isso garantiria uma implementação universal em todo o território nacional - e, ao mesmo tempo, com uma prática setorial e fragmentada na identificação e discussão dos principais problemas nacionais, com encaminhamentos de caráter pontual, emergencial e compensatório (DAGNINO, 2002).

Além disso, a própria institucionalização dos conselhos gestores deu-se segundo uma lógica setorial ou programática (saúde, educação, habitação, transporte, assistência social, esportes, meio ambiente, alimentação escolar, entre outros) e quando se organizaram segundo outros recortes - que envolvem uma integração de agendas, como, por exemplo, no caso da segurança alimentar e nutricional -, sempre aparece a dificuldade de a que ou a quem vinculá-los e isso se torna um problema 
operacional, como tem sido observado com relação ao COMUSAN de São Paulo que foi ligado a diferentes secretarias municipais, desde a sua criação.

Também como resultado da tradição política brasileira, temse constatado que o poder público dos municípios estabelece relações horizontais muito precárias com os espaços participativos e confere-Ihes pouco poder efetivo (ABERS e KECK, 2008). E essas relações entre o poder público e os conselhos ou outros fóruns de participação social variam conforme $o$ envolvimento $e$ comprometimento do gestor local ou municipal com a idéia de democratização e compartilhamento da gestão (COELHO e VERÍSSIMO, 2004).

Especificamente, os conselheiros de saúde, em estudo de LABRA e FIGUEREDO (2002), justificaram a pouca influência que tinham sobre as ações do Estado na área de saúde com o fato das autoridades não respeitarem o papel do Conselho de Saúde.

Pode-se considerar que os Conselhos Municipais de Meio Ambiente e Desenvolvimento Sustentável, de Saúde e de Segurança Alimentar e Nutricional têm forte recorte setorial, seguindo a tradição mais presente nos conselhos de políticas. Mesmo assim, há uma expectativa, tomando-se em conta as discussões mais recentes sobre descentralização e intersetorialidade no âmbito da gestão pública, que cada um deles também passe a olhar os problemas e as temáticas presentes em cada agenda de modo mais ampliado, identificando intersecções com outras áreas e setores, até mesmo em uma perspectiva de otimização de ações e recursos.

Dessa forma, a partir das questões "Qual a sua expectativa sobre a influência desse Conselho na formulação e implementação 
de políticas públicas integradas e intersetoriais?" e "Existem políticas públicas integradas e intersetoriais?", procurou-se conhecer, mesmo que de forma incipiente, qual a percepção dos entrevistados sobre isso.

Figura 16 - Distribuição da percepção dos conselheiros entrevistados do Conselho Municipal do Meio Ambiente e Desenvolvimento Sustentável (CADES), do Conselho Municipal de Saúde (CMS) e do Conselho Municipal de Segurança Alimentar e Nutricional (COMUSAN) quanto à influência do Conselho na formulação e implantação de políticas públicas integradas e intersetoriais, segundo segmento, São Paulo, 2006 e 2007.

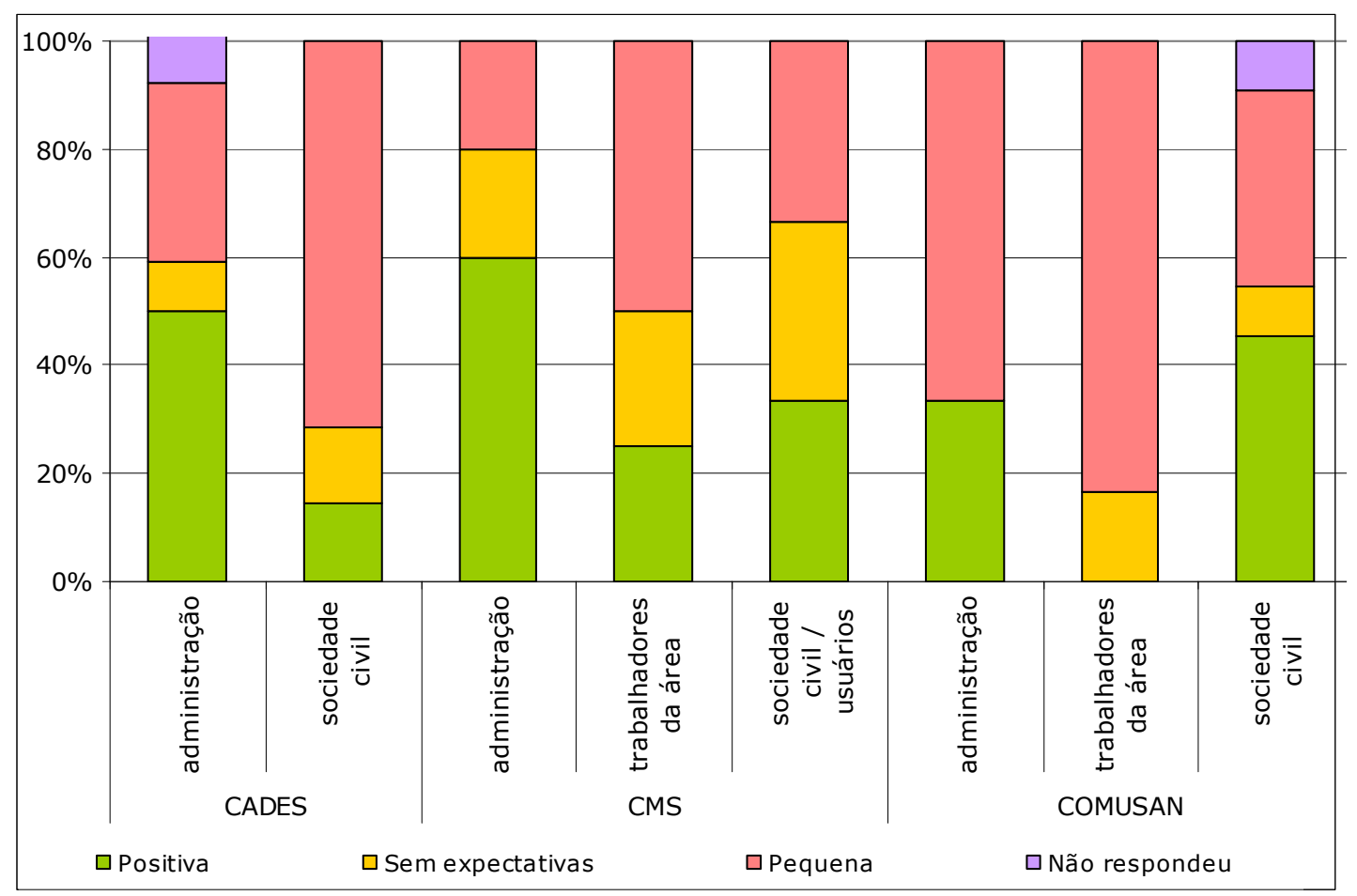

No CADES, a percepção do segmento da administração é bem mais positiva do que no segmento da sociedade civil, onde cerca de $70 \%$ dos conselheiros revelaram ter uma pequena expectativa quanto à influência do Conselho na formulação e implantação de políticas públicas integradas e intersetoriais. 
No COMUSAN, os conselheiros representantes da adminstração e dos trabalhadores da área também têm expectativa pequena, sendo o grupo da sociedade civil mais otimista.

Também no caso do CMS, é o segmento da administração o que tem mais crença na possibilidade de influência do Conselho na formulação de políticas públicas integradas e intersetoriais em oposição ao segmento dos trabalhadores da área.

Verifica-se que no CADES e no CMS, os membros da administração têm perspectiva mais otimista quanto à capacidade de influência do Conselho e que os representantes dos trabalhadores mostram-se mais pessimistas nos dois Conselhos em que participam. É interessante notar esta diferença de perpecpção entre esses dois segmentos, considerando que, no caso do CMS, os dois segmentos são compostos, predominantemente, por pessoas que trabalham no mesmo serviço público. Ao que parece os representantes dos trabalhadores percebem mais as limitações da instituição em que atuam.

Figura 17 - Distribuição da percepção dos conselheiros entrevistados dos Conselhos Municipais quanto à influência do Conselho na formulação e implantação de políticas públicas integradas e intersetoriais, São Paulo, 2006 e 2007.

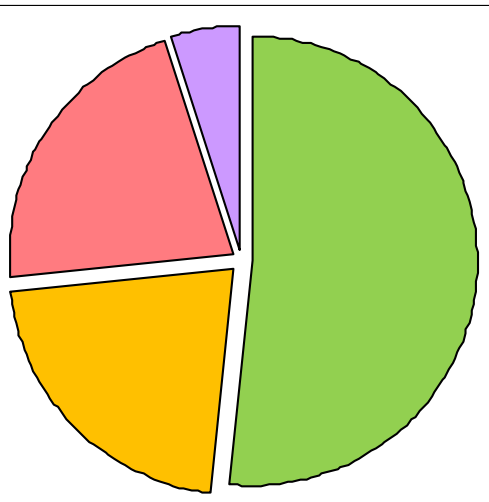

$\square$ Positiva $\square$ Sem expectativas $\square$ Pequena $\square$ Não respondeu 
Analisando-se, de forma conjunta, todas as respostas obtidas com relação à percepção de influência na formulação e implementação de políticas integradas e intersetoriais, tem-se que as expectativas são positivas apenas para $51,7 \%$ dos conselheiros entrevistados nos três Conselhos Municipais.

Para justificar suas percepções, os conselheiros fazem referência principalmente às dificuldades de integração e articulação entre os diferentes níveis e instâncias de governo, bem como entre as secretarias municipais $(23,73 \%)$, o que dificultaria o surgimento de idéias e discussões sobre políticas integradas, além disso, também aparecem a ausência de um plano estratégico de ação por parte dos conselhos $(6,78 \%)$ e a percepção de que os conselhos funcionam mais com um caráter consultivo do que deliberativo, independente das definições legais a respeito $(6,78 \%)$.

As justificativas revelam uma percepção bastante precisa das questões institucionais e administrativas envolvidas e do quanto elas podem ser ainda definidoras das práticas dos Conselhos. 
Figura 18 - Distribuição da percepção dos conselheiros entrevistados do Conselho Municipal do Meio Ambiente e Desenvolvimento Sustentável (CADES) quanto à existência de políticas intersetoriais e como foram formuladas e implantadas, segundo segmento, São Paulo, 2006 e 2007.

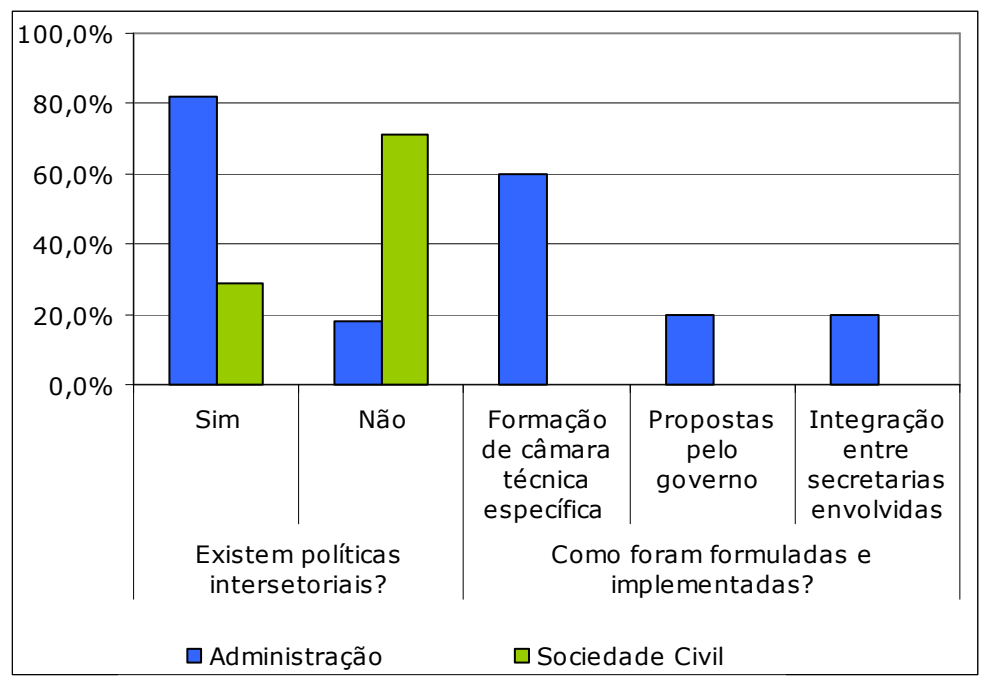

Figura 19 - Distribuição da percepção dos conselheiros entrevistados do Conselho Municipal de Saúde (CMS) quanto à existência de políticas intersetoriais e como foram formuladas e implantadas, segundo segmento, São Paulo, 2006 e 2007.

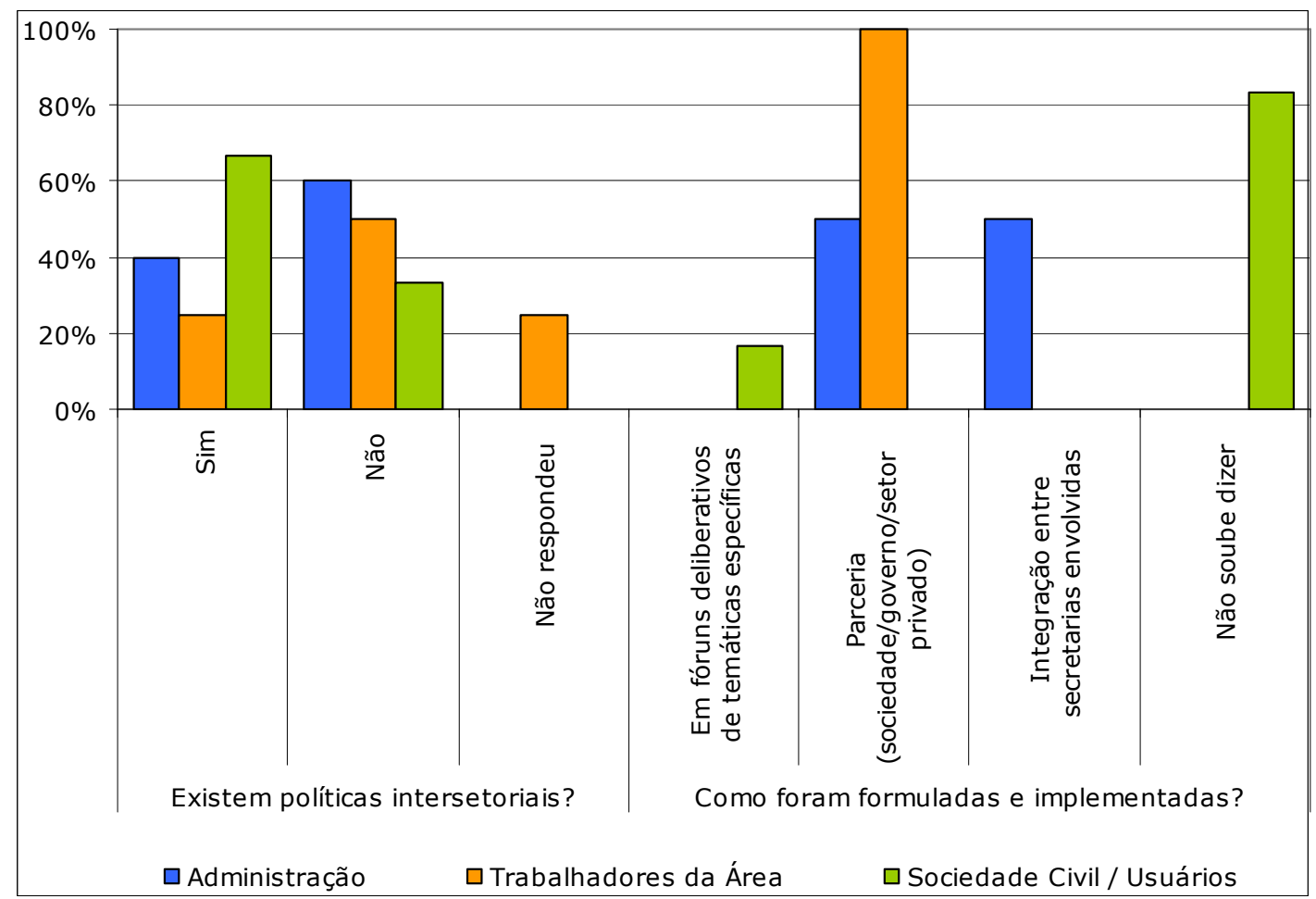


Figura 20 - Distribuição da percepção dos conselheiros entrevistados do Conselho Municipal de Segurança Alimentar e Nutricional (COMUSAN) quanto à existência de políticas intersetoriais e como foram formuladas e implantadas, segundo segmento, São Paulo, 2006 e 2007.

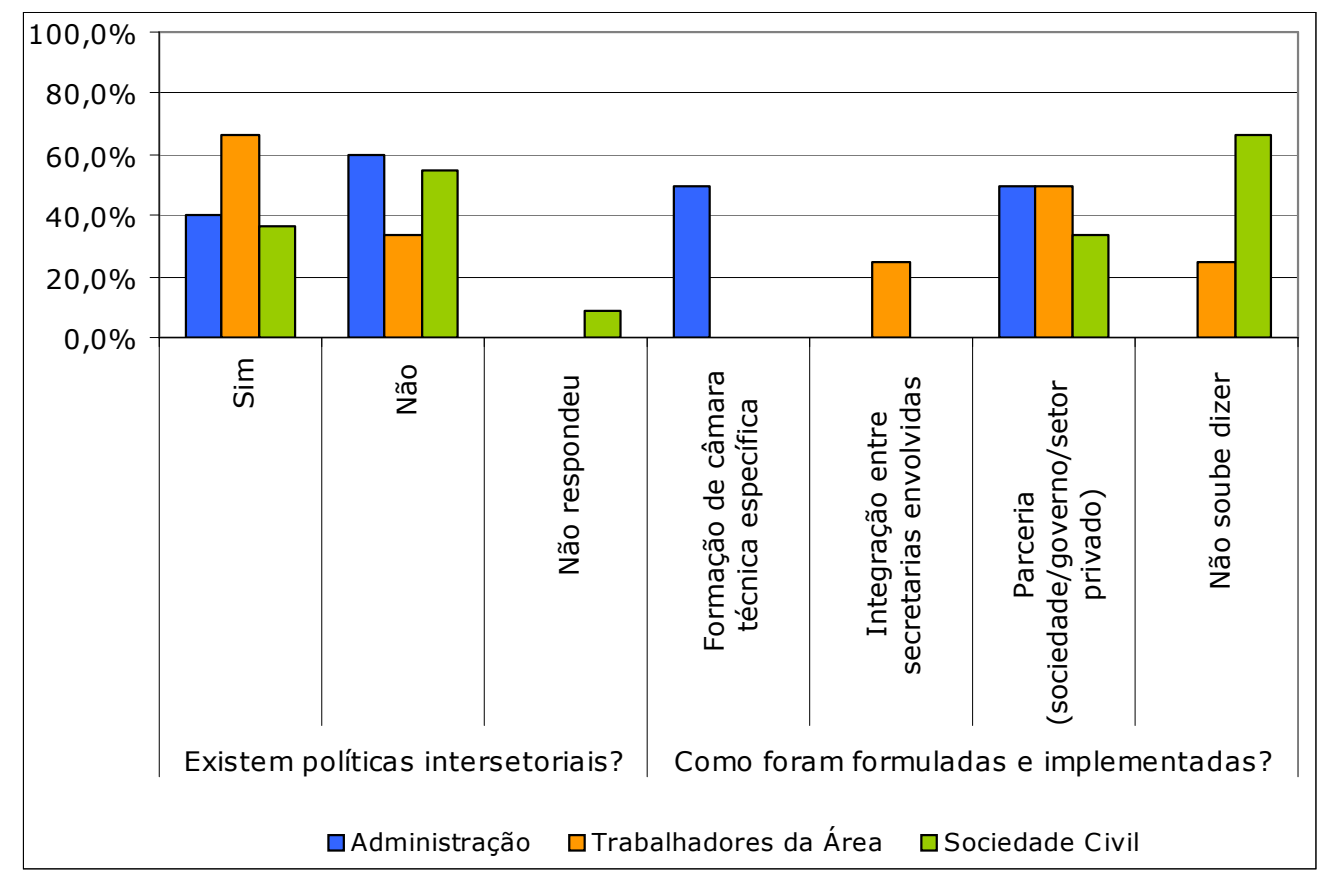

Quanto à existência de políticas intersetoriais, apenas 30 das 58 pessoas entrevistadas $(51,7 \%)$ respondeu que tais políticas existem. As mais mencionadas foram: Bolsa Escola, Plano Diretor, Preservação do Bororê, Gestão de Resíduos de Saúde, Operações Urbanas, Relatórios de Impacto de Vizinhança (referidas por membros do CADES); Programa de Saúde da Família, Saúde na Escola (referidas por membros do CMS) e Centro de Referência de Segurança Alimentar e Nutricional, Hortas Comunitárias, Programa de Alimentação Escolar, Restaurantes Populares, Semana da Saúde (referidas por membros do COMUSAN).

Sem se deter de forma aprofundada nas características das políticas públicas citadas, é possível dizer que há o entendimento de que política integrada pressupõe, pelo menos, trabalhar junto 
ou afetar com sua ação outros setores. Isso significa que há nesses fóruns um espaço fecundo para iniciar discussões e reflexões a respeito.

Com relação ao modo de formulação e implementação das mesmas, verificou-se precário conhecimento quanto aos procedimentos e foram mencionadas apenas algumas das possíveis etapas do processo de elaboração, mas nada foi referido quanto à implementação.

Entre todos os membros dos três Conselhos que responderam que existem políticas intersetoriais, $31 \%$ não soube dizer como foram formuladas. A integração entre secretarias foi citada por apenas $13,6 \%$; a formação de câmara técnica específica e a parceria entre governo, sociedade civil e o setor privado foram referidas por $23 \%$.

Isso é mais um aspecto dentre as dificuldades e limitações existentes para a efetivação dos conselhos como instâncias propositivas no âmbito de políticas públicas, em geral, e, ainda mais, integradas.

Os problemas referentes à capacidade dos conselheiros exercerem influência nos processos decisórios também foram identificados em instâncias colegiadas de sistemas de saúde de outros países, como Itália e Inglaterra, conforme relatado no estudo desenvolvido por SERAPIONI e ROMANÍ (2006). Os autores, que também analisaram o caso brasileiro, apontaram como recomendação que os órgãos de representação intensifiquem as relações com as bases sociais das comunidades e grupos representados, o que também daria conta de melhorar a representatividade dos próprios conselheiros. 
4.2 OS CONSELHOS GESTORES DAS SUPERVISÕES TÉCNICAS DE SAÚDE - SÃO MIGUEL PAULISTA, ERMELINO MATARAZZO E VILA MARIANA

\section{Composição, organização e infra-estrutura}

O Conselho Gestor da Supervisão Técnica de Saúde de São Miguel Paulista existe desde 2001 e foi criado como Conselho de Coordenadoria de Saúde. Segundo a responsável técnica pelo Conselho Gestor de São Miguel Paulista, "o conselho surgiu como uma demanda da população que teve apoio governamental através da lei que estabelece a criação dos conselhos gestores" referência ao Decreto $n^{0} 38.576$ de 5 de novembro de 1999 (PMSP, 1999b) -, primeira vez que aparece na legislação algo sobre Conselhos Gestores de Saúde.

Segundo as informações fornecidas por responsáveis pelo Conselho na Supervisão Técnica de Saúde, para ser membro do Conselho Gestor da Supervisão, o candidato precisa ser membro do conselho gestor de uma Unidade de Saúde da região. Além disso, espera-se que seja uma pessoa com participação ativa na unidade e que entenda o funcionamento dos serviços de saúde. O processo eleitoral acontece primeiro nas Unidades de Saúde, com apoio da Supervisão Técnica de Saúde. Depois, forma-se uma comissão eleitoral que é tripartite ( $50 \%$ de usuários, $25 \%$ de trabalhadores da área e $25 \%$ da administração) e que determina as normas e prazos do processo eleitoral. Em seguida, cada segmento organiza suas eleições, sendo que o número de conselheiros a serem eleitos é definido pelo segmento dos usuários, isto é, se os usuários elegerem doze representantes, então, serão seis vagas para o segmento da administração e seis vagas para o segmento dos 
trabalhadores da área, seguindo a determinação tripartite. Os membros da administração são definidos em reunião, onde se é informado sobre as eleições e abre-se à participação dos interessados. Há pessoas que são convidadas pela Supervisão, geralmente funcionários da própria Supervisão e gerentes de unidades de saúde; os representantes dos hospitais geralmente são os diretores. A organização social que tem parceria com a administração pública indica seu representante.

Segundo a responsável técnica pelo Conselho não há um coordenador do Conselho, ou seja, não existe ninguém na Supervisão Técnica de Saúde que tenha sob sua incumbência o Conselho. Durante a observação das reuniões percebeu-se que quem coordena de fato as reuniões do Conselho é a supervisora, que compõe o segmento da administração e é membro nato do Conselho.

Em relação ao repasse de informações dos conselheiros para os seus representados e para a comunidade em geral, os dois membros da Supervisão entrevistados afirmaram que isso é feito durante as reuniões dos conselhos das unidades e em espaços próprios de cada segmento. Além disso, ressaltaram que a reunião é aberta à participação de quem desejar; o que de fato pôde ser observado, pois muitas pessoas que não eram membros do Conselho participaram das reuniões.

O Conselho Gestor de São Miguel Paulista possui Regimento Interno próprio, que é revisto na primeira reunião após as eleições por todos os conselheiros. Caso não se esgote a revisão do Regimento nesta reunião, é formada uma comissão eqüitativa de conselheiros para dar continuidade ao que faltar e apresentar as propostas ao plenário do Conselho Gestor, onde ele é discutido e 
aprovado.

A versão mais recente do Regimento Interno do Conselho Gestor de São Miguel Paulista data de 4 de maio de 2006, e baseia-se na Lei $\mathrm{n}^{\circ} 13.325$ de 8 de fevereiro de 2002 (PMSP, 2002a) e no Decreto $n^{\circ} 42.005$ de 17 de maio de 2002 (PMSP, 2002b). Porém, esta Lei foi modificada pela de $n^{\circ} 13.716$ de 7 de janeiro de 2004 (PMSP, 2004a), e o Decreto foi revogado pelo de $n^{\circ} 44.658$ de 23 de abril de 2004 (PMSP, 2004b). Ou seja, o Regimento Interno vigente do Conselho Gestor de São Miguel Paulista baseia-se em uma legislação que já sofreu modificações e que se referia ainda aos Conselhos Gestores Distritais de Saúde, quando a legislação mais recente sobre Conselhos Gestores dispõe sobre os conselhos de coordenadorias de saúde que, como citado anteriormente, é a legislação que orienta os Conselhos Gestores de Supervisões Técnicas de Saúde. O Regimento Interno diz que o Conselho Gestor da Supervisão Técnica de Saúde de São Miguel Paulista terá composição quadripartite, com dezesseis membros e respectivos suplentes, sendo $50 \%$ de representantes do segmento dos usuários, $25 \%$ do segmento dos trabalhadores e $25 \%$ repartidos entre o poder público e prestadores de serviços. Mas, o Decreto $n^{0} 44.658$ (PMSP, 2004b) vigente estabelece que 0 Conselho Gestor da Coordenadoria de Saúde (interpreta-se por Conselho Gestor da Supervisão Técnica de Saúde) deve ter 24 membros e respectivos suplentes, com a mesma distribuição entre os segmentos.

No Regimento consta que o Conselho Gestor de São Miguel Paulista é formado pelo Colegiado Pleno e pela Secretaria Geral, que é composta por funcionários, servidores ou empregados públicos indicados pela Supervisão Técnica de Saúde. Cabe a esta 
secretaria o apoio técnico-administrativo ao Conselho Gestor de São Miguel Paulista, fornecendo a pauta e os materiais necessários com antecedência, fazendo a ata, arquivando os materiais do Conselho, entre outras atividades relativas à organização e funcionamento do Conselho. Na prática, a secretaria geral fica a cargo da secretária da Supervisão Técnica de Saúde.

O Regimento Interno do Conselho de São Miguel Paulista dispõe sobre a participação de entidades e movimentos, estabelecendo que estes exercem mandato de dois anos com direito à recondução, mas foi observado que os atuais membros do Conselho não se colocam como representantes de entidades e sim de Conselhos de Unidades de Saúde.

Sobre a participação da Supervisão Técnica de Saúde de São Miguel Paulista no Conselho Gestor, não há nada disposto no Regimento Interno, mas como visto na legislação referida sobre conselhos gestores, o supervisor técnico é membro nato do conselho, integrando a porcentagem do segmento da administração.

As reuniões do Conselho Gestor da Supervisão Técnica de Saúde de São Miguel Paulista ocorrem mensalmente. À época da pesquisa o segmento dos trabalhadores deste Conselho não estava completamente constituído, havendo apenas dois eleitos.

Na primeira reunião observada percebeu-se que os membros do Conselho não receberam a pauta e os materiais da reunião com antecedência e só tiveram acesso a esses ao chegarem para a reunião. Isto se repetiu na segunda reunião observada. Teoricamente, a pauta deve ser definida na reunião anterior, porém a supervisora técnica de saúde indicou os pontos de pauta segundo a ata da reunião anterior, após a leitura desta, ou seja, a 
pauta foi organizada no início da reunião.

O local das reuniões é o Ambulatório Tito Lopes, onde funcionava a Supervisão Técnica de Saúde de São Miguel Paulista (agora alocada na Subprefeitura de São Miguel Paulista). É um local de fácil acesso para os moradores da região; há pontos de ônibus próximos por onde passam diversas linhas de transporte coletivo. As reuniões acontecem na sala de reuniões do ambulatório e as cadeiras ficam dispostas em círculo. O tamanho da sala é adequado e a disposição das cadeiras não dificulta a participação de nenhuma pessoa.

A maioria dos membros manifestou-se durante as reuniões, sobressaindo-se quatro conselheiros do segmento dos usuários e a Supervisora Técnica de Saúde. Não houve a presença de nenhuma entidade e/ou associação nas reuniões. Havia uma convidada, que na verdade seria uma futura representante do segmento da administração por parte dos prestadores de serviços. No entanto, na primeira reunião observada, ainda não havia sido feita a indicação oficial por parte da organização social de saúde. $\mathrm{Na}$ segunda reunião, a indicação já havia sido homologada e a representante da organização social prestadora de serviços passou a contar como membro do segmento da administração.

Os pontos de pauta das reuniões observadas do Conselho Gestor da Supervisão Técnica de Saúde de São Miguel Paulista foram: "Pesquisa da Faculdade de Saúde Pública com o Conselho" (esta a que se refere este estudo), "Falta do segmento dos trabalhadores na composição da nova gestão do Conselho", "Ultrassom" (fila muito grande nas unidades de saúde para fazer este exame), "Falta de médicos", "Mau atendimento em UBS's", "UBS Parque Paulistano e o programa 'AMA' (Assistência Médica 
Ambulatorial)", "Dia D" (projeto de combate à dengue) e "PréConferência Municipal de Saúde". Os pontos que demandaram mais tempo de discussão foram "Falta de médicos" e "Mau atendimento nas UBS's". A reunião começou com 45 minutos de atraso, devido à espera pelo quórum de metade mais um do total de membros do Conselho, segundo o Regimento Interno; e acabou uma hora após o tempo de duração estipulado. A pauta foi cumprida, mas não na ordem que havia sido estabelecida no início da reunião, pois alguns conselheiros do segmento dos usuários incluíram na discussão assuntos que não haviam sido considerados pontos de pauta pela supervisora técnica.

Na outra reunião observada, a pauta, também organizada no início da reunião, incluía: "Pré-Conferência Municipal de Saúde", "Segmento dos trabalhadores no Conselho", "Regulação de vagas" (para exames) e "Mãe Paulistana" (programa da administração pública municipal). A pauta foi cumprida, porém, o último item foi muito pouco discutido, pois durante sua discussão levantou-se outro ponto, já discutido na reunião anterior (AMA). Percebeu-se que a maioria dos conselheiros do segmento dos usuários é contra este programa da Prefeitura de São Paulo e esse tema sempre retorna e os usuários cobram um posicionamento claro da Supervisão Técnica de Saúde.

Em todos os itens da pauta houve discussão entre os membros presentes, porém não houve votação e nem decisão por consenso, percebeu-se que quem, efetivamente, toma as decisões é a supervisora técnica de saúde. Isto ficou perceptível na definição dos pontos de pauta das reuniões, houve temas que os conselheiros do segmento dos usuários queriam discutir e que a supervisora não permitiu pois disse que iria tomar muito tempo; o 
espaço dos informes por vezes é omitido pela supervisora, o que faz com que os conselheiros, em suas falas durante a reunião, coloquem outras questões que gostariam de comunicar ou discutir. Então, na maioria das vezes, os pontos adicionais levantados pelos conselheiros acabam sendo discutidos durante a mesma reunião, alterando a pauta continuamente e criando um certo atrito entre a coordenação do Conselho (principalmente a supervisora) e o segmento dos usuários. Enfatizaram que a comunicação entre os conselheiros e a coordenação do Conselho é ruim, que não tomam conhecimento do que acontece fora das reuniões. Na percepção dos conselheiros a supervisora centraliza todos os encaminhamentos. Como resposta à crítica, a supervisora pediu que cada segmento indicasse um representante para que a coordenação do Conselho pudesse se comunicar mais facilmente e este fazer comunicação aos demais membros. Os conselheiros do segmento dos usuários marcaram uma reunião para discutir essa sugestão e na reunião seguinte indicaram dois membros para atender a solicitação da supervisora.

Outra constatação é que no Conselho de São Miguel Paulista há a participação de pessoas que não são conselheiras, mas que têm interesse em participar nas discussões - foi observado que uma pessoa do Movimento Popular de Saúde da Zona Leste participa regularmente e que se coloca freqüentemente, na maioria das vezes questionando os posicionamentos e encaminhamentos da Supervisão Técnica de Saúde e da administração pública municipal como um todo.

A formação do Conselho Gestor da Supervisão de Saúde de Ermelino Matarazzo também ocorreu no ano de 2001. Primeiramente, houve a formação dos Conselhos Gestores das 
Unidades de Saúde a partir dos Conselhos Populares de Saúde que são organizados pela própria população, através de movimentos sociais locais com ligação ou não a algum movimento de saúde de maior abrangência. Dos conselhos populares são indicados os representantes para o conselho gestor da unidade de saúde e, da unidade de saúde, são indicados os representantes para o conselho gestor da supervisão. Cada unidade tem autonomia para decidir como será feita a eleição, se por voto ou aclamação em assembléia. Geralmente, o processo ocorre com formação de chapa e na maioria dos casos, chapa única. Todo este processo acontece no segmento dos usuários e dos trabalhadores da área: a composição do segmento da administração é determinada por indicação da Supervisão Técnica de Saúde, segundo um critério de rotatividade entre todas as unidades da região. Procura-se, de acordo com as informações dos responsáveis técnicos pelo conselho, sempre ter representação das unidades de saúde com problemas mais complexos, das unidades de especialidades e dos serviços de saúde mental, mesclando os indicados entre as pessoas experientes e as novatas em termos de participação no Conselho.

Em 2004, o processo eleitoral ocorreu normalmente, porém, em 2006, devido à diminuição da participação da população nos Conselhos Populares, não houve processo eleitoral, mantendo-se a mesma composição por mais um ano.

No ano de 2007, ocorreram eleições para uma nova gestão até 2009. Para essas eleições algumas unidades não enviaram representantes, pois não houve formação de conselhos gestores em todas as Unidades de Saúde; fato este, segundo a avaliação da responsável técnica pelo Conselho Gestor da Supervisão, ligado ao histórico de participação popular, pois há instituições e associações 
atuantes na área da saúde que não se vinculam aos conselhos de saúde Das Unidades. Essas Unidades encaminham suas demandas através das caixas de sugestões que existem nas unidades, das ouvidorias e das reuniões que acontecem na comunidade com a Supervisão Técnica de Saúde.

Quanto à coordenação do Conselho, a Supervisão Técnica de Saúde tem assumido este papel, mas estava prevista a discussão desse processo na revisão do Regimento Interno do Conselho.

O repasse de informações dos membros do Conselho aos representados e à comunidade tem encontrado dificuldades, uma vez que a atuação dos Conselhos Populares de Saúde está diminuída. Segundo a supervisora técnica responsável pelo Conselho Gestor de Ermelino Matarazzo, as informações do Conselho Gestor da Supervisão com certeza chegam aos conselhos gestores das unidades representadas. Estes, por sua vez, devem procurar usar outros espaços na comunidade para repassarem essas informações. Alguns representantes fazem o repasse por meio de associações de moradores, grupos eclesiais de base e outros grupos específicos.

O Conselho Gestor da Supervisão de Ermelino Matarazzo tem Regimento Interno próprio, elaborado em gestões anteriores, mas que pode ser modificado a cada nova gestão, baseado nas demandas da região e no regimento do Conselho Municipal de Saúde. Este mandato de 2007 a 2009 reviu e modificou o regimento anterior, colocando em vigor o novo Regimento Interno em 25 de setembro de 2007.

Neste novo Regimento Interno observa-se que a composição do Conselho Gestor da Supervisão de Ermelino Matarazzo é de 24 membros titulares e respectivos suplentes, totalizando 48 
membros. Uma alteração ocorrida refere-se à variação dos segmentos presentes no Conselho; no Decreto n ${ }^{\circ} 44.658$ de 2004 (PMSP, 2004b) consta que a composição dos Conselhos Gestores de Supervisões de Saúde deve ser quadripartite, com $50 \%$ de membros do segmento dos usuários, $25 \%$ do segmento dos trabalhadores da área e $25 \%$ do segmento da administração divididos entre poder público e prestadores de serviços. No Regimento Interno em vigor consta que a composição do Conselho Gestor é tripartite, com a mesma composição anterior, mas com a diferença de interpretação sobre o segmento da administração: passa a não mais haver a distinção entre administração pública e privada como duas partes do mesmo segmento.

Não há referência explícita no Regimento Interno quanto à participação de representantes de entidades e movimentos no Conselho Gestor de Ermelino Matarazzo mas, de acordo com informações obtidas no contato com o Conselho, a participação pode ser individualmente ou por entidade. Para se candidatar, a pessoa deve estar ligada a algum tipo de movimento ou representação local (sociedade de amigos de bairro, movimento popular de saúde ou associação de moradores, por exemplo) e necessariamente deve estar no conselho gestor de uma Unidade de Saúde da região.

Em relação à participação da Supervisão Técnica de Saúde no Conselho Gestor, está estabelecido que o supervisor técnico de saúde é membro nato do Conselho, tendo direito à voz e apenas ao voto de qualidade, que deve ser exercido em caso de empate.

As reuniões ocorrem mensalmente na Supervisão de Saúde de Ermelino Matarazzo. A coordenação e secretaria das reuniões podem ser definidas a cada mês, ao final de cada reunião, podendo 
ficar sob responsabilidade de um dos três segmentos. Cabe ao coordenador, a preparação dos temas da pauta, com a disponibilização do material necessário com antecedência de, no mínimo, uma semana antes das reuniões. De acordo com as observações das reuniões os conselheiros parecem não receber a pauta com antecedência, como estabelecido no regimento interno.

O local das reuniões é a sede da Supervisão Técnica de Saúde de Ermelino Matarazzo. Não foi possível saber se houve discussão com os conselheiros sobre a escolha do local, mas a secretária da Supervisão afirmou que esta é bem localizada para os conselheiros, pois eles residem na mesma região. A reunião acontece no anfiteatro, com as cadeiras dispostas em círculo, formando-se por vezes um semicírculo no meio devido ao tamanho da sala não favorecer a disposição de todas as cadeiras em um único grande círculo.

Percebeu-se que os conselheiros demonstravam um grande respeito pela supervisora técnica de saúde que se colocou bastante durante a reunião. Alguns conselheiros não se manifestaram nenhuma vez, mas a maioria se manifestou. Em alguns momentos, a supervisora não deu muita abertura para os conselheiros participarem, sempre manifestando primeiro a sua opinião e enfatizando como isso ou aquilo seria bom para o Conselho.

Quanto à presença de convidados, na primeira reunião observada não houve, mas para a segunda haviam sido convidadas duas pessoas, especificamente para a discussão dos itens Pacto da Saúde e Organizações Sociais em Saúde. O que ocorreu foi que no momento em que esses pontos foram inclusos, a Supervisão de Saúde dispôs-se a convidar uma pessoa da administração pública para comparecer à reunião e apresentá-los, prestando os 
esclarecimentos necessários. Porém, um conselheiro do segmento dos usuários reivindicou que deveriam ser mostrados os dois lados dessa discussão, então se propôs a convidar uma pessoa de um movimento popular de saúde. Entretanto, no dia da reunião, apenas compareceu o convidado da Supervisão, pois o convidado do conselheiro do segmento dos usuários teve dificuldades para comparecer no horário proposto para a reunião.

Os temas que constaram das reuniões observadas do Conselho Gestor da Supervisão Técnica de Saúde de Ermelino Matarazzo foram: "Eleição do Conselho" (confirmação da indicação dos nomes feita pelos conselhos gestores das unidades), "Representação no Interconselhos" (instância de articulação entre todos os conselhos gestores de supervisões de Saúde), "Pesquisa da Faculdade de Saúde Pública" (esta a que se refere este estudo), "Pré-conferência Municipal de Saúde", "Indicadores do painel de monitoramento" e "Saúde Mental". Dentre os temas, o que demandou mais tempo foi a Pré-Conferência de Saúde. Em outra reunião a pauta constou de "Pacto da Saúde", "Organizações Sociais em Saúde", "Pré-Conferência Municipal de Saúde" e "Indicadores do painel de monitoramento".

Em todos os pontos de pauta houve ampla discussão e as votações ocorreram mais para legitimar o processo, pois a maioria dos tópicos foi decidida por consenso. Nas reuniões observadas, os suplentes também votaram e, ao se indagar isto à supervisora técnica, a justificativa apresentada foi que ainda não tinham um Regimento Interno que regularizasse oficialmente o processo de votação. Ressaltou que tanto os titulares como os suplentes e inclusive pessoas que não são membros do Conselho Gestor da Supervisão costumavam participar das reuniões, mas que com o 
novo Regimento passariam a votar só os titulares.

Segundo a responsável técnica pelo Conselho, a formação do Conselho Gestor de Vila Mariana deu-se no período pós PAS (Plano de Assistência à Saúde), em torno dos anos de 2000-2002, quando o SUS ainda não estava implementado na cidade de São Paulo e cada coordenadoria de saúde estava formando seu conselho gestor. Na Vila Mariana, o coordenador de saúde convocou uma reunião com diversos movimentos e associações da área da saúde para explicar sobre as instâncias de controle social e sobre a legislação em saúde. A partir disso, foi feito, em conjunto, um trabalho de divulgação dos conselhos gestores, até ser possível realizar um processo eleitoral, que teve inclusive um ato solene de posse, o qual é referido até hoje por muitos conselheiros.

Essa informante destacou que existem discordâncias quanto ao processo de junção das coordenadorias de Vila Mariana e Jabaquara, que ocorreu devido à criação das Supervisões Técnicas de Saúde, porque essas duas regiões são muito diferentes em relação à conjuntura social, ao nível sócio-econômico e à qualidade de vida da população.

De acordo com as informações obtidas, as eleições do Conselho Gestor de Vila Mariana são amplamente divulgadas nos painéis das Unidades de Saúde, sendo respeitado o prazo de inscrição para os candidatos. O segmento da administração é composto pelo Supervisor Técnico de Saúde, que é membro nato, e, geralmente por mais uma pessoa da Supervisão que tenha mais ligação com o Conselho.

A participação no Conselho é por meio de representação pessoal, e não por entidade ou Unidade de Saúde, podendo haver mais de um representante da mesma unidade. Não há critério para 
se candidatar ao Conselho, porém, em uma determinada época, algumas pessoas diziam que o critério era ser morador da região. Entretanto, ao se buscar o Conselho Municipal de Saúde para esclarecer essa questão, encontrou-se que o que de fato dita a possibilidade de participar nos conselhos gestores é o uso do serviço de saúde local, ainda que a pessoa more em outra região. De qualquer forma, percebeu-se que todos os membros entrevistados compunham também o conselho gestor de alguma Unidade de Saúde da região.

Quanto à coordenação do Conselho, geralmente quem desempenha este papel é algum representante da Supervisão de Saúde, mas atualmente está acontecendo um rodízio entre os conselheiros: ao final de cada reunião escolhe-se o coordenador da próxima reunião.

Segundo a supervisora, não existe uma divulgação ampla de informações dos conselheiros para seus representados e para a comunidade em geral e avalia que, atualmente, a população não tem se interessado muito pelas atividades dos conselhos.

O Conselho Gestor de Vila Mariana também possui um Regimento Interno que, segundo a supervisora técnica de saúde, foi construído na primeira gestão, quando ainda se denominava Conselho de Coordenadoria de Saúde. Este Regimento data de 16 de setembro de 2004 e baseia-se na Lei $n^{\circ} 13.325$ de 8 de fevereiro de 2002 (PMSP, 2002a), considerando as alterações dadas pela Lei $n^{\circ} 13.716$ de 7 de janeiro de 2004 (PMSP, 2004a). Segundo este Regimento, a composição do Conselho Gestor de Vila Mariana é quadripartite, com 24 membros e respectivos suplentes, sendo $50 \%$ de representantes do segmento dos usuários, $25 \%$ do segmento dos trabalhadores e $25 \%$ do segmento da administração, 
repartidos entre poder público e prestadores de serviços.

O Conselho organiza-se em plenário (todos os conselheiros reunidos), comissão executiva e secretaria geral. A comissão executiva tem por atribuição acompanhar e encaminhar as medidas decididas no Conselho; é composta por dois representantes do segmento dos usuários, um do segmento dos trabalhadores e um do segmento da administração, que devem ser indicados entre seus pares e eleitos pelo plenário do Conselho por maioria simples; contará com um coordenador e um respectivo suplente, que serão eleitos dentre seus membros e ratificados pelo plenário. Na prática do Conselho Gestor de Vila Mariana, a comissão executiva é quem elabora as pautas das reuniões e para isso deve se reunir uma semana antes da reunião do Conselho. Já a secretaria geral é um órgão vinculado à Supervisão Técnica de Saúde de Vila Mariana, que tem por função fornecer todo o apoio técnico-administrativo necessário para o funcionamento do Conselho. É a secretaria geral que prepara as reuniões, os materiais necessários com antecedência e faz as atas, entre outras atividades organizativas.

Sobre a participação da Supervisão Técnica de Saúde no Conselho Gestor, o supervisor técnico é membro e presidente nato do Conselho, possuindo voto de qualidade em caso de empate. A ele é atribuída a função de coordenar as reuniões; na sua ausência fica com esta função o coordenador da comissão executiva. $\mathrm{Na}$ ausência de ambos a coordenação da reunião fica a cargo de um membro indicado pelo plenário.

Ressalta-se que o Regimento Interno do Conselho Gestor de Vila Mariana, assim como o de São Miguel Paulista, refere-se à participação de entidades e movimentos no Conselho, dispondo que estes têm mandato de dois anos com direito à recondução, embora 
tenha sido relatado pela supervisora técnica de saúde que a participação não se dá por entidade.

As reuniões ocorrem mensalmente na sala de reunião do Ambulatório de Especialidades CECI - Dr. Alexandre Kalil Yasbeck.

Durante a reunião observada notou-se que não havia pauta estruturada para a reunião e os materiais referentes a um dos informes da Supervisão de Saúde não foram disponibilizados com antecedência. A reunião começou com 40 minutos de atraso.

Segundo a responsável técnica pelo Conselho, o local é de fácil acesso para os conselheiros. As cadeiras estavam dispostas em círculo ao redor de uma mesa; havia cerca de quinze pessoas, o que fazia com que algumas tivessem dificuldade de verem as outras. Os membros do segmento da administração sentaram-se uns ao lado dos outros.

No início da reunião foi feita uma rodada de apresentação. Em seguida fez-se a leitura da ata da reunião anterior e perguntouse se alguém tinha algum destaque. Então se passaram aos informes. Alguns pontos de pauta corresponderam mais a informes, tais como a proposta da Coordenadoria Regional de Saúde Sudeste para a realização das reuniões dos conselhos gestores de maneira uniforme. A proposta foi lida e alguns conselheiros questionaram alguns pontos, dentre eles, o ponto que dispunha sobre a coordenação das reuniões dos Conselhos. Um conselheiro do segmento dos usuários ressaltou que não possuem um coordenador eleito, uma vez que o presidente nato do Conselho, pelo Regimento geral dos conselhos gestores, é o supervisor de saúde e na ausência dele deve ser eleito um coordenador pela Comissão Executiva do Conselho. Em reunião anterior, haviam decidido que não elegeriam um coordenador 
previamente e o fariam quando fosse necessário.

Esse mesmo conselheiro, após esse ponto de discussão, sugeriu que houvesse inscrição para falar e que fosse escolhido um coordenador para a reunião. Foi escolhida a responsável técnica pelo Conselho que era quem já estava desempenhando este papel; para a reunião seguinte, o conselheiro que deu a sugestão se voluntariou para a tarefa e todos concordaram. Nesta reunião observada, a Supervisora Técnica de Saúde estava presente, porém, pôde-se perceber que ela não costuma coordenar as reuniões e quem desempenha este papel é a responsável técnica pelo Conselho da Supervisão Técnica de Saúde de Vila Mariana. Notou-se, então, que a prática adotada por este Conselho não segue literalmente o que diz seu Regimento Interno, quanto à coordenação das reuniões, mas sim procura dividir a coordenação das reuniões entre os conselheiros interessados e disponíveis, não centralizando a tarefa nos membros da Supervisão Técnica ou da Comissão Executiva.

Após os informes, um conselheiro do segmento dos usuários propôs um ponto de pauta: discutir as políticas públicas de saúde para hipertensão e diabetes, considerados os maiores problemas de saúde da região de Vila Mariana. Outro conselheiro do segmento dos usuários disse também ter outros pontos para a pauta. Mas, mesmo a pauta não tendo sido estabelecida, entrou-se na discussão sugerida pelo primeiro conselheiro (políticas públicas para hipertensão e diabetes). Este ponto tomou grande parte da reunião, até o momento em que outro conselheiro exaltou-se, alegando que a reunião tinha ficado em um ponto de pauta só e disse que se não fosse ouvido recorreria à Secretaria de Saúde e ao Ministério Público. Disse ainda que também tinha pontos de 
pauta e da maneira como havia sido conduzida a reunião não haveria tempo para discussão. Reclamou que os assuntos são discutidos, mas as respostas nunca retornam oficialmente. Propôs, então, que todos os encaminhamentos e respostas a ofícios e similares fossem feitos por escrito. Falou sobre o critério de presença nas reuniões do Conselho, enfatizou que fosse cumprido o que diz no Regimento - mais de três faltas sem justificativa o caso é levado ao plenário que decidirá sobre a exclusão ou não do conselho do conselheiro ausente. Pediu também que os conselheiros tenham acesso a um telefone para que pudessem telefonar para os outros, convocando-os para as reuniões. A presidente do Conselho (Supervisora Técnica de Saúde) tentou esclarecer todos os pontos levantados e ficou estabelecido que os conselheiros poderiam utilizar um telefone do ambulatório onde acontecem as reuniões.

Neste momento iniciou-se involuntariamente o fim da reunião, pois o teto estipulado para o término da reunião ( $11 \mathrm{~h} 00$ ) já havia sido ultrapassado. Algumas pessoas começaram a se levantar para tomarem café e iniciaram-se muitas conversas paralelas. Após o término oficial da reunião - quando os conselheiros assinaram a ata - alguns conselheiros ainda permaneceram certo tempo discutindo problemas específicos de uma Unidade de Saúde.

Não houve a presença de convidados e não foi possível perceber a presença de alguma associação e/ou entidade representada no Conselho Gestor de Vila Mariana. Não ocorreu processo de votação, pois o que foi colocado para consulta foi aprovado por consenso.

Comparando-se a composição do Conselho com seu 
Regimento Interno, percebeu-se que o segmento dos usuários dispõe de $50 \%$ dos membros, como estabelecido. Porém, o segmento dos trabalhadores acaba por ter uma representação maior do que a esperada, com 33,3\% ao invés de $25 \%$, e a administração fica com uma representação menor do que a esperada, com $16,7 \%$ ao invés de $25 \%$. Isto acontece porque somente o segmento dos trabalhadores ocupou todas as vagas de titulares a que tinha direito - o segmento dos usuários tem doze vagas oficialmente, mas elegeu apenas dez representantes, sendo que um deles deixou o Conselho pouco antes do período em que esta pesquisa foi realizada; o segmento da administração tem seis vagas, mas indicou apenas três representantes, sendo que um deles diz não ter direito a voto, alegando ser um convidado da Supervisão a sempre participar das reuniões. Entretanto, na listagem dos conselheiros, ele representa a instituição que é parceira do poder público na administração de alguns dos serviços de saúde da Subprefeitura de Vila Mariana/Jabaquara, logo, tendo direito a voto como qualquer outro membro do segmento. Os outros dois membros são a Supervisora Técnica de Saúde e a responsável técnica pelo Conselho.

O acompanhamento das reuniões corroborou o depoimento da responsável técnica pelo conselho de Vila Mariana de que há dois grupos de usuários: um é composto pelos conselheiros de atuação mais pontual, que querem tomar conhecimento das políticas públicas de saúde existentes, procuram explicações sobre o que já existe; o outro grupo é composto por conselheiros que procuram saber como funcionam todos os processos, reivindicam melhor estrutura técnica para sua atuação como conselheiros (exigindo, por exemplo, acesso a um telefone para a convocação das reuniões, um carro para realizarem visitas às Unidades de 
Saúde, uma sala especialmente destinada para o Conselho Gestor da Supervisão Técnica de Saúde). Em conseqüência desta atuação mais enfática, de cobrança intensa sobre a Supervisão Técnica de Saúde, a relação com o segmento da administração torna-se mais conflituosa; entretanto, avalia a responsável técnica pelo Conselho, este é o grupo que mais se aproxima do que ela entende ser um conselho gestor e que, de fato, quer exercer o trabalho de conselheiro de saúde.

É interessante fazer algumas observações sobre a posição da profissional da Supervisão Técnica de Saúde que expressa valorizar - processo de participação social em saúde, mas, a partir da perspectiva do que ela considera ser mais adequado e pertinente em termos da prática dos conselheiros. E também há as questões relativas às condições de infra-estrutura para o cumprimento das atribuições dos conselheiros, ou seja, as atividades são consideradas importantes no discurso e é reconhecida a necessidade de apoio para sua realização, mas é preciso ocorrer cobrança para que sejam viabilizadas as condições básicas.

Outra questão que apareceu mais explicitamente nos Conselhos Gestores de São Miguel Paulista e Ermelino Matarazzo tem a ver com a forma dos gestores lidarem com as instâncias participativas institucionalizadas e isso transparece nas dinâmicas das reuniões. Os conselhos existem por lei, mas os gestores podem estar mais ou menos comprometidos com sua valorização para o intercâmbio, o aprendizado e a construção conjunta de um espaço democrático. Se o comprometimento é pequeno e não se acredita que a formação e a capacitação são frutos de processos contínuos, há uma tendência a resolver e encaminhar isoladamente, sem respeitar e considerar o tempo e a vivência do outro. 
A partir da descrição dos Conselhos Gestores das três Supervisões Técnicas de Saúde nota-se que existem limitações relativas às suas condições de funcionamento - organização e desenvolvimento das reuniões, definição das pautas e infraestrutura - para o adequado cumprimento das atribuições esperadas.

$\mathrm{Na}$ organização e desenvolvimento das reuniões, assim como na definição das pautas há, claramente, papel preponderante do segmento da administração, o que não deve ser confundido com a orientação de que cabe ao poder público disponibilizar as condições necessárias de infra-estrutura para o funcionamento dos conselhos gestores nos seus diferentes níveis. Esse tipo de situação tem sido observada, de forma recorrente, em pesquisas realizadas junto a conselhos de saúde municipais ou estaduais e pode-se estender tais problemáticas para os conselhos locais (ESCOREL e DELGADO, 2008; DELGADO e ESCOREL, 2008; MOREIRA e col., 2008). Se $20 \%$ dos Conselhos Municipais de Saúde dos municípios com mais de cem mil habitantes e $40 \%$ dos Conselhos dos municípios com menos de cem mil habitantes, não tem acesso a linha telefônica, é de se supor que as porcentagens sejam maiores no caso dos conselhos locais, que é o que acontece no Conselho da Supervisão Técnica de Saúde de Vila Mariana e, na maioria dos casos, poucos conselheiros devem se manifestar de forma tão veemente na cobrança desse direito. O mesmo deve ocorrer quanto ao acesso a computador e internet, considerando que as porcentagens já são mais baixas do que o acesso à linha telefônica nos Conselhos Municipais, segundo a pesquisa Monitoramento e Apoio à Gestão Participativa do SUS (MOREIRA, 2008).

Conforme abordado em vários estudos (WENDHAUSEN e 
CARDOSO, 2007; ABERS e KECK, 2008), os aspectos relativos à definição da agenda temática e das pautas das reuniões não devem ser desprezados nas análises, pois se pode considerar que essa é a primeira etapa do processo decisório: sobre o que deliberar. A inclusão ou não de determinados assuntos depende da forma de participação e atuação dos grupos envolvidos, mediados por grupos de pressão, opinião pública, mídia e partidos políticos. Em geral, as pautas são elaboradas previamente pelos responsáveis técnicos dos conselhos, ligados ao poder público municipal, com a justificativa de que seu papel é viabilizar e garantir o funcionamento dos conselhos. O problema está na pouca permeabilidade do processo, no qual acabam predominando as indicações do segmento da administração.

Também transparecem nas observações, as relações assimétricas entre os conselheiros usuários e o segmento da administração, mesmo que de forma não explícita; como conseqüência, há o uso de determinados discursos que pretendem encerrar as possibilidades de interlocução (WENDHAUSEN e CAPONI, 2002), conforme relatado pelos conselheiros de São Miguel Paulista e Ermelino Matarazzo: dificuldades de comunicação entre conselheiros e coordenação, centralização dos encaminhamentos, não espaço para a fala dos conselheiros usuários, concentração de falas dos representantes da administração.

Essas relações assimétricas também ajudam a compor o quadro de disputa pela hegemonia nos espaços de participação que, como já indicado anteriormente, não são arenas políticas abertas, em que todos os participantes contam com as mesmas condições de atuação. 
Para o segmento dos usuários foi perguntado sobre o critério para determinar a titularidade e a suplência dos conselheiros deste segmento. No Conselho Gestor de São Miguel Paulista, dois disseram que havia sido por votação; um disse que foi por consenso em reunião do conselho gestor da Unidade de Saúde e outro disse que os membros foram escolhidos por aclamação em uma reunião.

Dos membros do segmento dos usuários do Conselho Gestor da Supervisão de Ermelino Matarazzo, que responderam à pergunta sobre o critério que determinou a titularidade e a suplência, houve respostas diferentes para esta questão: dois membros disseram que os titulares são os candidatos que forem mais votados e, em seqüência, vêm os suplentes; outros dois disseram que era por consenso em reunião entre os eleitos; outros dois disseram ser por indicação; e um dos membros não soube responder.

Esta diferença nas respostas confirma que o processo de eleição do segmento dos usuários deu-se segundo critérios diferentes, em cada Unidade de Saúde de onde vieram as indicações para a composição dos Conselhos Gestores das Supervisões Técnicas de Saúde de São Miguel Paulista e Ermelino Matarazzo.

No Conselho Gestor da Supervisão Técnica de Saúde de Vila Mariana, três disseram que geralmente é por votação, mas que nesta gestão não houve candidatos suficientes para preencher todas as vagas; e um membro não soube responder, justamente por este motivo.

Em pesquisa desenvolvida junto às 31 Subprefeituras (COELHO, 2007), em 2004 e 2005, verificou-se que em 29 delas os 
membros para comporem o segmento dos usuários dos Conselhos de Saúde das Supervisões Técnicas foram recrutados junto às Unidades de Saúde da região de abrangência. De acordo com a autora, esse procedimento tem sido utilizado há muitos anos pelo Movimento Popular de Saúde que tem forte presença na região leste desde a década de 1970.

Pode-se supor que o uso desse critério de pertencer ao Conselho Gestor de uma Unidade de Saúde da região para poder ser candidato ao Conselho Gestor da Supervisão Técnica de Saúde, apesar de não estar na legislação dos conselhos gestores, corresponde à manutenção de critério estabelecido por militantes da área da saúde que participaram do processo de criação e implantação dos conselhos gestores com o intuito de garantir que os representantes do segmento dos usuários tivessem uma base social, ou seja, que estivessem ligados a alguma organização local, de forma a ser possível fazer o repasse do que acontece dentro do Conselho de Saúde, debatendo as questões e retornando para o Conselho com os resultados da discussão feita com um coletivo de pessoas.

A apresentação dos procedimentos encontrados para a formação dos três Conselhos Gestores Locais estudados corrobora os elementos destacados por COELHO e VERÍSSIMO (2004) e COELHO (2007) na breve descrição que fizeram dos processos eleitorais ocorridos em 2001 e 2003 para a composição dos, então, Conselhos das Coordenadorias de Saúde das Subprefeituras, ou seja, na prática, tanto há diversos critérios com relação a quem é elegível e necessidade ou não de vinculação com alguma entidade ou associação, quanto há diferentes formas de indicação para compor o Conselho. Além disso, também transparece que a forma 
de empenho e mobilização das Supervisões Técnicas de Saúde no processo de definição dos representantes dos usuários é diferenciada e, em muito, dependente do comprometimento dos gestores públicos com o projeto de participação e controle social, o que faz com que se busque ou não ampliar e incluir mais movimentos e organizações ou se restringir àquelas já conhecidas no circuito da administração pública.

Por outro lado, pelos dados encontrados junto aos Conselhos Gestores das Supervisões Técnicas de Saúde de São Miguel Paulista, Ermelino Matarazzo e Vila Mariana, há indícios de certo enfraquecimento ou desmobilização da participação social no nível local. Tal situação pode ser explicada pelos elementos que caracterizam a participação em São Paulo, considerando estudos já realizados e referidos por AVRITZER, RECAMÁN e VENTURI (2004) que apontaram como principal característica da participação em São Paulo seu aspecto de "sanfona" que se expande e se contrai de acordo com as ações do poder público, ou seja, em decorrência das políticas participativas definidas pelo Estado e dirigidas às associações civis. Na medida em que as reivindicações dos movimentos sociais e de suas organizações são atendidas - por meio de políticas públicas e maior investimento de recursos públicos em áreas menos privilegiadas e mais pobres da cidade - e institucionalizadas - pelo crescimento de espaços e fóruns participativos e estabelecimento de canais de comunicação com o poder público - há um crescimento significativo do número de pessoas e entidades que se envolvem formalmente nos processos participativos, como é possível observar nos períodos mais recentes de gestões municipais mais democráticas e populares e de criação e institucionalização dos conselhos gestores no município (TATAGIBA, 2002; 2004). Nos períodos em que o Estado é mais 
reativo aos movimentos e organizações sociais há uma contração da "sanfona": nesses momentos os atores de adesão mais recente ou que não pertencem ao núcleo participativo mais tradicional paulistano se retiram do cenário.

Os mesmos autores (AVRITZER, RECAMÁN e VENTURI, 2004) indicam que o núcleo participativo da cidade de São Paulo é composto pelo associativismo religioso e popular, vinculados à religião católica e, mais recentemente, religião evangélica e aos movimentos de saúde, de moradia e associativismo comunitário.

A análise apresentada é compatível com a situação do período deste estudo, considerando-se as características das gestões municipais (de continuidade administrativa, na prática) menos permeável à participação social e mais resistente a estabelecer e respeitar espaços mais horizontais de deliberação. Exemplo dessa relação mais conflituosa pôde ser constatado pelos problemas enfrentados para a homologação do resultado da eleição para o mandato 2008-2009 do Conselho Municipal de Saúde de São Paulo.

\section{Perfil sócio-demográfico dos conselheiros}

Houve uma predominância do sexo feminino $(71,4 \%)$ entre os entrevistados do Conselho Gestor da Supervisão Técnica de Saúde de São Miguel Paulista. A faixa etária mais freqüente foi a de 45 a 60 anos ou mais $(85,7 \%)$. 
Figura 21 - Perfil sócio-demográfico dos conselheiros entrevistados do Conselho Gestor da Supervisão Técnica de Saúde de São Miguel Paulista, segundo segmento, São Paulo, 2006 e 2007.

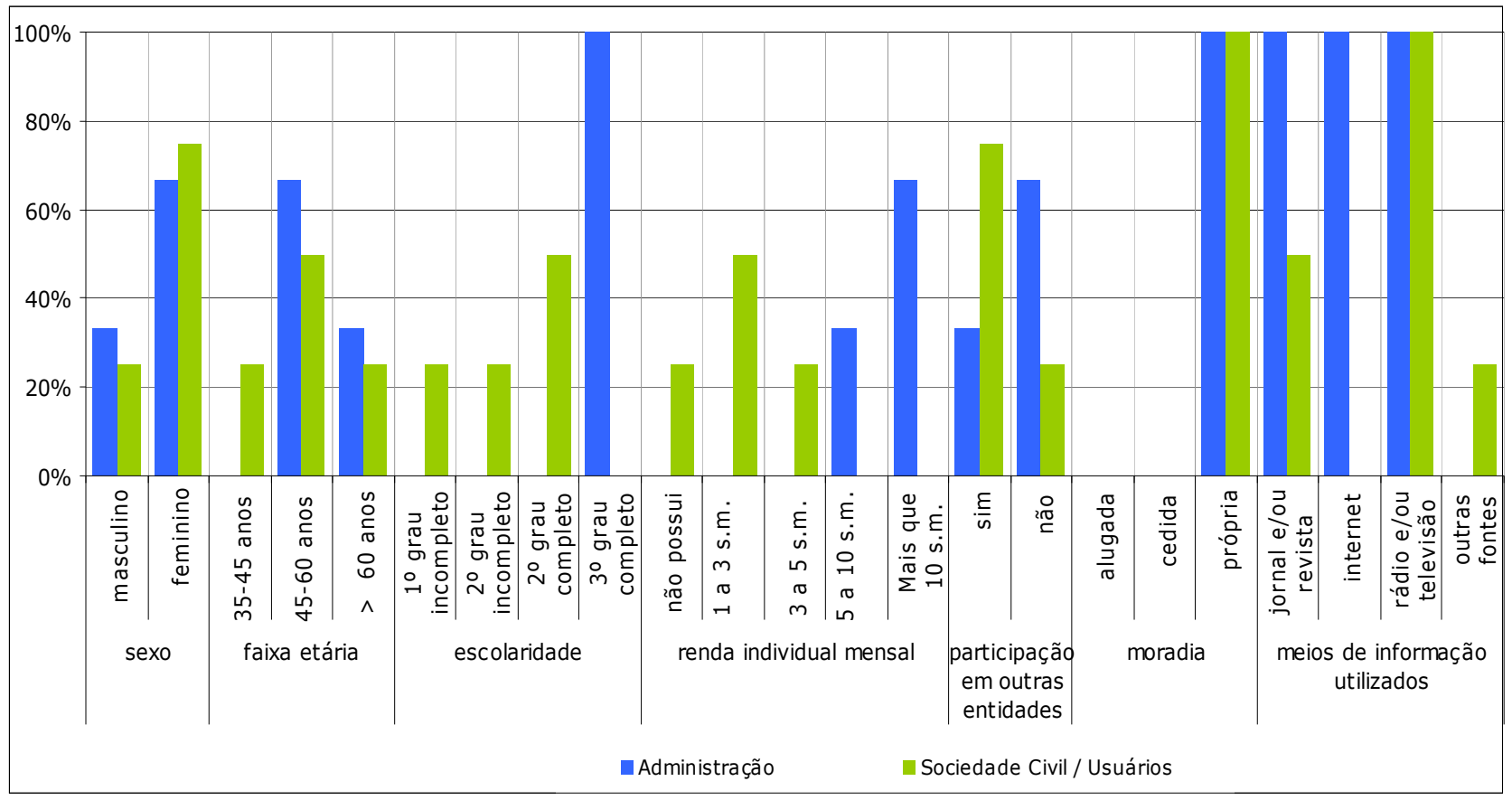

Em relação à escolaridade dos conselheiros percebeu-se que a maioria possui, no mínimo, o $2^{\circ}$ grau completo, sendo que do total, $42,9 \%$ possui $\circ 3^{\circ}$ grau completo: dos sete conselheiros entrevistados, os três membros da administração possuem o $3^{\circ}$ grau completo, no segmento dos usuários o nível de escolaridade mais alto foi o $2^{\circ}$ grau completo (50\%).

Ao se observar a renda dos conselheiros entrevistados encontrou-se um contraste entre os membros da administração e dos usuários. Todos os membros do segmento da administração ficaram na faixa de cinco a dez salários mínimos ou mais, enquanto $75 \%$ dos membros do segmento dos usuários tem até cinco salários mínimos, e os $25 \%$ restantes não possuem renda própria, vivendo da renda do cônjuge. Observou-se que $100 \%$ dos conselheiros entrevistados possuíam moradia própria. 
Conforme esperado, todos os membros do segmento da administração são servidores públicos, ao contrário do segmento dos usuários, onde os que exercem alguma atividade remunerada não têm ligação com o setor público.

Sobre os meios de informação utilizados, todos os membros entrevistados afirmaram utilizar rádio e/ou televisão e uma grande porcentagem afirmou fazer uso de jornal e/ou revista e internet. Destaca-se, entretanto, que o uso da internet foi citado apenas pelos membros do segmento da administração (100\%); o uso de jornal e/ou revista foi citado por metade dos membros do segmento dos usuários, enquanto que no segmento da administração foi citado por $100 \%$. Como outras fontes foram citadas palestras. Ao serem questionados se esses meios de informação eram satisfatórios, mais de $60 \%$ dos membros entrevistados disse que não, alegando que as fontes eram incompletas ou tendenciosas. Dentre esses membros, a maioria (75\%) pertencia ao segmento dos usuários. 
Figura 22 - Perfil sócio-demográfico dos conselheiros entrevistados do Conselho Gestor da Supervisão Técnica de Saúde de Ermelino Matarazzo, segundo segmento, São Paulo, 2006 e 2007.

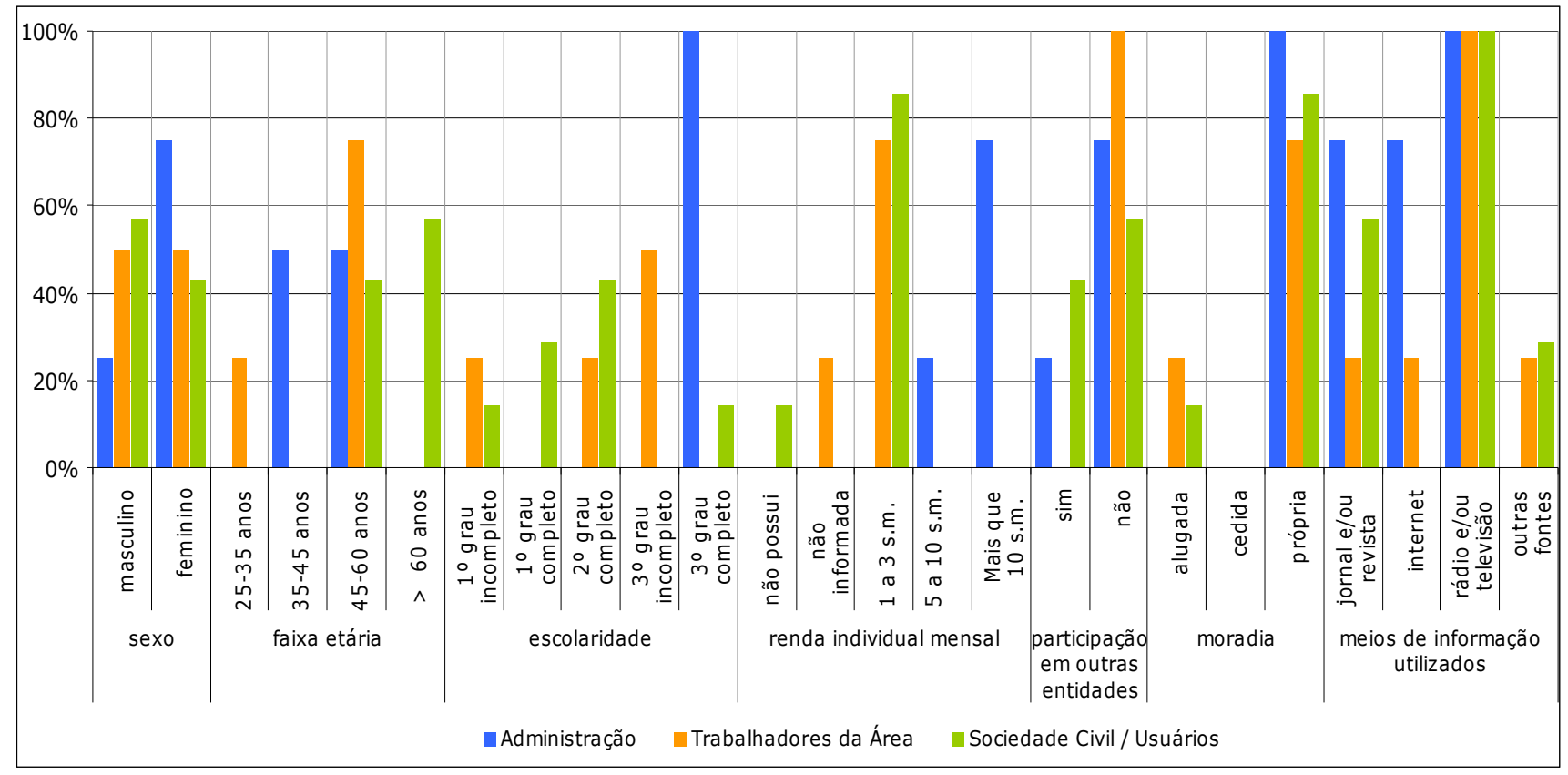

Os membros entrevistados do Conselho Gestor de Ermelino Matarazzo encontram-se compreendidos entre as faixas etárias de 25 a 60 anos ou mais, sendo a maioria ( $80 \%)$, nas faixas de 45 a 60 anos ou mais.

Em relação à escolaridade dos conselheiros, os níveis encontrados foram bem diversos, desde o $1^{\circ} \mathrm{grau}$ incompleto até $\mathrm{o}$ $3^{\circ}$ grau completo, com as maiores freqüências nos níveis do $2^{\circ}$ e $3^{\circ}$ graus completos: $26,7 \%$ e $33,3 \%$, respectivamente. Ressalta-se, porém, que no segmento da administração, $100 \%$ dos membros entrevistados possuem $3^{\circ}$ grau completo, enquanto no segmento dos trabalhadores e dos usuários a dispersão entre os níveis é maior. No segmento dos trabalhadores observa-se que $50 \%$ dos membros entrevistados apresentam $3^{\circ} \mathrm{grau}$ incompleto e os outros $50 \%$ estão divididos entre $1^{\circ} \mathrm{grau}$ incompleto $(25 \%)$ e $2^{\circ} \mathrm{grau}$ 
completo (25\%). Já no segmento dos usuários, a dispersão é mais acentuada, com as maiores freqüências nos níveis do $1^{\circ}$ e $2^{\circ} \mathrm{grau}$ completos (28,6\% e 42,9\%, respectivamente), mas aparecendo também o $1^{\circ}$ grau incompleto $(14,3 \%)$ e o $3^{\circ}$ grau completo $(14,3 \%)$, ou seja, uma dispersão que vai de um extremo ao outro.

Ao se analisar a renda individual dos conselheiros, percebeuse um recorte imediato: o segmento da administração apresentou renda bem maior do que o segmento dos trabalhadores e usuários. Os membros entrevistados da administração encontraram-se na faixa de renda de cinco a dez ou mais de dez salários mínimos, enquanto os membros dos outros dois segmentos estavam na faixa de menos de três salários mínimos, sendo que um dos membros dos usuários declarou não possuir renda individual. Notou-se que a maior parte dos conselheiros entrevistados $(86,7 \%)$ possui moradia própria.

Foi encontrado que a maioria dos conselheiros entrevistados dos segmentos da administração (75\%) e dos trabalhadores da área $(75 \%)$ trabalha no setor público. Já no segmento dos usuários, a maioria $(57,1 \%)$ não exerce atividade remunerada, obtendo a renda através de aposentadoria, pensão ou trabalho em cooperativa. Entre os que exercem atividade remunerada a maior parte não apresenta ligação com o setor público.

Sobre os meios de informação utilizados, todos os entrevistados indicaram o uso de rádio e/ou televisão, e 53,3\% o uso de jornal e/ou revista. Internet e outras fontes foram citadas em menor proporção; destaca-se que o uso da internet não foi citado por nenhum membro do segmento dos usuários. Dentre as outras fontes citadas apareceram livros, participação na comunidade e conversa com outras pessoas. Ao serem 
questionados se essas fontes de informação eram satisfatórias, mais de $70 \%$ dos entrevistados afirmaram que sim. Os que disseram não serem satisfatórias alegaram que as fontes são incompletas ou tendenciosas. Destaca-se que $75 \%$ desses eram membros do segmento dos usuários.

Figura 23 - Perfil sócio-demográfico dos conselheiros entrevistados do Conselho Gestor da Supervisão Técnica de Saúde de Vila Mariana, segundo segmento, São Paulo, 2006 e 2007.

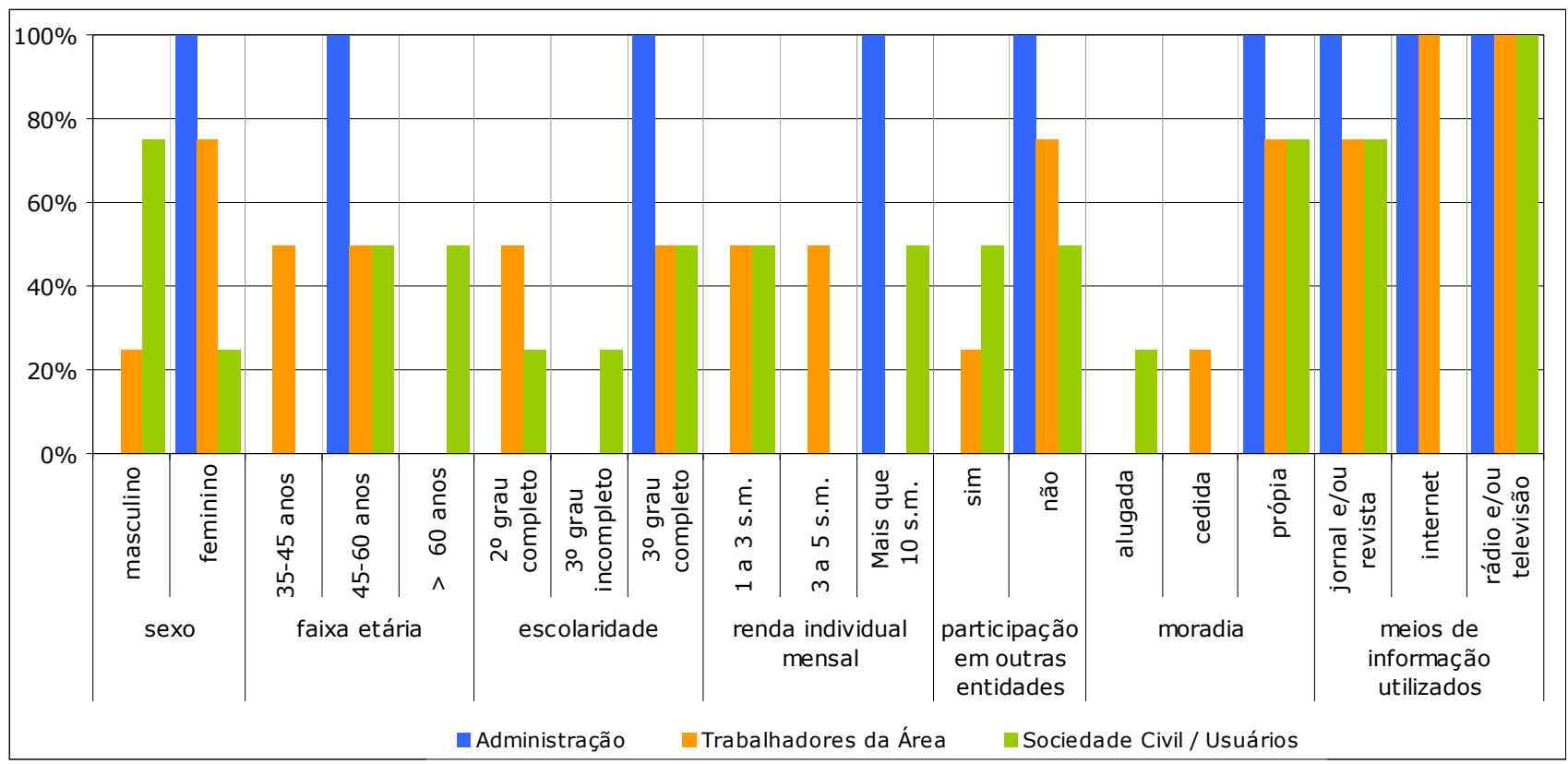

As mulheres constituíram $60 \%$ da composição do Conselho Gestor da Supervisão de Vila Mariana. Todos os conselheiros entrevistados possuem mais de 35 anos, sendo a faixa etária predominante de 45 a 60 anos.

O nível de escolaridade mais freqüentemente encontrado foi o $3^{\circ}$ grau completo ( $100 \%$ no segmento da administração, $50 \%$ no segmento dos trabalhadores e $50 \%$ no segmento dos usuários), sendo que $\circ 2^{\circ}$ grau completo apresentou uma porcentagem 
significativa também ( $50 \%$ no segmento dos trabalhadores e $25 \%$ no segmento dos usuários).

Quanto à renda encontraram-se dois extremos: $40 \%$ dos conselheiros entrevistados possuem renda menor que três salários mínimos e outros $40 \%$ possuem renda maior que dez salários mínimos. O restante ficou na faixa de três a cinco salários. Porém, na distribuição dessas porcentagens entre os segmentos, encontrou-se fato interessante: o segmento dos trabalhadores da área foi o que apresentou as menores faixas de renda, tendo $100 \%$ dos membros entrevistados apresentado renda de até cinco salários mínimos. Já no segmento dos usuários, encontraram-se dois pólos opostos, pois $50 \%$ possuem renda menor que três salários e os outros $50 \%$ possuem renda maior que dez salários mínimos. No segmento da administração todos possuem renda maior que dez salários mínimos. A maioria (80\%) dos conselheiros entrevistados possui moradia própria.

Sobre os meios de informação utilizados, todos os membros entrevistados referiram fazer uso da televisão e/ou do rádio, e a grande maioria também utiliza jornal e/ou revista (80\%) e a internet $(90 \%)$. Não foram citadas outras fontes. Ao serem questionados se esses meios de informação eram satisfatórios, $40 \%$ disseram que não, alegando que as fontes são incompletas ou são tendenciosas ou que não há uniformidade nas informações; desses membros, $50 \%$ eram do segmento dos usuários e $50 \%$ do segmento dos trabalhadores.

Considerando-se os dados da Fundação Seade ${ }^{8}$, com relação às condições de renda e escolaridade, os representantes dos usuários no Conselho de São Miguel Paulista são os que mais se

\footnotetext{
${ }^{8}$ Fonte: IBGE. Censo Demográfico 2000; Fundação Seade.
} 
diferenciam dos munícipes moradores dessa região: $14,6 \%$ dos moradores tem até onze anos de estudo e 75,84\% tem até três salários míninos, enquanto $50 \%$ dos membros do conselho tem pelo menos $2^{\circ}$ grau completo e $75 \%$ tem entre três e cinco salários mínimos.

No caso de Ermelino Matarazzo, 42,9\% dos usuários entrevistados têm $2^{\circ}$ grau completo e a maioria está na faixa de menos de três salários mínimos. Os dados referentes aos moradores da região indicam que apenas $18,6 \%$ tem pelo menos onze anos de estudo, mas, em termos de renda, igualmente aos conselheiros, $75 \%$ tem renda até três salários mínimos.

Finalmente, os conselheiros usuários de Vila Mariana são mais parecidos com os moradores da região, tanto com relação à escolaridade, quanto com relação à renda: $47,9 \%$ dos moradores e $50 \%$ dos conselheiros tem renda maior do que dez salários mínimos e $48,1 \%$ dos moradores e $50 \%$ dos conselheiros tem mais de doze anos de estudo.

É interessante perceber que as discrepâncias são maiores nas regiões mais carentes, enquanto na região mais central e que corresponde a uma das regiões mais privilegiadas da cidade, há maior proximidade entre os conselheiros e seus representados. Isso indica que o que prevalece é o fato dos conselheiros serem sempre pessoas mais preparadas e com mais recursos econômicos, ou seja pertencerem, considerando-se a situação geral do país, a uma elite (FUKS, PERISSINOTTO e RIBEIRO, 2003). 


\section{As entidades representadas}

No Conselho Gestor da Supervisão Técnica de Saúde de São Miguel Paulista percebeu-se que uma grande porcentagem dos entrevistados participa de alguma associação ou entidade $(57,1 \%)$, sendo que essa participação ficou mais concentrada no segmento dos usuários (75\%). Nenhum deles, porém, representa a associação ou entidade que participa no Conselho Gestor de São Miguel Paulista. No segmento dos usuários foram citadas duas associações de moradores e uma ligada ao movimento de moradia. Uma das conselheiras, além da associação de moradores também milita no Movimento de Saúde da Zona Leste. No segmento da administração, dos três entrevistados, um referiu participar de uma associação religiosa.

Percebeu-se que a minoria dos membros entrevistados $(26,7 \%)$ do Conselho de Ermelino Matarazzo, participa de alguma entidade ou associação. Nenhum membro entrevistado do segmento dos trabalhadores faz parte de entidades ou associações. No segmento da administração somente um dos membros entrevistados é filiado ao Sindicato dos Funcionários Públicos Municipais.

No segmento dos usuários, três membros entrevistados apontaram participar de entidades e/ou associações, mas apenas em dois casos indicaram que representam a referida entidade no Conselho: um é diretor da Regional Leste da Obra Kolping do Brasil e outro é membro da União dos Movimentos Populares de Saúde (UMPS) e, segundo seus relatos, as duas associações não estabelecem nenhum tipo de relação entre si. O outro membro participa de uma associação de moradores, mas não a representa no Conselho. 
Quadro 2 - Entidades e/ou associações representadas pelos conselheiros entrevistados do Conselho Gestor da Supervisão Técnica de Saúde de Ermelino Matarazzo, São Paulo, 2006 e 2007.

\begin{tabular}{|c|c|c|}
\hline Variável Associação & $\begin{array}{l}\text { União dos Movimentos } \\
\text { Populares de Saúde }\end{array}$ & Obra Kolping do Brasil \\
\hline \multirow{3}{*}{ Movimento } & $\begin{array}{l}\text { Participação popular na } \\
\text { gestão pública }\end{array}$ & $\begin{array}{l}\text { Questão urbana, inclusão } \\
\text { social e habitação }\end{array}$ \\
\hline & Saúde & Educação \\
\hline & Fóruns de mobilização civil & $\begin{array}{l}\text { Fóruns de mobilização } \\
\text { civil }\end{array}$ \\
\hline Área de atuação & Políticas públicas de saúde & Assistência social \\
\hline \multirow{2}{*}{$\begin{array}{l}\text { Objetivos } \\
\text { principais }\end{array}$} & $\begin{array}{l}\text { Melhoria dos serviços de } \\
\text { saúde }\end{array}$ & Mobilização social \\
\hline & $\begin{array}{l}\text { Extensão dos direitos } \\
\text { sociais }\end{array}$ & $\begin{array}{l}\text { Melhoria da qualidade de } \\
\text { vida }\end{array}$ \\
\hline \multirow[b]{2}{*}{$\begin{array}{l}\text { Principais } \\
\text { atividades } \\
\text { desenvolvidas }\end{array}$} & $\begin{array}{l}\text { Reuniões/plenárias/fóruns/ } \\
\text { discussões }\end{array}$ & \multirow{2}{*}{$\begin{array}{l}\text { Atividades de } \\
\text { capacitação e formação } \\
\text { (seminários / cursos / } \\
\text { palestras / congressos / } \\
\text { jornadas / oficinas / } \\
\text { alfabetização / projetos) }\end{array}$} \\
\hline & $\begin{array}{l}\text { Atividades de capacitação e } \\
\text { formação (seminários / } \\
\text { cursos / palestras / } \\
\text { congressos / jornadas / } \\
\text { oficinas / alfabetização / } \\
\text { projetos) }\end{array}$ & \\
\hline $\begin{array}{l}\text { Abrangência da } \\
\text { atuação }\end{array}$ & Nacional & Nacional \\
\hline $\begin{array}{l}\text { Número de } \\
\text { membros }\end{array}$ & Mais de 100 associados & Mais de 100 associados \\
\hline $\begin{array}{l}\text { A entidade tem } \\
\text { relação com } \\
\text { outras } \\
\text { associações? }\end{array}$ & Não soube responder & Sim \\
\hline Como? & Não se aplica & $\begin{array}{l}\text { Programas / campanhas } \\
\text { / projetos / eventos / } \\
\text { cursos / treinamento } \\
\text { (parcerias) }\end{array}$ \\
\hline
\end{tabular}

O conselheiro representante da UMPS, ao ser questionado sobre porque a associação em que participa tem interesse em estar no Conselho Gestor da Supervisão, afirmou que os objetivos dos Conselhos de Saúde são similares aos objetivos da UMPS e que sua participação na associação influencia muito sua atuação no 
Conselho.

Quanto à função que o conselheiro exerce e o tempo de participação na associação que representa no Conselho Gestor, identificou-se que o diretor da Obra Kolping participa há mais de cinco anos e o outro é membro há menos de um ano da União dos Movimentos Populares de Saúde (UMPS).

A área de atuação da UMPS corresponde à políticas públicas de saúde. Segundo o conselheiro entrevistado, os objetivos da UMPS são: melhorar e fortalecer o SUS e defender os direitos que o SUS oferece. Estes objetivos traduzem-se em: melhoria dos serviços de saúde e extensão dos direitos sociais, respectivamente. As principais atividades que são desenvolvidas para atingir os objetivos pretendidos são: a participação contínua em reuniões de conselhos em geral e o oferecimento de cursos. O conselheiro representante da UMPS não soube dizer se ela tem relações com outras associações e/ou entidades e justificou que não podia responder adequadamente pela associação, pois participa dela há pouco tempo.

A Obra Kolping do Brasil é uma associação alemã, fundada por padres da Igreja Católica e que se instala nos locais pela iniciativa de padres da região. Segundo o conselheiro entrevistado, a entidade trabalha nas comunidades na área social, isto é, assim como a maioria das associações ligadas à religião, atua na área de assistência social. O conselheiro entrevistado citou dois objetivos principais da associação que representa. O primeiro deles reflete imediatamente o viés religioso da associação: passar os ideais da Obra Kolping, que são religião, trabalho, recreação, família e sociedade - sendo categorizado como mobilização social; o segundo objetivo citado - promoção do trabalhador e sua família - 
também reflete um pouco o viés religioso (valorização da família), mas apresenta um objetivo mais específico à área da saúde que é a melhoria da qualidade de vida. As atividades desenvolvidas para atingir os objetivos da associação são atividades de capacitação e formação, sendo citadas: a formação de jovens, a capacitação profissional, cursos profissionalizantes, entre outras, a depender da realidade do local onde a associação está presente. A participação na Obra Kolping é voluntária e a escolha dos seus representantes para conselhos e fóruns dá-se por meio de eleição. Porém, o conselheiro entrevistado afirmou ter sido indicado pela direção da associação a participar do Conselho Gestor da Supervisão de Ermelino Matarazzo pelo fato de sempre ter sido muito atuante na região. A Obra Kolping possui relação com associações de bairro e prefeituras dos locais onde atua, principalmente, por meio da participação em eventos.

Confirma-se, assim, a análise de AVRITZER, RECAMÁN e VENTURI (2004), descrita anteriormente, quanto ao tipo de associativismo que permanece presente nos períodos de contração da "sanfona" de participação em São Paulo: entidades ligadas à religião e aos movimentos populares da área da saúde.

Encontrou-se, no Conselho Gestor da Supervisão Técnica de Saúde de Vila Mariana, que a maioria dos membros não participa de alguma entidade e/ou associação; e, dos poucos que participam, nenhum representa sua entidade ou associação no Conselho Gestor. Dentre o segmento da administração, ninguém participa; no segmento dos trabalhadores, a maioria (75\%) não participa - somente um membro participa de uma associação de moradores; no segmento dos usuários, $50 \%$ dos membros tem vínculo com uma entidade e/ou associação - faz parte de um 
grêmio recreativo de uma escola de samba, mas não o representam na composição do Conselho.

No trabalho publicado por LABRA (2008) encontrou-se que $70 \%$ das entidades representadas nos Conselhos Distritais de Saúde do município do Rio de Janeiro tem caráter comunitário ou popular (incluindo associações de moradores e uniões comunitárias) e $5 \%$ tem caráter religioso.

Neste estudo, se for desconsiderado que apenas em dois casos, os membros que pertencem ao segmento dos usuários dos Conselhos das Supervisões Técnicas de Saúde, referiram representar as entidades a que pertencem, e se tomar o conjunto das oito entidades a que estão vinculados os usuários, tem-se que sete delas podem ser categorizadas como comunitárias ou populares $(87,5 \%$ delas $)$ e uma é religiosa.

Outra observação a se fazer é que quando se comparam os dados desta investigação, feita nos anos de 2006 e 2007, quanto aos tipos de associações presentes nos Conselhos das Supervisões Técnicas de Saúde de São Miguel Paulista, Ermelino Matarazzo e Vila Mariana com dados de pesquisa de 2004 e 2005 de COELHO (2007) - tratando-se, portanto, de dois períodos consecutivos, mas diferentes, dos mandatos desses conselhos locais -, encontra-se diferença no número de categorias de associações nos Conselhos de São Miguel Paulista e de Vila Mariana. Em São Miguel Paulista, em 2004 e 2005, só foi encontrada um tipo de associação e, em 2006 e 2007, verificou-se a presença de pelo menos dois tipos de associações (associação de bairro e movimento por moradia), mesmo que ambas de caráter comunitário. Na Vila Mariana, o estudo de COELHO (2007) indicou a presença de seis tipos de associações, mas, em 2006 e 2007, só pôde ser identificado um 
tipo de associação (recreativa/comunitária). Apenas em Ermelino Matarazzo há coincidência de três tipos de associação nos dois períodos.

Como destacado por FUKS, PERISSINOTTO e RIBEIRO (2003), em qualquer análise sobre o vínculo entre associativismo e atuação política das pessoas é preciso considerar o tipo de associação a que pertencem: diferentes entidades com distintos objetivos e áreas de atuação e com formas diversas de organização interna produzem repercussões diferentes na formação política de seus membros. Assim, vale destacar que estão mais presentes as entidades voltadas para ações de melhoria na região em que atuam ou ligadas mais diretamente à questão de saúde.

\section{Participação e políticas públicas}

Nos três Conselhos Gestores, em todos os segmentos administração, trabalhadores e usuários - a maior parte dos entrevistados considerou que o Conselho influencia na formulação e implantação de políticas públicas. Vale destacar que foi no segmento dos usuários que a porcentagem de resposta afirmativa foi menor $(53,3 \%)$, o que indica maior descrença no potencial deliberativo dessa instância participativa. 
Figura 24 - Distribuição da percepção dos conselheiros entrevistados dos Conselhos Gestores das Supervisões Técnicas de Saúde quanto à influência e quanto à forma de influência do Conselho na formulação e implantação de políticas públicas, segundo segmento, São Paulo, 2006 e 2007.

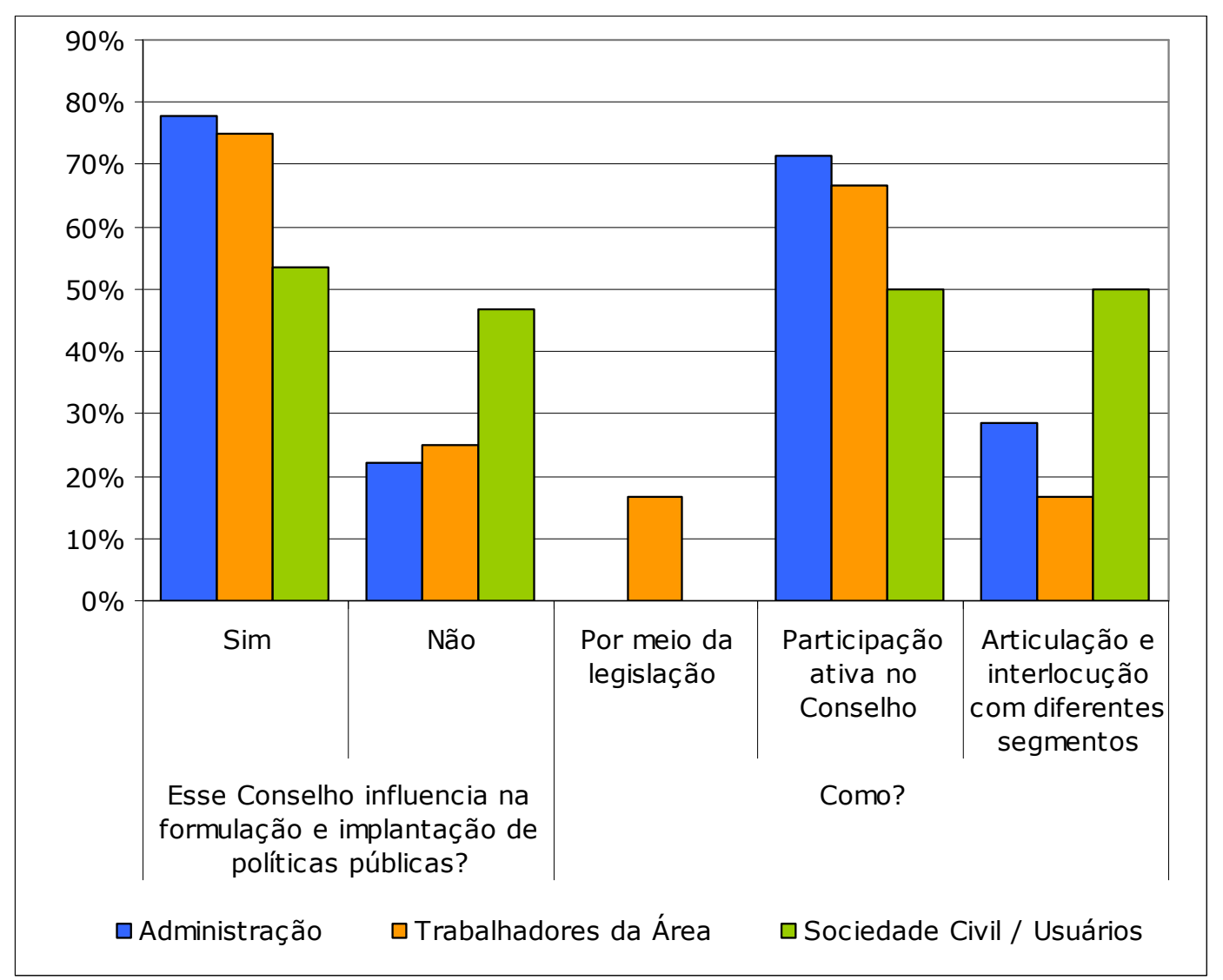

A forma de influência mais identificada nos três Conselhos foi a participação ativa no conselho: $71,4 \%$ no segmento da administração, $66,7 \%$ no segmento dos trabalhadores e $50 \%$ no segmento dos usuários. A outra forma de influência que aparece com destaque, considerando-se os três segmentos é a articulação e interlocução: $16,7 \%$ entre os membros da administração, $28,6 \%$ entre os membros dos trabalhadores da área e $50 \%$ entre os usuários. 
Figura 25 - Distribuição do conhecimento dos conselheiros entrevistados dos Conselhos Gestores das Supervisões Técnicas de Saúde sobre o funcionamento de outros conselhos gestores, segundo segmento, São Paulo, 2006 e 2007.

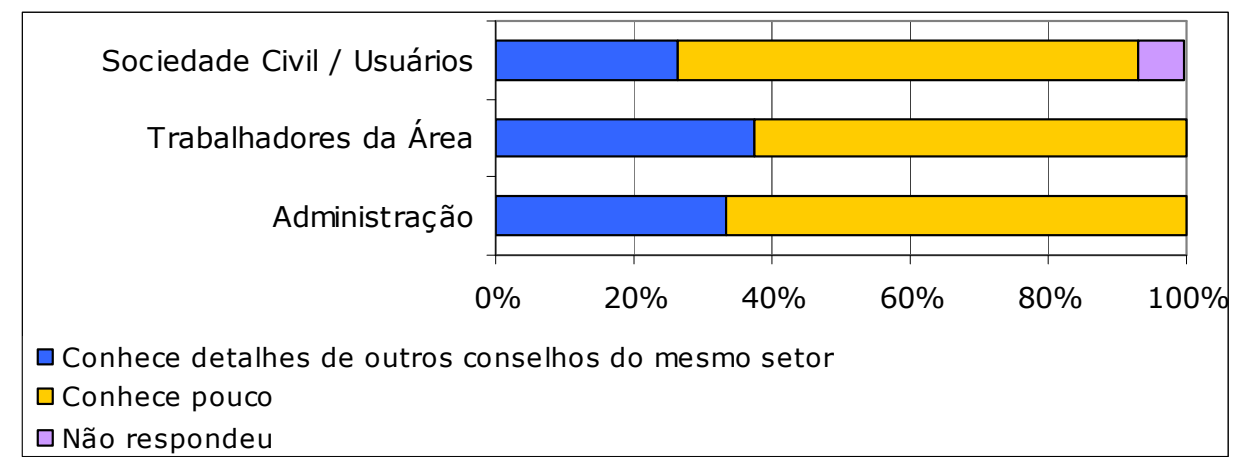

Assim como no caso dos Conselhos Municipais estudados, também entre os membros dos Conselhos das Supervisões Técnicas de Saúde há grande desconhecimento quanto ao funcionamento de outras instâncias participativas, dificultando entendimento quanto às possíveis formas de encaminhamento de políticas públicas integradas.

Figura 26 - Distribuição da percepção dos conselheiros entrevistados dos Conselhos Gestores das Supervisões Técnicas de Saúde quanto à influência do Conselho na formulação e implantação de políticas públicas integradas e intersetoriais, segundo segmento, São Paulo, 2006 e 2007.

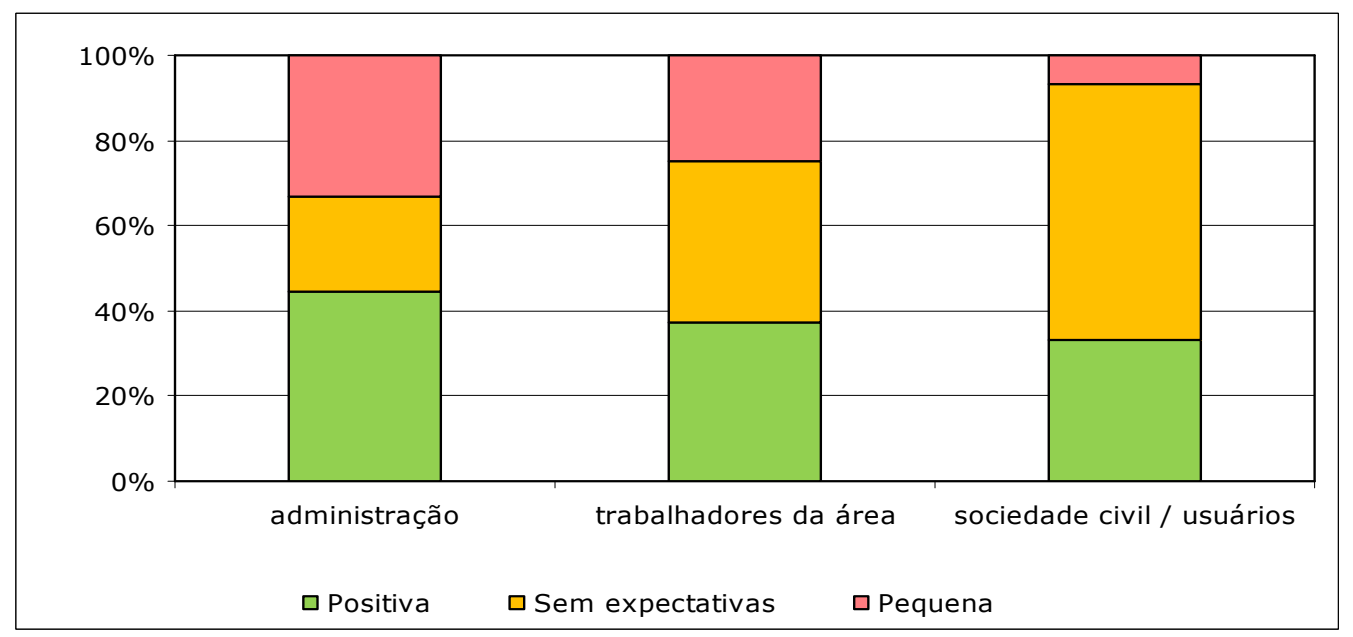


A expectativa quanto à influência do Conselho na formulação e implantação de políticas públicas integradas e intersetoriais é pequena e, em especial, entre os usuários, transparece significativa descrença (60\% respondeu que não tem expectativa, 6,7\% tem expectativa pequena e apenas $33,3 \%$ tem expectativa positiva). É interessante referir que o segmento da administração é o que apresenta maior expectativa positiva $(44,4 \%)$.

As justificativas elencadas foram: a dificuldade de articulação e integração com outros setores e instâncias governamentais e não governamentais (segmento da administração - 33,3\%; segmento dos trabalhadores - 50\% e segmento dos usuários - 33,3\%); a fase de formação em que o Conselho ainda se encontra, ou seja o caráter incipiente dessa instância institucional de participação, incluindo a falta de plano de ação estratégico para os Conselhos (segmento da administração - 22,2\% e segmento dos usuários $20,1 \%$ ) e o fato de que, segundo percepção dos trabalhadores e usuários, efetivamente a instância de decisão está fora do âmbito do conselho (12,5\% e $13,3 \%$, respectivamente).

Tanto no caso da influência sobre a definição de políticas públicas, em geral, ou integradas e intersetoriais, há coincidência com os resultados encontrados junto aos Conselhos Municipais: percepção de maior influência junto às políticas públicas em geral e menor influência nas políticas integradas e intersetoriais. As justificativas também são similares, revelando percepção acurada quanto à dinâmica da gestão e às limitações dos setores e dos atores sociais no que diz respeito ao desenvolvimento de ações conjuntas. 
Figura 27 - Distribuição da percepção dos conselheiros entrevistados dos Conselhos Gestores das Supervisões Técnicas de Saúde quanto à existência de políticas intersetoriais e como foram formuladas e implantadas, segundo segmento, São Paulo, 2006 e 2007.

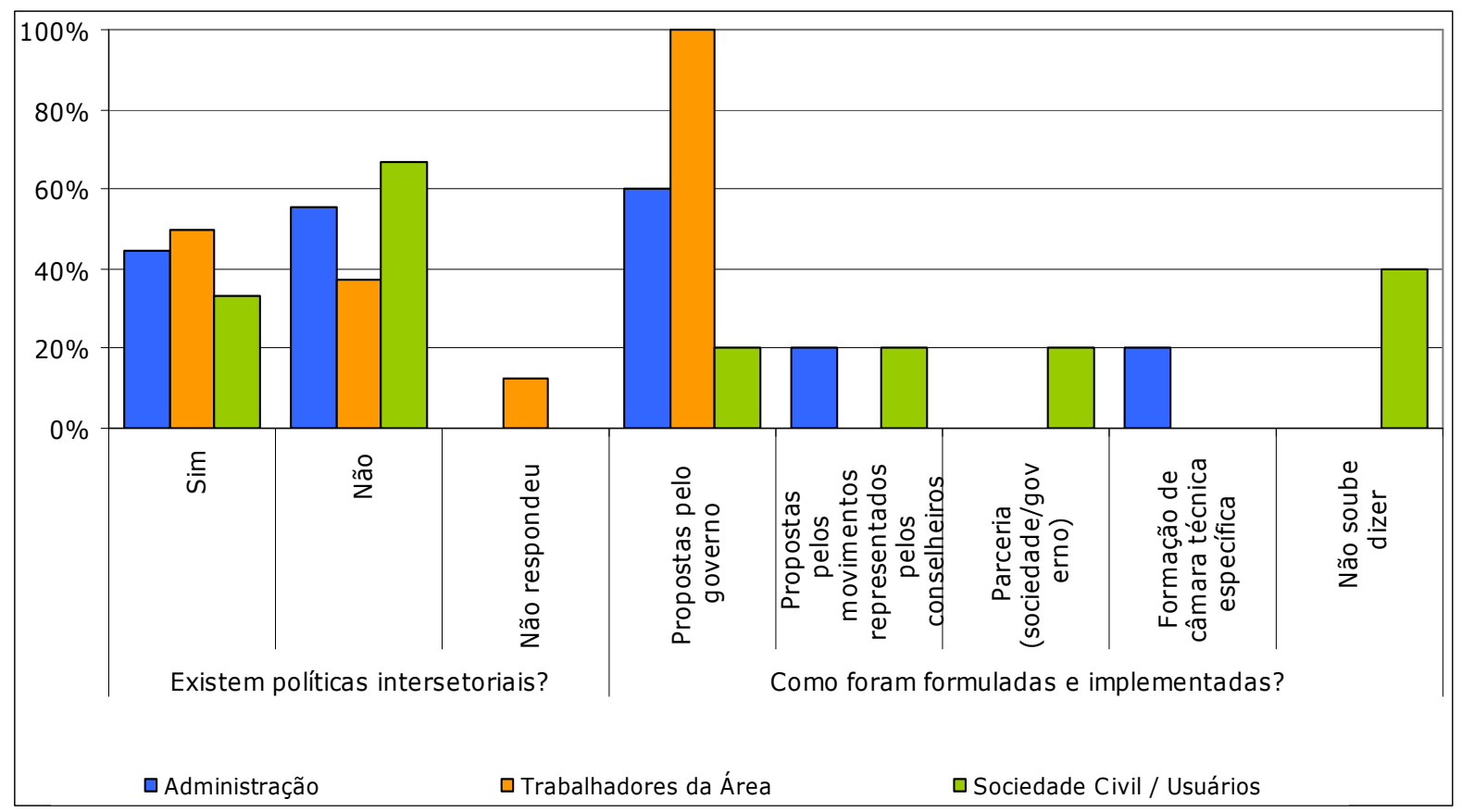

Menos da metade dos respondentes dos segmentos da administração (45\%) e usuários (33,3\%) indicou a existência de políticas intersetoriais em algum nível (municipal, regional ou local); entre os trabalhadores, metade indicou que elas existem. Chama a atenção o fato de que apenas duas foram claramente nominadas - Campanha de Combate à Dengue e Pacto pela Saúde -. As outras referências são bastante genéricas - Programas educacionais, Programas ambientais e Programas de assistência social.

Quanto à identificação de quais são políticas intersetoriais, os membros dos Conselhos Locais apresentaram mais limitações, provavelmente porque as discussões nos seus conselhos ficam 
mais restritas às ações e aos programas de saúde. Por outro lado, o fato de serem Conselhos Locais poderia permitir terem foco no território, enquanto espaço físico e social, e se voltarem para a articulação das ações setoriais, na perspectiva da intersetorialidade e na combinação de estratégias voltadas à promoção, à proteção, à prevenção e à recuperação das condições de saúde (CHIESA e KON, 2007).

Quanto aos procedimentos de formulação e implantação, o mais mencionado, pelos que responderam à questão, nos segmentos da administração e dos trabalhadores é que as propostas são apresentadas pelo poder público/governo (segmento da administração - $60 \%$ e segmento dos trabalhadores - 100\%), o que indica papel pouco propositivo dos demais segmentos e entidades/associações representadas pelos membros. Por outro lado, apesar da maior parte dos usuários (40\%) ter referido que não sabia responder como as políticas foram formuladas ou implantadas, as respostas dos demais indicaram tanto que são propostas pelo governo (20\%) ou que partiram dos movimentos presentes de alguma forma nos Conselhos (20\%) ou que são resultado de parceria entre sociedade e governo (20\%). Aí aparecem como mais propositivos os segmentos da administração e dos usuários, transparecendo que os trabalhadores, no caso dos Conselhos Locais, têm atuação mais discreta, condizente com o fato de que nesses Conselhos é inexistente a representação sindical ou de entidades de classe, como ocorre nos Conselhos Municipais. 
4.3 ANÁLISE DE AGRUPAMENTO JUNTO AOS CONSELHOS MUNICIPAIS E CONSELHOS GESTORES ESTUDADOS

Por meio de uma primeira análise de agrupamento (Cluster) foi possível identificar a existência de um grupo - cluster 4 - que, embora reúna um pequeno número de pessoas $(n=6,6,7 \%)$, apresenta características típicas e diferenciadas, do ponto de vista de significação estatística, do restante do universo de conselheiros estudados.

As características são: idosos, com média de idade de 73,7 anos (com desvio padrão de 4,97); que não trabalham fora de casa e utilizam, predominantemente, outros meios de comunicação (que não rádio, televisão, jornal ou internet) para terem acesso à informação. Os sujeitos que compõem esse grupo não têm expectativa de que o Conselho em que participam influencie na formulação e implantação de políticas públicas integradas e intersetoriais. Ao mesmo tempo, entendem que participar do Conselho significa pensar na coletividade e oferece-lhes a oportunidade de reivindicar que os benefícios produzidos socialmente sejam compartilhados pela sociedade.

Verificou-se que $o$ pertencimento a algum segmento (sociedade civil, trabalhadores ou administração) ou a algum tipo de conselho (municipais ou locais) não caracteriza as pessoas desse grupo, indicando que tais comportamentos, identificados como típicos, estão espalhados aleatoriamente pelos seis conselhos estudados e pelos três segmentos que os compõem.

Apesar de se poder caracterizar o grupo dos conselheiros estudados como um grupo maduro, considerando as faixas etárias 
predominantes, essas seis pessoas estão acima da média de idade encontrada. Aparentam considerar a participação de cada um no Conselho como um compromisso pessoal, em função de seus valores, ao mesmo tempo em que se mostram céticos quanto ao potencial de atuação dos Conselhos.

Figura 28 - Representação dos Agrupamentos encontrados na primeira análise de agrupamento dos Conselhos Municipais e Conselhos Gestores das Supervisões Técnicas de Saúde, São Paulo, 2006 e 2007.

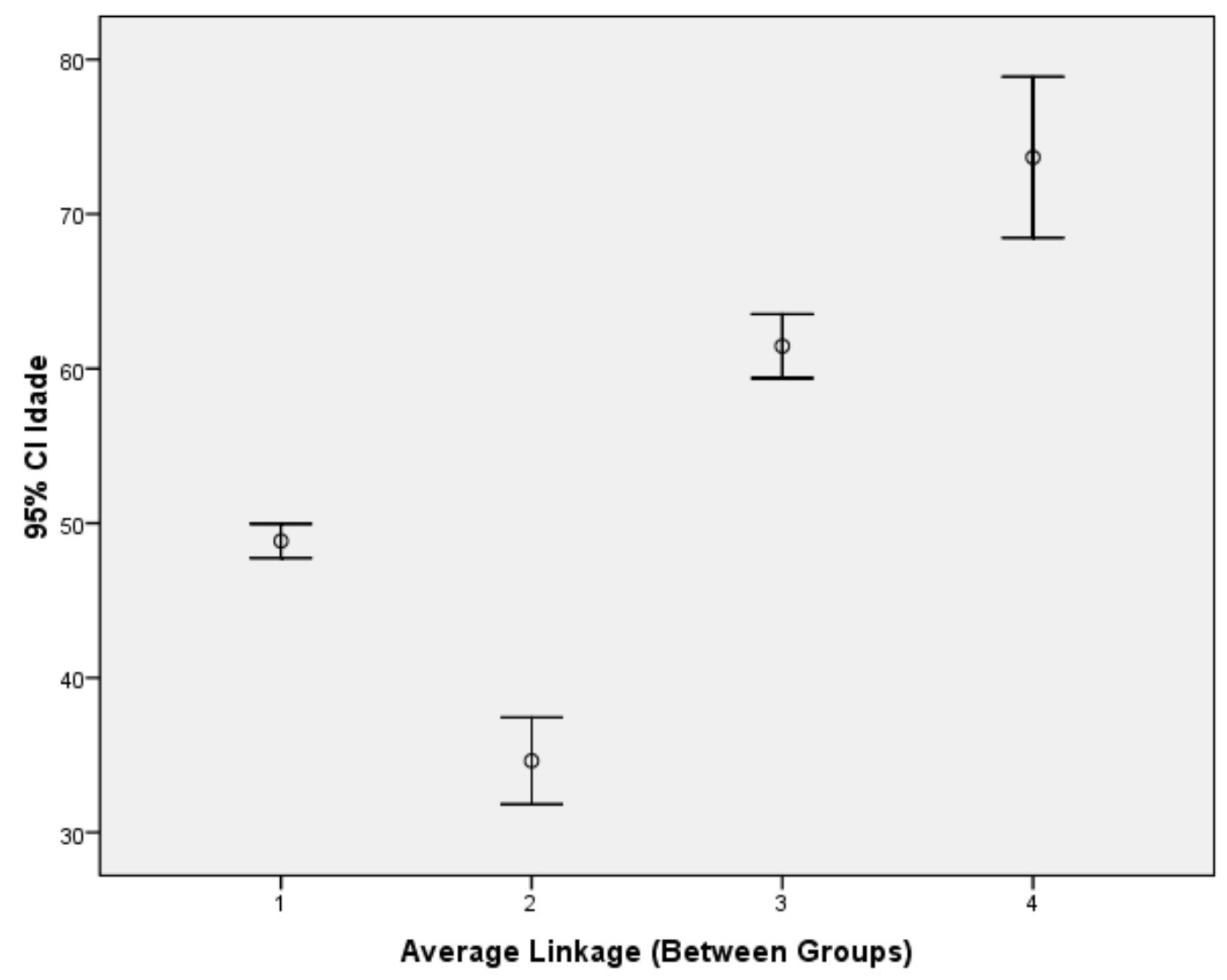

Em seguida, processou-se nova análise para buscar identificar a existência de outros agrupamentos, excluindo-se os seis indivíduos que compunham o cluster 4 encontrado. 
Por meio desse procedimento, foi possível encontrar, com significação estatística, dois grupos diferenciados apenas pela variável idade. Um dos grupos tem 69 pessoas, com média de 51,3 anos (desvio padrão de 6,46) e o outro grupo é composto por 15 conselheiros, com idade média de 34,2 anos (desvio padrão de $5,17)$. Nenhuma outra das variáveis selecionadas como mais discriminatórias indicou qualquer comportamento típico.

Figura 29 - Representação dos Agrupamentos encontrados na segunda análise de agrupamento dos Conselhos Municipais e Conselhos Gestores das Supervisões Técnicas de Saúde, São Paulo, 2006 e 2007.

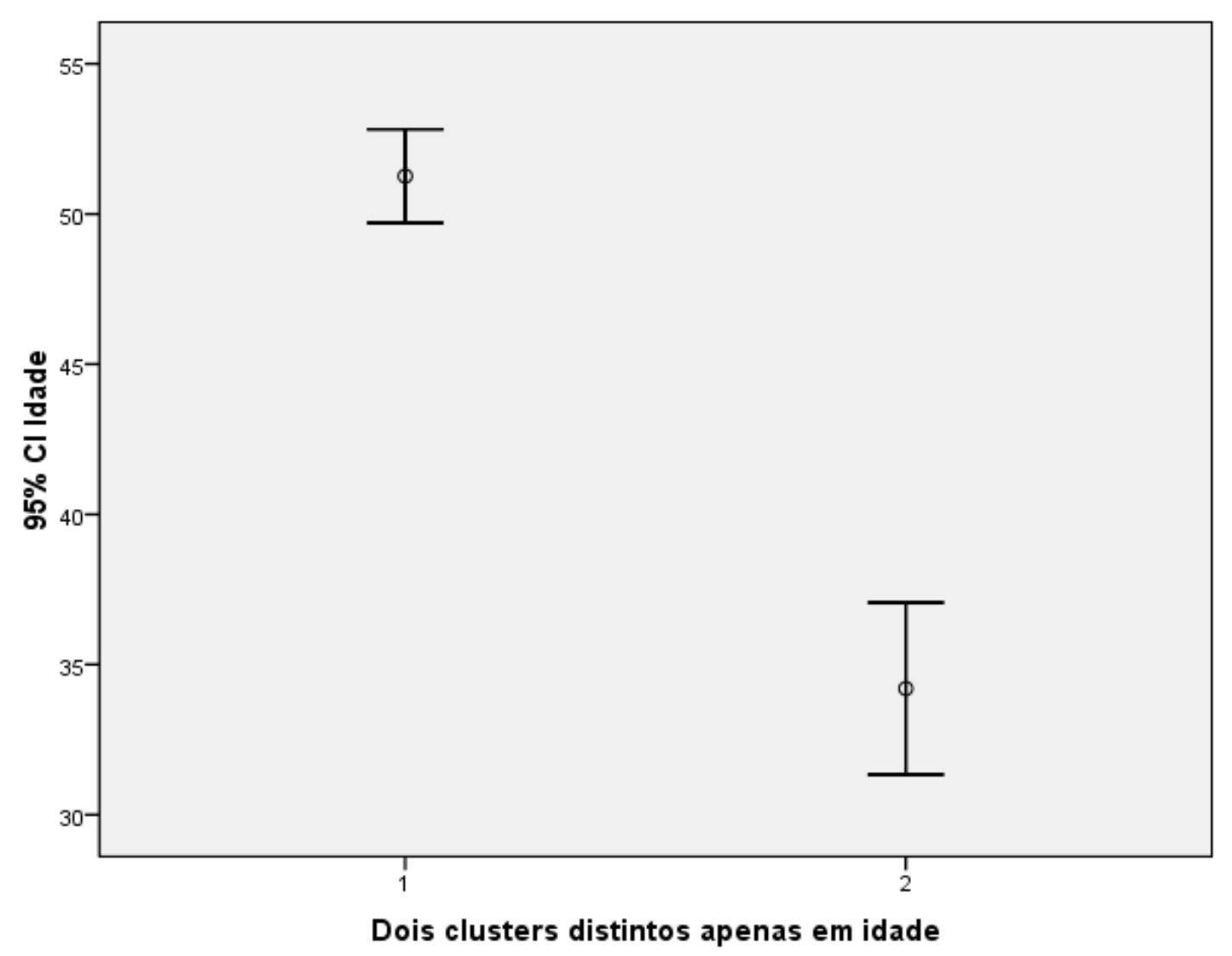

O resultado obtido é bastante interessante quanto aos dois aspectos que se destacam: a grande uniformidade entre os conselheiros estudados - o que pode indicar que há um padrão de 
comportamento que está fortemente estabelecido e disseminado entre os que militam nos fóruns participativos institucionalizados e que se desponta um grupo de conselheiros mais jovens (aproximadamente $17 \%$ do total de conselheiros entrevistados), na faixa etária dos 30 anos com, possivelmente, ainda longo período de atuação nesse tipo de espaço participativo e cuja vivência quanto aos processos políticos nacionais é distinta da maior parte dos membros que, atualmente, compõem os Conselhos. Isso indica que investigar de forma mais aprofundada a questão geracional e suas repercussões pode trazer novos elementos para a compreensão do fenômeno dos Conselhos Gestores de Políticas Públicas. 

5. CONSIDERAÇÕES FINAIS

\begin{abstract}
Entardeço sem ênfase. Não sei fechar um livro

Ou vedar uma frase. [...]

Avançar uma página é retornar ao princípio.
\end{abstract}

Biografia de uma árvore - Fabrício Carpinejar 



\section{CONSIDERAÇÕES FINAIS}

Com a criação dos Conselhos Gestores, a população teve, por meio desses espaços, a possibilidade de participação em decisões, antes exclusiva do poder executivo governamental, o que significa um avanço nos processos democráticos. No entanto, os Conselhos Gestores de políticas públicas são ainda instâncias recentes que precisam ser aprimoradas e valorizadas junto à sociedade, a fim de que o controle social e a participação social na formulação e implantação de políticas públicas sejam realmente efetivados.

A temática da participação social envolve aspectos que são dinâmicos porque são decorrentes da forma como se estabelecem as relações entre grupos sociais com níveis de poder e interesses diferentes.

O estudo dos seis conselhos gestores de políticas públicas: três do nível municipal, referentes às temáticas de meio ambiente e desenvolvimento sustentável, saúde e segurança alimentar nutricional, e três do nível local, específicos do setor saúde, indicaram que, de forma geral, o perfil sócio-demográfico dos conselheiros do segmento da sociedade civil não tem correspondência com as características da maior parte da população a ser representada nesses fóruns porque os membros presentes nos Conselhos têm melhores condições sócioeconômicas.

Verificou-se que os conselheiros do COMUSAN e do CADES têm caráter mais homogêneo quanto ao grau de instrução e à renda, enquanto no CMS, essas características são mais diversificadas. 
Em todos os Conselhos, encontrou-se que os segmentos da administração e dos trabalhadores da área são compostos por pessoas com melhores condições de renda e escolaridade, em comparação com os membros da sociedade civil.

Com relação à idade tem-se que os conselheiros são, na sua maioria, adultos na faixa etária dos 45 aos 60 anos, ou seja, pessoas maduras.

No caso do segmento da sociedade civil, os conselheiros têm experiência anterior e atual na participação em entidades e/ou associações da sociedade civil, mesmo que não se coloquem, explicitamente, como representantes das mesmas nas vagas que ocupam nos Conselhos.

A forma de escolha dos conselheiros para os mandatos interfere na representatividade dos Conselhos, dependendo do maior ou menor envolvimento da população nesses processos e constatou-se que acontecem de forma diferente. No CADES, os segmentos dos trabalhadores e dos usuários realizam discussões dentro das instituições que militam na área e indicam nomes que devem homologados pelo poder executivo. No CMS e no COMUSAN, conferências municipais ocorrem periodicamente; nesses eventos são eleitas as entidades e/ou associações para representarem os segmentos da sociedade civil e dos trabalhadores e então as pessoas são definidas dentro de cada entidade. No caso dos Conselhos Gestores das Supervisões Técnicas de Saúde, os membros da sociedade civil vêm dos Conselhos das Unidades de Saúde e os do segmento dos trabalhadores são definidos pelos membros da categoria que atuam dentro da Supervisão de Saúde.

Identificou-se que a representação vinculada a entidades e/ou associações está presente e claramente definida nos 
Conselhos Municipais, tanto no caso do segmento da sociedade civil, quanto no caso do segmento dos trabalhadores. Entretanto, essa vinculação é precariamente estabelecida, nos Conselhos Gestores Locais da área de saúde, apesar de haver referência a esse tipo de representação nos seus Regimentos Internos. Já entre os membros do segmento da administração, em todos os conselhos, há poucos relatos de algum tipo de associativismo civil.

A partir da análise das entidades e/ou associações presentes nos Conselhos Municipais e as relações que indicaram manter com outras, constatou-se potencialidade quanto à existência de redes entre associações que partilham mesma área de atuação e têm objetivos comuns.

As entidades e associações representadas no CADES são majoritariamente vinculadas à defesa de interesses de classe, o que também acontece no COMUSAN. No CMS, as entidades e associações atuam, principalmente, na área das políticas públicas de saúde, por meio da mobilização social.

Com relação à atuação dos Conselhos - municipais e locais na articulação e formulação de políticas públicas, em geral, e intersetoriais, especificamente, a percepção dos conselheiros é de que existem possibilidades para isso mas, concretamente, as experiências são incipientes e existem aspectos de contexto que impõem limitações para isso ocorrer efetivamente, desde o nível local até o municipal.

São precários os conhecimentos sobre estrutura e funcionamento de instâncias de participação institucionais e mecanismos de formulação e proposição de políticas, dificultando as práticas de integração e interlocução entre os segmentos que participam dos Conselhos e desses com outros conselhos e com 
outros setores.

De forma geral, os dados coletados, por meio das entrevistas individuais realizadas com cerca de $30 \%$ dos membros dos Conselhos estudados, apontaram para um alto grau de homogeneidade entre os conselheiros, o que a análise de agrupamento corroborou.

A partir dos resultados obtidos e abordados na discussão, pode-se destacar que aspectos relativos à representatividade dos Conselhos ainda não foram solucionados. Uma das expectativas com relação à criação e instalação dos Conselhos era de que isso ampliaria o número de pessoas a se envolverem e acompanharem discussões e decisões relativas às políticas públicas de seu interesse, incluindo os mais diversos grupos sociais. Sem dúvida, ampliou-se o número de pessoas e diferentes atores societários fazem parte dessas instâncias, mas não de forma suficiente para ter um caráter universalista e incluir os mais variados segmentos da população brasileira, incluindo os grupos socialmente mais desfavorecidos.

Essa limitação que ocorre nos Conselhos é decorrência de processo similar que se dá no âmbito da sociedade civil, no que diz respeito às relações, muitas vezes também frágeis, entre organizações civis e os grupos e segmentos sociais que pretendem representar.

Por outro lado, é imprescindível reconhecer que as organizações civis têm estabelecido entre si redes associativas que já têm ampliado o alcance e a repercussão da discussão de algumas temáticas e aí há enorme potencial para democratizar os fóruns participativos.

Além disso, o aprimoramento e a consolidação dos próprios 
conselhos de políticas públicas das áreas sociais podem levá-los a se constituírem em rede e atuarem como instâncias de articulação, com uma perspectiva intersetorial, para auxiliar na resolução de problemas complexos que caracterizam o espaço urbano, afetam as condições de saúde da população e dependem de ações integradas entre várias áreas da administração e da sociedade.

Outro aspecto que ainda aparece como um problema nas instâncias participativas é o não cumprimento de seu caráter deliberativo quanto à elaboração de políticas públicas.

Há que se considerar, como mostraram os resultados desta investigação, que faltam aos conselheiros, conhecimentos, recursos argumentativos e força política para se posicionarem nas decisões dos Conselhos. Em muitas situações, as exigências de capacitação técnica e política estão além das suas possibilidades.

Em função das questões levantadas e considerando-se que os espaços e instâncias participativas estão consolidados institucionalmente e precisam ser mais qualificados, a formação das pessoas que ocupam ou que virão a ocupar esses espaços é apontada como necessária.

O despreparo para a atuação nos conselhos e outros fóruns participativos é característica de todos os segmentos, mesmo que por razões diversas: desde o não acesso a informações até o não reconhecimento do outro como interlocutor. Processos de capacitação de conselheiros resultarão em melhor desempenho se contemplarem, nas suas propostas de cursos, conteúdos voltados para uma formação política geral, sem deter-se, exclusivamente, em aspectos específicos ligados à área de atuação do conselho.

$\mathrm{Na}$ medida em que a maior parte das capacitações de conselheiros é destinada para os que já são membros de conselhos 
tem-se o risco de criar um grupo elitizado que tenderia a perpetuar-se nas instâncias participativas. O problema a ser equacionado é como fazer para ampliar a participação e não reproduzir mecanismos de exclusão social presentes na sociedade brasileira. Esse é um desafio a ser superado que vai além do âmbito dos conselhos gestores de políticas públicas, pois se refere à extensão da formação de cidadania. Com essa preocupação e levando-se em conta a ampliação e a capilaridade das mais diversas experiências associativas no meio urbano, pode ser interessante o desenvolvimento de iniciativas de formação dirigidas também a instituições e associações que estão fora do sistema político tradicional, tais como associações de bairro, com a participação das mesmas, desde a definição de objetivos, desenvolvimento do planejamento e execução das atividades.

Tais ações, voltadas para o aperfeiçoamento dos espaços participativos e coletivos para a formulação e implantação de políticas públicas sociais, podem ter como referências os elementos fundamentais do paradigma da promoção da saúde que são: (1) a ampliação de abrangência de políticas públicas, voltadas exclusivamente para o setor saúde, advogando em nome de políticas públicas intersetoriais com maior capacidade de intervenção sobre os condicionantes sócio-ambientais de saúde (denominadas, então, de políticas públicas saudáveis) e (2) o fortalecimento da ação comunitária que envolve, tanto a participação social, aglutinando atores da sociedade civil e do Estado, quanto o empowerment individual e coletivo para lidar com a multiplicidade de condicionantes da saúde.

Passa-se a ter como referência a qualidade de vida, que é um denominador comum nos discursos de vários setores, o que auxilia 
a superação de uma compreensão fragmentada das políticas públicas e dos processos envolvidos na sua elaboração. Além disso, no âmbito da promoção da saúde, processos educativos são valorizados, privilegiando-se metodologias participativas e ativas, pois a disseminação da informação e a educação são bases para os processos decisórios. 

6. REFERÊNCIAS 



\section{REFERÊNCIAS}

Abers RN, Keck ME. Representando a diversidade: Estado, sociedade e "relações fecundas" nos conselhos gestores. Cad. CRH. 2008; 21(52): 99-112.

Assis MMA, Villa TCS. O controle social e a democratização da informação: um processo em construção. Rev Latino-am Enfermagem. 2003; 11(3): 376-82.

Avritzer L. Associativismo e participação na saúde: uma análise da questão na região Nordeste do Brasil. In: Fleury S, Lobato LVC. (Orgs.). Participação, democracia e saúde. Rio de Janeiro: Cebes; 2009. p. 151-74.

Avritzer L, Recamán M, Venturi G. O Associativismo em São Paulo. In: Avritzer L. (Org.). A participação em São Paulo. São Paulo: UNESP; 2004. p. 11-57

Ayuste A, Flecha R, López Palma F, Lleras J. Planteamientos de la pedagogía crítica: comunicar y transformar. Barcelona: Graó Editorial; 1994.

Baquero M. Democracia, participação e capital social no Brasil hoje. In: Fleury S, Lobato LVC. (Orgs.). Participação, democracia e saúde. Rio de Janeiro: Cebes; 2009. p. 129-50.

Bógus CM. Participação popular em saúde. São Paulo: Annablume Fapesp; 1998.

Bógus CM. Os conselhos de saúde e o fortalecimento da democracia brasileira. Mundo Saúde. 2005; 29(29): 41-8.

Bógus CM. A educação popular em saúde como possibilidade para o incremento do controle social no setor saúde. Mundo Saúde. 2007; 31(3): 346-54.

Borges SFM. Participação social, associativismo de vizinhança e conselhos de saúde: estudo sobre as associações de moradores e seus representantes nos conselhos distritais de saúde do município do Rio de Janeiro [Dissertação de Mestrado]. Rio de Janeiro: Escola Nacional de Saúde Pública Sergio Arouca; 2004.

Brasil. Decreto 99.438, de 7 de agosto de 1990a. Dispõe sobre a organização e atribuições do Conselho Nacional de Saúde, e dá outras providências. [lei na internet]. [acesso em 07 ago 2009]. Disponível em:

http://www.jusbrasil.com.br/legislacao/114148/decreto-99438-90 
Brasil. Lei no 8.080, de 19 de setembro de 1990b. Dispõe sobre as condições para a promoção, proteção e recuperação da saúde, a organização e o funcionamento dos serviços correspondentes e dá outras providências. [lei na internet]. [acesso em 07 ago 2009]. Disponível em: http://www.planalto.gov.br/ccivil_03/Leis/L8080.htm

Brasil. Lei no 8.142, de 28 de dezembro de 1990c. Dispõe sobre a participação da comunidade na gestão do Sistema Único de Saúde (SUS) e sobre as transferências intergovernamentais de recursos financeiros na área da saúde e dá outras providências. [lei na internet]. [acesso em 07 ago 2009]. Disponível em:

http://www.pge.sp.gov.br/centrodeestudos/bibliotecavirtual/dh/vol ume\%20i/saudelei8142.htm

Brioschi LR, Trigo MHB. Relatos de vida em ciências sociais: considerações metodológicas. Cienc. Cult. 1987; 39: 631-7.

Bussab WO, Morettin PA. Estatística básica. 5. ed. São Paulo: Saraiva; 2002.

Carvalho AI. Conselhos de saúde, participação social e a reforma do Estado. Ciênc. saúde coletiva. 1998; 3(1): 23-6.

Carvalho SR. Os múltiplos sentidos da categoria "empowerment" no projeto de Promoção da Saúde. Cad. Saúde Pública. 2004; 20(4): 1088-95.

Chiesa AM, Kon R. Compreensão do território: instrumento de gestão em atenção primária à saúde. In: Santos AS, Miranda SMRC. A enfermagem na gestão em atenção primária à saúde. Barueri: Manole; 2007. p. 309-22.

Coelho VSP, Nobre M. Participação e deliberação: teoria democrática e experiências institucionais no Brasil contemporâneo. São Paulo: Editora 34; 2004. Apresentação. p. 11-8.

Coelho VSP, Veríssimo J. Considerações sobre o processo de escolha dos representantes da sociedade civil nos conselhos de saúde em São Paulo. In: Avritzer L. (Org.). A participação em São Paulo. São Paulo: UNESP; 2004. p. 105-22.

Coelho VSP. A democratização dos conselhos de saúde. Novos estud.- CEBRAP. 2007; 78:77-92.

Coelho VSP. Conselhos de saúde enquanto instituições políticas: o que está faltando? In: Coelho VSP, Nobre M. (Orgs.). Participação e deliberação: teoria democrática e experiências institucionais no Brasil contemporâneo. São Paulo: Editora 34; 2004. p. 255-69. 
Comerlatto D, Colliselli L, Kleba ME, Matiello A, Renk EC. Gestão de políticas públicas e intersetorialidade: diálogo e construções essenciais para os conselhos municipais. Rev. Katálysis. 2007; 10(2): 265-71.

Côrtes SM. As origens da idéia de participação na área de saúde. Saúde em Debate. 1996; 51: 30-7.

Côrtes SM. Fóruns participativos e governança: uma sistematização das contribuições da literatura. In: Lubambo C, Côelho DB, Melo MA. (Orgs.). Desenho institucional e participação política: experiências no Brasil contemporâneo. Petrópolis: Vozes; 2005. p. 13-32.

Costa CGA. Segurança alimentar e nutricional: significados e apropriações [Dissertação de Mestrado]. São Paulo: Faculdade de Saúde Pública da USP; 2008.

Cruz Neto O. O trabalho de campo como descoberta e criação. In: Minayo MCS (Org.). Pesquisa social: teoria, método e criatividade. 2. ed. Petrópolis: Vozes; 1995. p. 51-66.

Dagnino E. Sociedade civil, espaços públicos e a construção democrática no Brasil: limites e possibilidades. São Paulo: Paz e Terra; 2002. Sociedade civil e espaços públicos no Brasil. p. 279301.

Delgado M, Escorel S. Perfil dos conselhos estaduais de saúde: as singularidades e similaridades no controle social. Divulg. Saúde Deb. 2008; 43: 62-78.

Dombrowski O. Poder local, hegemonia e disputa: os conselhos municipais em pequenos municípios do interior. Rev. Sociol. Polit. 2008; 16(30): 269-81.

EPI INFO ${ }^{\mathrm{TM}}$ for DOS, version 3.3.2. Atlanta: Centers for Disease Control and Prevention - Division of Public Health Surveillance and Informatics; 2005.

Escorel S, Delgado M. Ensaio sobre a Resolução 333/03 do CNS: entre as dimensões política e técnica e entre as dinâmicas participativa e fiscalizatória. Divulg. Saúde Deb. 2008; 43: 79-95.

Etcheverry CAL. Sociedad civil y participación ciudadana - cómo los actores sociales se hacen parte de las decisiones. Interações (Campo Grande). 2008; 9(2): 181-8.

Faria CAP. Idéias, conhecimento e políticas públicas: um inventário sucinto das principais vertentes analíticas recentes. Rev. bras. Ci. Soc. $2003 ;$ 18(51): 21-30. 
Ferreira MC. Associativismo e contato político nas regiões metropolitanas do Brasil: 1988-1996. Revisitando o problema da participação. Rev. bras. Ci. Soc. 1999; 14(41): 90-102.

Ferreira MS, Castiel LD. Which empowerment, which Health Promotion? Conceptual convergences and divergences in preventive health practices. Cad. Saúde Pública. 2009; 25(1): 6876.

Fuks M, Perissinotto R. Recursos, decisão e poder: conselhos gestores de políticas públicas de Curitiba. Rev. bras. Ci. Soc. 2006; 21(60): 67-81.

Fuks M, Perissinotto RM, Ribeiro EA. Cultura política e desigualdade: o caso dos Conselhos Municipais de Curitiba. Rev. Sociol. Polit. 2003; 21: 125-45.

Gerschman S. Conselhos Municipais de Saúde: atuação e representação das comunidades populares. Cad. Saúde Pública. 2004; 20(6): 1670-81.

Gohn MG. Papel dos conselhos gestores na gestão pública. 2. ed. Informativo CEPAM - Conselhos municipais das áreas sociais. 2002; 1(3): 7-16.

Gohn MG. Conselhos gestores e participação sociopolítica. 2. ed. São Paulo: Cortez; 2003a.

Gohn MG. Associativismo civil, conselhos de gestão na saúde e as cidades brasileiras. In: Rassi Neto E, Bógus CM. (Orgs.). Saúde nos grandes aglomerados urbanos: uma visão integrada. Brasília (DF): OPAS; 2003b. p. 41-65.

Gohn MG. O protagonismo da sociedade civil: movimentos sociais, ONG's e redes solidárias. São Paulo: Cortez; 2005.

Haguette TMF. Metodologias qualitativas na sociologia. Petrópolis: Vozes; 1990.

Jacobi P. Políticas sociais e ampliação da cidadania. Rio de Janeiro: FGV Editora; 2000.

Junqueira LAP. Conselhos municipais e a gestão em rede das políticas sociais. 2 . ed. Informativo CEPAM - Conselhos municipais das áreas sociais. 2002; 1(3): 26-31.

Junqueira LAP. Intersetorialidade, transetorialidade e redes sociais na saúde. Rev. Adm. Publica. 2000; 34(6): 35-45.

Koga D. Medidas de cidades: entre territórios de vida e territórios vividos. São Paulo: Cortez; 2003. 
Labra ME. Análise de Políticas, Modos de Policy-Making e Intermediação de Interesses: uma revisão. Physis. 1999; 9(2): 131-66.

Labra ME. Capital social y consejos de salud en Brasil: un círculo virtuoso? Cad. Saúde Pública. 2002; 18(Supl): 47-55.

Labra ME, Figueredo JSA. Associativismo, participação e cultura cívica: o potencial dos conselhos de saúde. Ciênc. saúde coletiva. 2002; 7(3): 537-47

Labra ME. Conselhos de saúde: dilemas, avanços e desafios. In: Lima NT, Gerschman S, Edler FC, Suárez JM. (Orgs.). Saúde e democracia: história e perspectivas do SUS. Rio de Janeiro: Editora Fiocruz; 2005. p. 353-83.

Labra ME. É possível aferir a qualidade da representação dos usuários nos conselhos de saúde? Divulg. Saúde Deb. 2008; 43: 106-17.

Labra ME. Política Nacional de Participação na Saúde: entre a utopia democrática do controle social e a praxis predatória do clientelismo empresarial. In: Fleury S, Lobato LVC. (Orgs.). Participação, democracia e saúde. Rio de Janeiro: Cebes; 2009. p. 176-203.

Lucambo CW, Coutinho HG. Conselhos gestores e o processo de descentralização. São Paulo Perspec. 2004; 18(4): 62-72.

Luchmann LHH. A representação no interior das experiências de participação. Lua Nova. 2007; 70: 139-70.

Luchmann LHH. Participação e representação nos conselhos gestores e no orçamento participativo. Cad. CRH. 2008; 21(52): 87-97.

Ludke M, André MEDA. Pesquisa em educação: abordagens qualitativas. São Paulo: EPU; 1986.

Marcondes WB. A convergência de referências na promoção da saúde. Saúde soc. 2004; 13(1): 5-13.

Mendes DCVR. Representação política e participação: reflexões sobre o déficit democrático. Rev. Katálysis. 2007; 10(2): 143-53.

Minayo MCS. O desafio do conhecimento: pesquisa qualitativa em saúde. 2. ed. São Paulo - Rio de Janeiro: Hucitec - Abrasco; 1993.

Moreira MR. Democracia participativa, democracia representativa e conselhos de saúde no contexto da reforma política. Divulg. Saúde Deb. 2008; 43: 15-22. 
Moreira MR, Fernandes FMB, Sucena LFM, Oliveira NA. Participação nos conselhos municipais de saúde de municípios brasileiros com mais de cem mil habitantes. Divulg. Saúde Deb. 2008; 43: 48-61.

Moura JTV, Silva MK. Atores sociais em espaços de ampliação da democracia: as redes sociais em perspectiva. Rev. Sociol. Polit. 2008; 16(Supl): 43-54.

Nobre M. Participação e deliberação na teoria democrática: uma introdução. In: Coelho VSP, Nobre M. Participação e deliberação: teoria democrática e experiências institucionais no Brasil contemporâneo. São Paulo: Editora 34; 2004. p. 21-40.

Pelicioni MCF, Pelicioni AF. Educação e promoção da saúde: uma retrospectiva histórica. Mundo Saúde. 2007; 31(3): 320-8.

Pereira JCR. Análise de dados qualitativos: estratégias metodológicas para as ciências da saúde, humanas e sociais. São Paulo: Edusp-Fapesp; 1999.

Prefeitura Municipal de São Paulo. Portaria n 1.166, de 1989. Cria o Conselho Municipal de Saúde do município de São Paulo CMS/SP, nos termos do Regimento Interno em anexo. [portaria na internet]. [acesso em 07 ago 2009]. Disponível em:

http://www3.prefeitura.sp.gov.br/cadlem/secretarias/negocios_juri dicos/cadlem/pesqnumero. $a s p ? t=P \& n=1166 \& a=\& s=\& v a r=0$

Prefeitura Municipal de São Paulo. Lei $n^{\circ} 11.426$, de 18 de outubro de 1993. Cria a Secretaria Municipal do Verde e do Meio Ambiente - SVMA; cria o Conselho Municipal do Meio Ambiente e Desenvolvimento Sustentável - CADES. [lei na internet]. [acesso em 07 ago 2009]. Disponível em:

http://www3.prefeitura.sp.gov.br/cadlem/secretarias/negocios_juri dicos/cadlem/pesqnumero.asp?t $=\mathrm{L} \& \mathrm{n}=11426 \& \mathrm{a}=\& \mathrm{~s}=\& \mathrm{var}=0$

Prefeitura Municipal de São Paulo. Lei $n^{0} 12.546$, de 7 de janeiro de 1998a. Dispõe sobre o Conselho Municipal de Saúde de São Paulo, e dá outras providências. [lei na internet]. [acesso em 07 ago 2009]. Disponível em:

http://portal.prefeitura.sp.gov.br/secretarias/saude/legislacao/002 3

Prefeitura Municipal de São Paulo. Decreto no 37.330, de 16 de fevereiro de 1998b. Regulamenta a Lei no 12.546, de 7 de janeiro de 1998, que dispõe sobre o Conselho Municipal de Saúde do Município de São Paulo, e dá outras providências. [decreto na internet]. [acesso em 07 ago 2009]. Disponível em:

http://portal.prefeitura.sp.gov.br/secretarias/saude/legislacao/002 2 
Prefeitura Municipal de São Paulo. Decreto no 38.000, de 25 de maio de 1999a. Altera o Decreto no 37.330, de 16 de fevereiro de 1998, regulamentador da Lei no 12.546, de 7 de janeiro de 1998, que dispõe sobre o Conselho Municipal de Saúde do Município de São Paulo. [decreto na internet]. [acesso em 07 ago 2009]. Disponível em:

http://portal.prefeitura.sp.gov.br/secretarias/saude/legislacao/002 2

Prefeitura Municipal de São Paulo. Decreto no 38.576, de 5 de novembro de 1999b. Dá nova regulamentação à Lei no 12.546 , de 7 de janeiro de 1998; dispõe sobre a Conferência Municipal de Saúde, Conselho Municipal de Saúde, Conselhos Regionais de Saúde, Conselhos Distritais de Saúde, Conselhos Gestores das Unidades de Saúde, e dá outras providências. [decreto na internet]. [acesso em 07 ago 2009]. Disponível em:

http://portal.prefeitura.sp.gov.br/secretarias/saude/legislacao/000 1/\#1999

Prefeitura Municipal de São Paulo. Lei no 13.325, de 08 de fevereiro de 2002a. Dispõe sobre a organização de Conselhos Gestores nas Unidades do Sistema Único de Saúde, e dá outras providências. (PL 525/99) [lei na internet]. [acesso em 07 ago 2009]. Disponível em:

http://www3.prefeitura.sp.gov.br/cadlem/secretarias/negocios_juri dicos/cadlem/integra. asp?alt=09022002L\%20133250000

Prefeitura Municipal de São Paulo. Decreto no 42.005, de 17 de maio de 2002b. Regulamenta a Lei no. 13.325, de 8 de fevereiro de 2002, que dispõe sobre a Organização de Conselhos Gestores nas Unidades do Sistema Único de Saúde, e dá outras providências. [decreto na internet]. [acesso em 07 ago 2009]. Disponível em:

http://portal.prefeitura.sp.gov.br/secretarias/saude/legislacao/014 6

Prefeitura Municipal de São Paulo. Decreto no 42.862, de 13 de fevereiro de 2003. Institui o Conselho Municipal de Segurança Alimentar e Nutricional - COMUSAN-SP. [decreto na internet]. [acesso em 07 ago 2009]. Disponível em:

http://www3.prefeitura.sp.gov.br/cadlem/secretarias/negocios_juri dicos/cadlem/integra. asp?alt $=14022003$ D $\% 20428620000$

Prefeitura Municipal de São Paulo. Lei no 13.716, de 07 de janeiro de 2004a. Dispõe sobre a estrutura e a criação de cargos de provimento em comissão dos CEI 's e das Unidades de Saúde municipais, altera a Lei no 13.325 de 2002, que institui os Conselhos Gestores e nos Distritos de saúde, autoriza a realocação 
de recursos, e dá outras providências. (PL 835/03) [lei na internet]. [acesso em 07 ago 2009]. Disponível em:

http://www3.prefeitura.sp.gov.br/cadlem/secretarias/negocios_juri dicos/cadlem/integra.asp?alt $=08012004 \mathrm{~L} \% 20137160000$

Prefeitura Municipal de São Paulo. Decreto no 44.658, de 23 de abril de 2004b. Regulamenta a Organização de Conselhos Gestores nas Unidades do Sistema Único de Saúde e nas Coordenadorias de Saúde das Subprefeituras, instituídos pela Lei no 13.325, de 08 de fevereiro de 2002, com as Alterações Introduzidas pelos Artigos 20, 21 e 22 da Lei no 13.716, de Janeiro de 2004. [decreto na internet]. [acesso em 07 ago 2009]. Disponível em:

http://portal.prefeitura.sp.gov.br/secretarias/saude/legislacao/014 8

Prefeitura Municipal de São Paulo. Decreto no 50.126, de 17 de outubro de 2008. Confere nova disciplina ao Conselho Municipal de Segurança Alimentar e Nutricional - COMUSAN-SP e revoga o Decreto no 42.862, de 13 de fevereiro de 2003. [decreto na internet]. [acesso em 07 ago 2009]. Disponível em:

http://www3.prefeitura.sp.gov.br/cadlem/secretarias/negocios_juri dicos/cadlem/integra. asp?alt $=18102008 \mathrm{D} \% 20501260000$

Sacardo DP. Das políticas públicas às políticas públicas saudáveis: contribuições para a promoção da saúde. Mundo Saúde. 2004; 28(1): 5-13.

Scherer-Warren I. Cidadania sem fronteiras: ações coletivas na era da globalização. São Paulo: Hucitec; 1999.

Serapioni M, Romaní O. Potencialidades e desafios da participação em instâncias colegiadas dos sistemas de saúde: os casos de Itália, Inglaterra e Brasil. Cad. Saúde Pública. 2006; 22(11): 2411-21.

Sícoli JL, Nascimento PR. Promoção de saúde: concepções, princípios e operacionalização. Interface (Botucatu). 2003; 7(12): 101-22.

Silveira C, Bocayuva C, Zapata T. Ações integradas e desenvolvimento local: tendências, oportunidades e caminhos. In: Spink P, Caccia Bava S, Paulics V. Novos contornos da gestão local: conceitos em construção. São Paulo: Pólis; 2002. p. 245-70.

Souza C. Políticas Públicas: uma revisão da literatura. Sociologias. 2006; 8(16); 20-45.

SPSS Statistical Package for the Social Sciences ${ }^{\mathrm{TM}}$ for Windows ${ }^{\circledR}$, version 13. Chicago: SPSS Inc.; 2004. 
Tatagiba L. A institucionalização da participação: os conselhos municipais de políticas públicas na Cidade de São Paulo. In: Avritzer L. (Org.). A participação em São Paulo. São Paulo: UNESP; 2004. p. 323-70.

Tatagiba L. Os conselhos gestores e a democratização das políticas públicas no Brasil. In: Dagnino E. (Org.). Sociedade civil e espaços públicos no Brasil. São Paulo: Paz e Terra; 2002. p. 47-103.

Touraine A. O que é a democracia? 2. ed. Petrópolis: Vozes; 1996. Ugarte PS. Que participação para qual democracia? In: Coelho VSP, Nobre M. (Orgs.). Participação e deliberação: teoria democrática e experiências institucionais no Brasil contemporâneo. São Paulo: Editora 34; 2004. p. 93-106.

Vásquez ML, Silva MRF, Campos ES, Arruda IKG, Diniz AS, Veras IL, Pereira APC. Participação social nos serviços de saúde: concepções dos usuários e líderes comunitários em dois municípios do Nordeste do Brasil. Cad. Saúde Pública. 2003; 19(2): 579-91.

Viana ALDA. Novos riscos, a cidade e a intersetorialidade das políticas públicas. Rev. Adm. Publica. 1998; 32(2): 23-34.

Wampler B, Avritzer L. Públicos participativos: sociedade civil e novas instituições no Brasil democrático. In: Coelho VSP, Nobre M. (Orgs.). Participação e deliberação: teoria democrática e experiências institucionais no Brasil contemporâneo. São Paulo: Editora 34; 2004. p. 210-38.

Wendhausen A, Caponi S. O diálogo e a participação em um conselho de saúde em Santa Catarina, Brasil. Cad. Saúde Pública. 2002; 18(6): 1621-28.

Wendhausen A, Cardoso SM. Processo decisório e Conselhos Gestores de Saúde: aproximações teóricas. Rev Bras Enferm. 2007; 60(5): 579-84.

Wendhausen ALP, Barbosa TM, Borba MC. Empoderamento e Recursos para a participação em Conselhos Gestores. Saúde e soc. 2006; 15(3): 131-44.

Westphal MF. Promoção da saúde e prevenção de doenças. In: Campos GWS, Minayo MCS, Akerman M, Drumond Júnior M, Carvalho YM. (Orgs.). Tratado de Saúde Coletiva. São Paulo - Rio de Janeiro: Hucitec - Fiocruz; 2007. p. 635-67. 

7. ANEXOS 

ANEXO 1 - Gráfico de dispersão com os Distritos que compõem cada Subprefeitura do município de São Paulo e seus respectivos Índices de Exclusão Social (IEX), São Paulo, 2006 e 2007.

\section{Distritos por IEX}

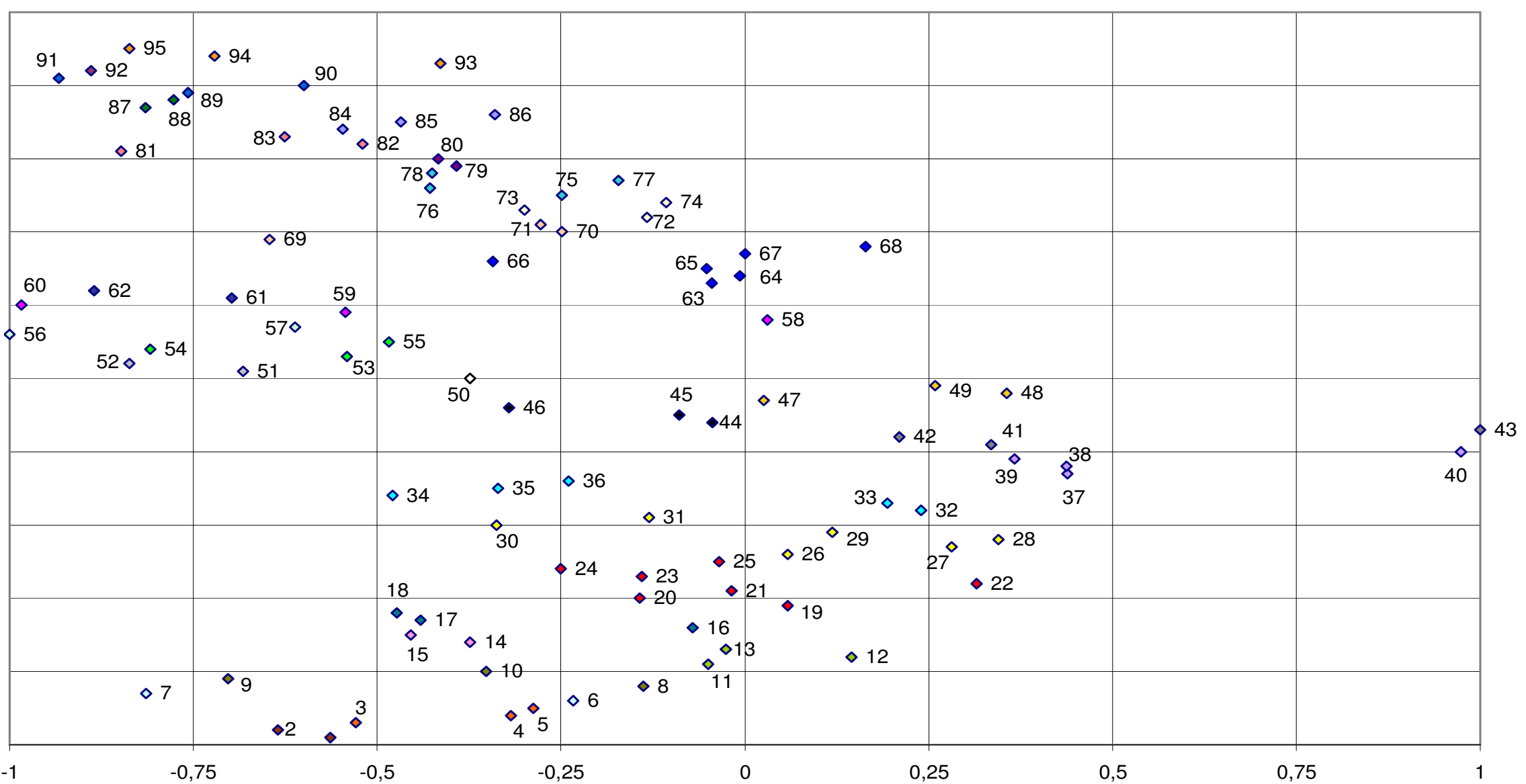

OBS: Os Distritos estão numerados e coloridos de acordo com a Subprefeitura a que pertencem, segundo a legenda a seguir. 
Legenda

\begin{tabular}{|c|c|c|c|}
\hline Subprefeitura & & Distrito & IEX \\
\hline \multirow[t]{2}{*}{ 1-Perus } & 1 & Anhaguera & $-0,564$ \\
\hline & 2 & Perus & $-0,635$ \\
\hline \multirow[t]{3}{*}{ 2-Pirituba } & 3 & Jaraguá & $-0,529$ \\
\hline & 4 & Pirituba & $-0,318$ \\
\hline & 5 & São Domingos & $-0,288$ \\
\hline \multirow[t]{2}{*}{ 3-Freguesia/Brasilândia } & 6 & Freguesia do Ó & $-0,233$ \\
\hline & 7 & Brasilândia & $-0,814$ \\
\hline \multirow[t]{3}{*}{ 4-Casa Verde/Cachoeirinha } & 8 & Casa Verde & $-0,138$ \\
\hline & 9 & Cachoeirinha & $-0,703$ \\
\hline & 10 & Limão & $-0,352$ \\
\hline \multirow[t]{3}{*}{ 5-Santana } & 11 & Mandaqui & $-0,05$ \\
\hline & 12 & Santana & 0,145 \\
\hline & 13 & Tucuruvi & $-0,026$ \\
\hline \multirow[t]{2}{*}{ 6-Tremembé/Jaçanã } & 14 & Jaçanã & $-0,374$ \\
\hline & 15 & Tremembé & $-0,454$ \\
\hline \multirow[t]{3}{*}{ 7-Vila Maria/Vila Guilherme } & 16 & Vila Guilherme & $-0,071$ \\
\hline & 17 & Vila Maria & $-0,441$ \\
\hline & 18 & Vila Medeiros & $-0,473$ \\
\hline \multirow[t]{7}{*}{ 8-Sé } & 19 & Bela Vista & 0,058 \\
\hline & 20 & Bom Retiro & $-0,143$ \\
\hline & 21 & Cambuci & $-0,018$ \\
\hline & 22 & Consolação & 0,315 \\
\hline & 23 & Liberdade & $-0,14$ \\
\hline & 24 & República & $-0,25$ \\
\hline & 25 & Santa Cecília & $-0,035$ \\
\hline \multirow[t]{6}{*}{ 9-Lapa } & 26 & Barra Funda & 0,058 \\
\hline & 27 & Lapa & 0,281 \\
\hline & 28 & Perdizes & 0,345 \\
\hline & 29 & Vila Leopoldina & 0,119 \\
\hline & 30 & Jaguaré & $-0,338$ \\
\hline & 31 & Jaguara & $-0,13$ \\
\hline \multirow[t]{5}{*}{ 10-Butantã } & 32 & Butantã & 0,24 \\
\hline & 33 & Morumbi & 0,194 \\
\hline & 34 & Raposo Tavares & $-0,479$ \\
\hline & 35 & Rio Pequeno & $-0,336$ \\
\hline & 36 & Vila Sonia & $-0,24$ \\
\hline \multirow[t]{4}{*}{ 11-Pinheiros } & 37 & Pinheiros & 0,439 \\
\hline & 38 & Alto de Pinheiros & 0,437 \\
\hline & 39 & Itaim Bibi & 0,367 \\
\hline & 40 & Jardim Paulista & 0,974 \\
\hline \multirow[t]{3}{*}{ 12-Vila Mariana } & 41 & Vila Mariana & 0,335 \\
\hline & 42 & Saúde & 0,21 \\
\hline & 43 & Moema & 1 \\
\hline \multirow[t]{3}{*}{ 13-Ipiranga } & 44 & Cursino & $-0,044$ \\
\hline & 45 & Ipiranga & $-0,089$ \\
\hline & 46 & Sacomã & $-0,321$ \\
\hline \multirow[t]{3}{*}{ 14-Santo Amaro } & 47 & Campo Grande & 0,026 \\
\hline & 48 & Santo Amaro & 0,356 \\
\hline & 49 & Campo Belo & 0,259 \\
\hline 15-Jabaquara & 50 & Jabaquara & $-0,374$ \\
\hline
\end{tabular}




\begin{tabular}{|c|c|c|c|}
\hline \multirow[t]{2}{*}{ 16-Cidade Ademar } & 51 & Cidade Ademar & $-0,682$ \\
\hline & 52 & Pedreira & $-0,837$ \\
\hline \multirow[t]{3}{*}{ 17-Campo Limpo } & 53 & Campo Limpo & $-0,541$ \\
\hline & 54 & Capão Redondo & $-0,809$ \\
\hline & 55 & Vila Andrade & $-0,484$ \\
\hline \multirow[t]{2}{*}{ 18-M'boi Mirim } & 56 & Jardim Ângela & -1 \\
\hline & 57 & Jardim São Luís & $-0,612$ \\
\hline \multirow[t]{3}{*}{ 19-Capela do Socorro } & 58 & \begin{tabular}{|l|} 
Socorro \\
\end{tabular} & 0,031 \\
\hline & 59 & Cidade Dutra & $-0,543$ \\
\hline & 60 & Grajaú & $-0,984$ \\
\hline \multirow[t]{2}{*}{ 20-Parelheiros } & 61 & Marsilac & $-0,698$ \\
\hline & 62 & Parelheiros & $-0,885$ \\
\hline \multirow[t]{6}{*}{ 21-Moóca } & 63 & Água Rasa & $-0,045$ \\
\hline & 64 & Moóca & $-0,007$ \\
\hline & 65 & Belém & $-0,052$ \\
\hline & 66 & Brás & $-0,343$ \\
\hline & 67 & Pari & 0 \\
\hline & 68 & Tatuapé & 0,164 \\
\hline \multirow[t]{3}{*}{ 22-Sapopemba } & 69 & Sapopemba & $-0,646$ \\
\hline & 70 & Vila Prudente & $-0,249$ \\
\hline & 71 & São Lucas & $-0,278$ \\
\hline \multirow[t]{3}{*}{ 23-Aricanduva } & 72 & Carrão & $-0,133$ \\
\hline & 73 & Aricanduva & $-0,3$ \\
\hline & 74 & Vila Formosa & $-0,107$ \\
\hline \multirow[t]{4}{*}{ 24-Penha } & 75 & Penha & $-0,249$ \\
\hline & 76 & Cangaíba & $-0,428$ \\
\hline & 77 & Vila Matilde & $-0,172$ \\
\hline & 78 & Artur Alvim & $-0,425$ \\
\hline \multirow[t]{2}{*}{ 25-Ermelino Matarazzo } & 79 & Ermelino Matarazzo & $-0,392$ \\
\hline & 80 & Ponte Rasa & $-0,417$ \\
\hline \multirow[t]{3}{*}{ 26-São Miguel } & 81 & Jardim Helena & $-0,848$ \\
\hline & 82 & São Miguel & $-0,52$ \\
\hline & 83 & Vila Jacuí & $-0,626$ \\
\hline \multirow[t]{3}{*}{ 27-Itaquera } & 84 & Itaquera & $-0,547$ \\
\hline & 85 & Parque do Carmo & $-0,468$ \\
\hline & 86 & Cidade Líder & $-0,34$ \\
\hline \multirow[t]{2}{*}{ 28-Itaim Paulista } & 87 & Itaim Paulista & $-0,815$ \\
\hline & 88 & Vila Curuçá & $-0,777$ \\
\hline \multirow[t]{3}{*}{ 29-Guaianases } & 89 & Guaianases & $-0,757$ \\
\hline & 90 & José Bonifácio & $-0,6$ \\
\hline & 91 & Lajeado & $-0,933$ \\
\hline 30-Cidade Tiradentes & 92 & Cidade Tiradentes & $-0,889$ \\
\hline \multirow[t]{3}{*}{ 31-São Mateus } & 93 & São Mateus & $-0,414$ \\
\hline & 94 & São Rafael & $-0,721$ \\
\hline & 95 & Iguatemi & $-0,837$ \\
\hline
\end{tabular}



ANEXO 2 - Roteiro estruturado para entrevista com conselheiros dos conselhos Municipais e Conselhos Gestores das Supervisões Técnicas de Saúde do município de São Paulo.

\section{UNIVERSIDADE DE SÃO PAULO FACULDADE DE SAÚDE PÚBLICA DEPARTAMENTO DE PRÁTICA DE SAÚDE PÚBLICA}

CONSELHOS MUNICIPAIS: POSSÍVEIS CONTRIBUIÇÕES PARA POLÍTICAS PÚBLICAS SAUDÁVEIS

NA PERSPECTIVA DA PROMOÇÃO DA SAÚDE

DATA APLICAÇÃO:

\section{PARTE I}

\section{A - Identificação do entrevistado}

A01 - Nome:

A02 - Endereço: Bairro:

A03 - CEP:

A04 - Tel. res.: Tel. cel.:

A05 - E-mail:

A06 - Sexo: 01- F 02- M

A07 - Data de Nascimento:

A08 - Conselho:

01- Municipal:

02- Supervisão de Saúde:

A09 - Há quanto tempo reside neste bairro? anos

A10 - A casa onde mora é:

01- própria 02- alugada 03- cedida

A11 - Escolaridade:

01- Analfabeto 02- $1^{\circ}$ grau incompleto $03-1^{\circ}$ grau completo

04- $2^{\circ}$ grau incompleto $05-2^{\circ}$ grau completo

06- $3^{\circ}$ grau incompleto

07- $3^{\circ}$ grau completo (Curso:

A12 - Atividade ocupacional: 
A13 - Renda individual mensal: $R \$$

A14 - Fonte de Renda (caso não trabalhe):

A15 - Local de trabalho (se é servidor público ou não)

A16 - Quais os principais meios de informação utilizados por você?

01- jornal e/ou revista 03- Internet

02- televisão e/ou rádio 04- outros, quais?

A17 - Essas fontes de informação são satisfatórias?
$01-\mathrm{S}$
02- $\mathrm{N}$

A18 - Por que?

A19 - Representação no conselho:

01- Titular 02- Suplente

A20 - Segmento no conselho:

01- Administração 02- Trabalhadores da área 03- Usuários

Se A20 for 01 ou 02, passe para a questão A24.

A21 - Qual associação e/ou entidade representa?

A22 - Há quanto tempo participa desta associação e/ou entidade?

01- menos de 1 ano 02- de 1 a 3 anos

03- de 3 a 5 anos 04- mais de 5 anos

A23 - Qual função exerce nesta associação e/ou entidade?

A24 - Participa de alguma (outra) entidade e/ou associação?

$01-\mathrm{S}$

$02-N$

Se $A 24$ for 02 e $A 20$ for 03 , pule a questão $A 25$ e passe para a questão B01.

Se A24 for 02 e A20 for 01 ou 02, passe para a Parte C do questionário.

A25 - Qual(is)?

$01)$

02)

03) 
Se A20 for 01 ou 02, pule a Parte B (Identificação da associação e/ou entidade que representa) e passe para a questão C02 na Parte C do questionário.

\section{B-Identificação da associação e/ou entidade que representa}

B01-Nome:

B02 - Endereço:

B03 - CEP:

B04 - Tel.:

B05 - E-mail:

B06 - Site da associação e/ou entidade:

B07 - Número aproximado de membros da associação e/ou entidade:

01- menos de 10 membros 03- de 30 a 100 membros

02- de 10 a 30 membros 04- mais de 100 Membros

B08 - Qual a atuação da entidade?

B09 - Quais seus principais objetivos?

$01)$.

02).

03).

B10 - Quais as principais atividades desenvolvidas?

01).

02).

03).

B11 - Qual a abrangência geográfica da atuação da associação e/ou entidade?

01- local 02- municipal 03- estadual 04- nacional

B12 - Como são escolhidos os representantes da associação e/ou entidade para participar dos Conselhos e Fóruns locais, distritais e municipais?

01- eleição 03- voluntariamente

02- indicação

04- outra. Qual?

B13 - Sua associação e/ou entidade tem relação com outras associações e/ou entidades da região ou da cidade?

$$
\text { 01- } \mathrm{S} \quad 02-\mathrm{N}
$$

Se a resposta for não, passe para a Parte $C$.

B14 - Se sim, com quais? 
B15 - E de que forma?

\section{C- Percepção sobre as instâncias de participação e possibilidades de intervenção nas políticas públicas}

C01 - Por que a associação e/ou entidade que você representa tem interesse em participar desse Conselho?

C02 - Por que o segmento que você representa (administração ou trabalhadores da área da saúde) tem interesse em participar desse Conselho?

C03 - Esse Conselho influencia na formulação e implantação de políticas públicas? (ações do governo)

$$
01-\mathrm{S} \quad 02-\mathrm{N}
$$

Se a resposta for não, passe para Parte II do questionário.

C04 - Como?

\section{PARTE II}

D01 - Qual o significado de participar desse Conselho para você?

D02 - (para representante do segmento de usuário) E para a associação e/ou entidade que representa?

D03 - (para representante do segmento da administração ou de trabalhadores da área da saúde) Qual o significado de participar desse conselho para o segmento que representa?

D04 - Como é a relação entre os membros desse Conselho, em geral?

D05 - E entre os que são representantes do mesmo segmento?

D06 - E entre os representantes de diferentes segmentos?

D07 - E como é a relação, fora das instâncias formais de participação, entre as associações e/ou entidades que são representadas nesse Conselho?

D08 - Como são tomadas as decisões nesse Conselho? 
D09 - Quais temas estão na pauta / agenda deste Conselho?

D10 - Qual a sua expectativa e da associação e/ou entidade que representa sobre a influência desse Conselho na formulação e implantação de políticas públicas (integradas / intersetoriais)?

D11 - Por que?

D12 - O que você sabe sobre o funcionamento de outros Conselhos Municipais / Conselhos de Supervisões de Saúde?

D13 - A população relaciona-se com esse Conselho?

01- $S \quad 02-\mathrm{N}$

Se a resposta for não, passe para a questão D16.

D14 - De que forma?

D15 - Para que? Exemplifique.

D16 - Como é a relação entre os responsáveis pela gestão administrativa municipal/local com este Conselho?

D17 - Por que?

D18 - Exemplifique:

D19 - Existem políticas intersetoriais (municipais / regionais / locais)? $01-\mathrm{S} \quad 02-\mathrm{N}$

Se a resposta for não, pule as próximas questões.

D20 - Quais?

D21 - Como foram formuladas e implantadas? 

ANEXO 3 - Roteiro para observação das reuniões dos Conselhos Gestores das Supervisões Técnicas de Saúde.

\begin{tabular}{|c|c|}
\hline & \\
UNIVERSIDADE DE SÃO PAULO \\
DEPACULDADE DE SAÚDE PÚBLICA \\
DEPTAMENTO DE PRÁTICA DE SAÚDE PÚBLICA
\end{tabular}

\title{
CONSELHOS MUNICIPAIS: POSSÍVEIS CONTRIBUIÇÕES PARA POLÍtICAS PÚBLICAS SAUDÁVEIS NA PERSPECTIVA DA PROMOÇÃO DA SAÚDE
}

\section{ROTEIRO PARA OBSERVAÇÃO DAS REUNIÕES}

\author{
DATA APLICAÇÃO:
}

Conselho Supervisão Técnica de Saúde:

1. Organização prévia da reunião

- A pauta foi previamente encaminhada para os conselheiros?

- O material foi disponibilizado anteriormente aos conselheiros?

2. Infra-estrutura das reuniões

- Localização da reunião (Fácil acesso? Houve discussão com os conselheiros para escolha do local?)

- Como era a disposição das cadeiras na sala? Possibilitava a participação de todos?

3. Organização da reunião

- Como foi estruturada a pauta da reunião?

4. Participação dos membros

- Todos os membros participaram? Alguém se sobressaiu? Representante de que segmento? De que entidade e/ou associação? Onde estava sentada?

- Quem (segmento, entidade e/ou associação) fez ou trouxe propostas?.

5. Participação de outras pessoas, não membros

- Houve convidados? Foram convidados por qual representante, segmento, entidade e/ou associação?

6. Temas abordados

- Quais foram os principais temas abordados?

- Qual foi aquele que demandou mais tempo?

- A pauta foi cumprida?

7. Processo de tomada de decisões

- Discussão? Votação? Consenso?

- Houve discussão prévia? Algum segmento ou representante ou entidade e/ou associação argumentou em seu próprio benefício? 

ANEXO 4 - Composição do Conselho Municipal do Meio Ambiente e Desenvolvimento Sustentável de São Paulo (CADES).

Mandato 2006-2007

\begin{tabular}{|c|c|}
\hline Administracão & Soc \\
\hline $\begin{array}{ll}\text { - } & \text { Secretaria do Governo Municipal - SGM } \\
\text { - } & \text { Secretaria de Serviços e Obras - SSO } \\
\text { - } & \text { Secretaria da Habitação e Desenvolvimento Urbano - SEHAB } \\
\text { - } & \text { Secretaria Municipal da Educação - SME } \\
\text { - } & \text { Secretaria Municipal de Planejamento - SEMPLA } \\
\text { - } & \text { Secretaria Municipal de Transportes - SMT } \\
\text { - } & \text { Secretaria de Vias Públicas - SVP } \\
\text { - } & \text { Secretaria Municipal da Saúde - SMS } \\
\text { - } & \text { Secretaria das Administrações Regionais - SAR } \\
\text { - } & \text { Secretaria Municipal de Cultura - SMC } \\
\text { - } & \text { Secretaria dos Negócios Jurídicos - SJ } \\
\text { - } & \text { Diretores dos Departamentos da Secretaria Municipal do } \\
& \text { Verde e do Meio Ambiente } \\
\text { - } & \text { Ministério do Meio Ambiente } \\
\text { - } & \text { Secretaria de Estado do Meio Ambiente de São Paulo } \\
\text { - } & \text { Companhia de Tecnologia de Saneamento Ambiental - CETESB } \\
\text { - } & \text { Ministério Público do Estado de São Paulo } \\
\text { - } & \text { Câmara Municipal de São Paulo }\end{array}$ & $\begin{array}{l}\text { - } 1 \text { Representante das Universidades sediadas no Município de } \\
\text { - } \\
\text { - } 1 \text { Rão Paulo - Universidade Mackenzie } \\
\text { - } 1 \text { representante do Setor Industrial - FIESP } \\
\text { - } 1 \text { Representante do Setor Comercial - FECOMERCIO } \\
\text { - } 1 \text { Representante da OAB } \\
\text { - } 1 \text { Representante escolhido entre os indicados pelas entidades: } \\
\text { Instituto dos Arquitetos do Brasil, Instituto de Engenharia e } \\
\text { Associação Brasileira de Engenharia Sanitária e Ambiental - } \\
\text { ABES } \\
\text { 3 Representantes de Organizações Não Governamentais - } \\
\text { ONG's, com tradição na defesa do meio ambiente - SAJA } \\
\text { (Associação dos Amigos do Jaguaré), Movimento Defenda São } \\
\text { Paulo e Associação dos Moradores do Jardim Saúde } \\
\text { - } 1 \text { Representante das Centrais Sindicais - Força Sindical } \\
\text { - } 2 \text { Observadores de órgãos públicos }\end{array}$ \\
\hline
\end{tabular}

Fonte: (http://portal.prefeitura.sp.gov.br/secretarias/meio_ambiente/cades/0003) 

ANEXO 5 - Composição do Conselho Municipal de Saúde de São Paulo (CMS).

Mandato 2006-2007

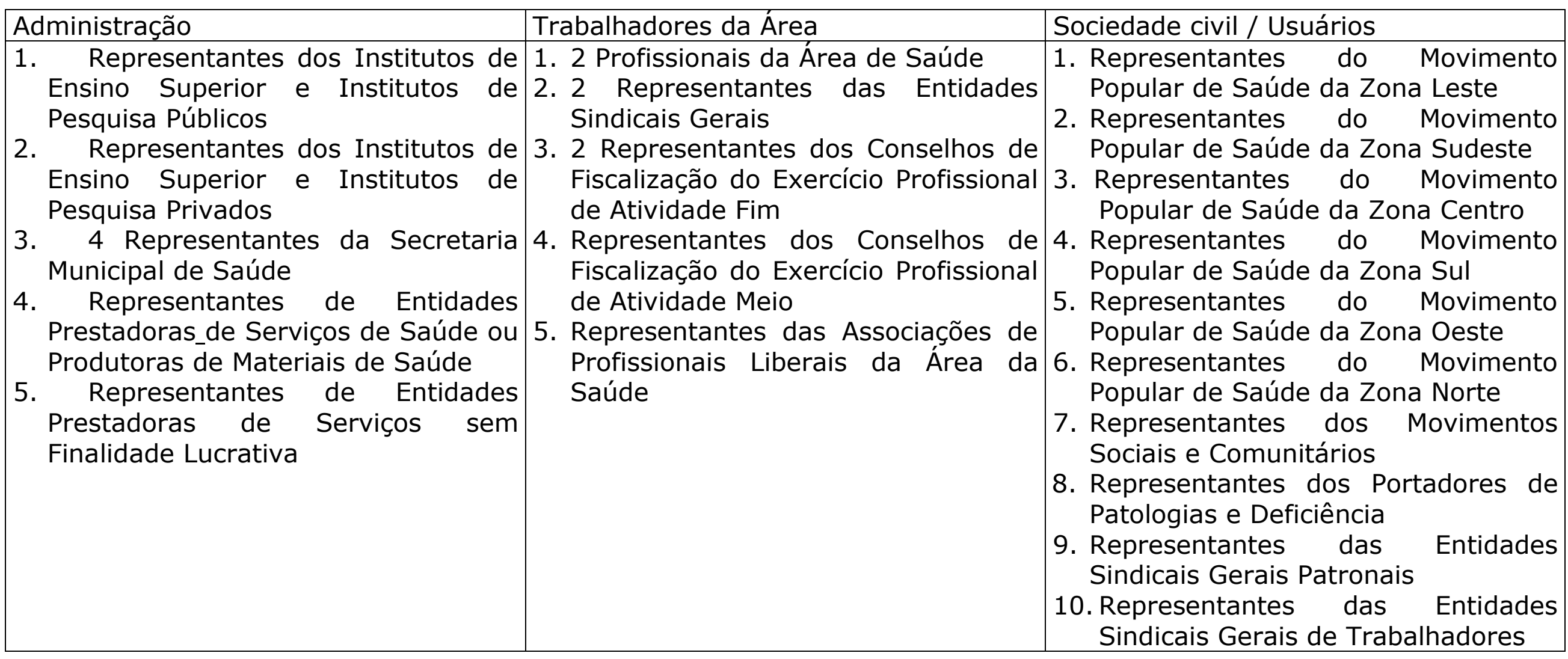

Fonte: (http://portal.prefeitura.sp.gov.br/secretarias/saude/cms/0004) 

ANEXO 6 - Composição do Conselho Municipal de Segurança Alimentar e Nutricional de São Paulo (COMUSAN).

Mandato 2006-2007

Administração Secretaria Municipal de Serviços

2. Secretaria Municipal de Saúde, Secretaria Municipal de Saúde

3. Secretaria Municipal de Educação, Secretaria Municipal de Educação

4. Secretaria Municipal de Assistência e Desenvolvimento Social, Secretaria Municipal de Assistência e Desenvolvimento Social

5. Secretaria de Estado da Saúde, Secretaria de Estado da Saúde

6. Secretaria de Estado da Agricultura e Abastecimento, Secretaria de Estado da Agricultura e Abastecimento

7. Centro Estadual de Educação Tecnológica Paula Souza, Centro Estadual de Educação Tecnológica Paula Souza

8. Universidade de São Paulo, Universidade de São Paulo

9. Ministério do Desenvolvimento Social, Ministério do Desenvolvimento Social

10. Câmara Municipal de São Paulo, Câmara Municipal de São Paulo
REPRESENTANTES DE ENTIDADES SINDICAIS DE TRABALHADORES

1. Sindicato dos Médicos Veterinários, Sindicato dos Médicos Veterinários

2. Sindicato dos Agentes Vistores, Sindicatos dos Engenheiros

3. Sindicato dos Nutricionistas, Sindicato dos Nutricionistas

REPRESENTANTES DE ASSOCIAÇÕES DE TRABALHADORES

4. Associação Paulista de Nutrição, Associação Paulista de Nutrição

5. Associação Brasileira dos Engenheiros de Alimentos, Associação Brasileira dos Engenheiros de Alimentos

6. Colégio Brasileiro de Médicos

Veterinários, Colégio Brasileiro de Médicos

Veterinários

7. Colégio Brasileiro de Médicos

Veterinários, Associação Brasileira dos

Engenheiros de Alimentos

REPRESENTANTES DE CONSELHO DE

CLASSE

8. Conselho Regional de Química - $4^{a}$

Região, Conselho Regional de Nutricionistas - 3a Região

9. Conselho Regional de Nutricionistas - $3^{a}$ Região, Conselho Regional de Enfermagem de SP

10. Conselho Regional de Medicina

Sociedade Civil

REPRESENTANTES DOS MOVIMENTOS

POPULARES E COMUNITÁRIOS

1. Ação da Cidadania, Associação Amigos

Parque Raposo Tavares

2. Movimento Alternativo de Transformação Social, Associação Prato Cheio

3. Conselho Popular de Saúde do Jabaquara, Clube da $3^{a}$ Idade Presidente Altino

4. Ten-Yad, Centro Acadêmico Emílio Ribas

5. Associação Beneficente Vila Araguaia,

Associação Mont Blue 3000

REPRESENTANTES DAS ENTIDADES

SINDICAIS E ASSOCIAÇÕES GERAIS

PATRONAIS

6. SINDIPAN, ABIA

7. APRAG, ABERC

8. APAS, ABRAS

9. $A B P A, A B P A$

10.SESC, APAS

obs.: no segundo ano, haverá a inversão da

titularidade e da suplência, entre os

membros desse sub-segmento.

REPRESENTANTES DAS INSTITUIÇÕES DE ENSINO PRIVADO

11. Universidade São Judas Tadeu, Universidade São Judas Tadeu

12. UNINOVE, UNINOVE

13. FISP, Centro Universitário São Camilo

obs.: no 13 - no segundo ano, haverá a

inversão da titularidade e da suplência 


\begin{tabular}{|c|c|c|}
\hline Administração & Trabalhadores da Área & Sociedade Civil \\
\hline & $\begin{array}{l}\text { Veterinária de SP, Conselho Regional de } \\
\text { Engenharia, Arquitetura e Agronomia de SP }\end{array}$ & $\begin{array}{l}\text { PORTADORES DE PATOLOGIAS E ENTIDADES } \\
\text { DE PORTADORES DE DEFICIÊNCIAS } \\
\text { 14. ACELBRA, ADJ } \\
\text { 15. APAF, ACELBRA } \\
\text { 16. Movimento pelos Direitos das Pessoas } \\
\text { Deficientes, Movimento pelos Direitos das } \\
\text { Pessoas Deficientes } \\
\text { REPRESENTANTES DA ECONOMIA INFORMAL } \\
\text { E DE ENTIDADES PRESTADORAS DE } \\
\text { SERVIÇOS RELACIONADOS À SEGURANÇA } \\
\text { ALIMENTAR E NUTRICIONAL } \\
\text { 17. Instituto Polis, Não eleito, sem } \\
\text { representação na Conferência } \\
\text { 18. Não eleito, sem representação na } \\
\text { Conferência, Não eleito, sem representação } \\
\text { na Conferência } \\
\text { 19. Não eleito, sem representação na } \\
\text { Conferência, Não eleito, sem representação } \\
\text { na Conferência } \\
\text { 20. Não eleito, sem representação na } \\
\text { Conferência, Não eleito, sem representação } \\
\text { na Conferência }\end{array}$ \\
\hline
\end{tabular}

Obs: As vagas estão dispostas por segmento, sendo que o primeiro nome corresponde ao titular e o segundo ao suplente.

Fonte: (http://portal.prefeitura.sp.gov.br/secretarias/abastecimento/comusan/organizacao/0009) 
ANEXO 7 - Roteiro estruturado para entrevista com responsáveis técnicos pelos Conselhos Gestores das Supervisões Técnicas de Saúde.

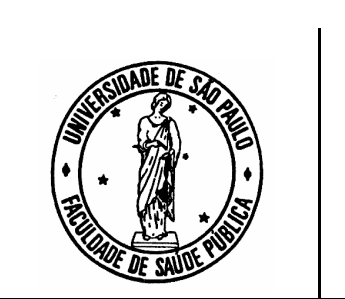

\section{UNIVERSIDADE DE SÃO PAULO \\ FACULDADE DE SAÚDE PÚBLICA \\ DEPARTAMENTO DE PRÁTICA DE SAÚDE PÚBLICA}

CONSELHOS MUNICIPAIS: POSSÍVEIS CONTRIBUIÇÕES PARA POLÍTICAS PÚBLICAS SAUDÁVEIS

NA PERSPECTIVA DA PROMOÇÃO DA SAÚDE

ROTEIRO PARA ENTREVISTA COM RESPONSÁVEIS TÉCNICOS DOS CONSELHOS GESTORES DAS SUPERVISÕES TÉCNICAS DE SAÚDE

DATA APLICAÇÃO:

Conselho da Supervisão Técnica de Saúde de

1. Como aconteceu a formação deste Conselho? (histórico e processo de formação)

2. Quando e como acontecem as eleições?

3. Como foi definida a composição do Conselho (por pessoa ou por entidade)?

4. Como é feita a escolha dos membros do segmento da administração?

5. Existem critérios para as pessoas se candidatarem? Quais são?

6. Como foi escolhido o coordenador deste Conselho?

7. O que você sabe quanto ao repasse de informações dos membros do Conselho para a os seus representados e para a comunidade em geral?

8. Este Conselho possui Regimento Interno? Como foi construído? 

ANEXO 8 - Parecer do Comitê de Ética em Pesquisa da Faculdade de Saúde Publica da USP.

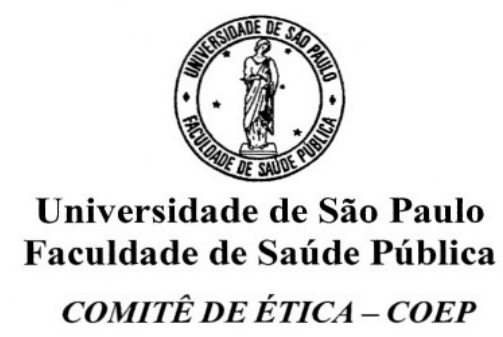

Av. Dr. Arnaldo, 715 - Assessoria Acadêmica - CEP 01246-904 - São Paulo - Brasil Telefones: (55-11) 3066-7779 - e-mail: coep@fsp.usp.br

\section{Of.COEP/225/05}

10 de novembro de 2005

Pelo presente, informo que o Comitê de Ética em Pesquisa da Faculdade de Saúde Pública da Universidade de São Paulo-COEP, aprovou em sua 9. º5 Sessão Ordinária, realizada em 09.11.05, de acordo com os requisitos da Resolução CNS/196/96 e suas complementares, o protocolo de pesquisa n. ${ }^{\circ}$ 1373, intitulado: "CONSELHOS MUNICIPAIS: POSSÍVEIS CONTRIBUIÇÕES PARA POLÍTICAS SAUDÁVEIS NA PERSPECTIVA DA PROMOÇÃO DA SAÚDE”, apresentado pela pesquisadora Cláudia Maria Bógus.

Atenciosamente,

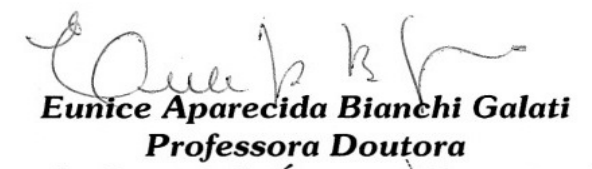

Coordenadora do Comitê de Ética em Pesquisa da FSP-COEP 



\section{ANEXO 9 - Parecer do Comitê de Ética em Pesquisa da Secretaria Municipal de Saúde de São Paulo.}

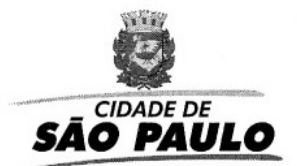

SECRETARIA DA SAÚDE
Prefeitura do Município de São Paulo

Secretaria Municipal da Saúde Coordenação de Desenvolvimento da

Gestão Descentralizada - COGest Comitê de Ética em Pesquisa

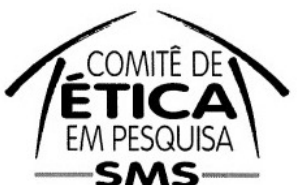

SMS

São Paulo, 18 de outubro de 2005.

\section{PARECER N ${ }^{\circ} 130 / / 2005-$ CEPSMS}

\section{Prezado (a) Senhor (a)}

Pelo presente, informo que o Comitê de Ética em Pesquisa da Secretária Municipal de Saúde de São Paulo analisou, e APROVOU, de acordo com a Resolução CNS 196/96, o protocolo de pesquisa "Conselhos Municipais: As possíveis contribuiçõ̃es para Políticas Públicas Saudáveis na Perspectiva da Promoção da Saúde" - CAAE 0091/05, de autoria do(a) pesquisador(a) Cláudia Maria Bógus

Como procedimento adotado por este Comitê de Ética em Pesquisa, solicitamos a inclusão, no Termo de Consentimento Livre e Esclarecido do seguinte: qualquer questão, dúvida, esclarecimento ou reclamação sobre os aspectos éticos dessa pesquisa, favor entrar em contato com: Comitê de Ética em Pesquisas da Secretaria Municipal da Saúde de São Paulo - Rua General Jardim, $36-2^{\circ}$ andar Telefone: 3218-4043 - e-mail: smscep@prefeitura.sp.gov.br

Lembramos que este parecer não basta para que seu estudo possa se realizar dentro da unidade, é necessária também a permissão administrativa da autoridade sanitária.

Salientamos os seguintes aspectos a serem considerados pelo pesquisador:

- O sujeito da pesquisa tem a liberdade de recusar-se a participar ou de retirar seu consentimento em qualquer fase da pesquisa, sem penalização alguma ou sem prejuízo ao seu cuidado (Res. CNS 196/96 - item IV.1f) e deve receber uma cópia do Termo de Consentimento livre e esclarecido, na íntegra, por ele assinado (item IV.2.d)

- O pesquisador deve desenvolver a pesquisa conforme delineada no protocolo aprovado. Eventuais modificações ou emendas ao protocolo devem ser apresentadas ao CEP de forma clara e sucinta, identificando a parte do protocolo a ser modificada e suas justificativas. O relatório final deve ser apresentado ao CEP, logo que o estudo estiver concluído.

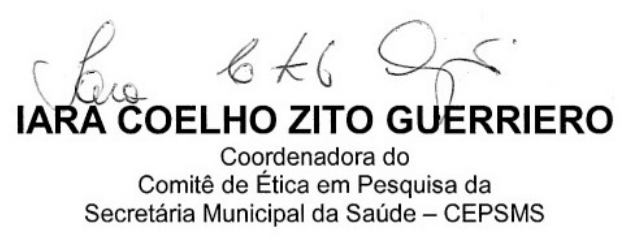

Ilustríssima Senhora Doutora

CLÁUDIA MARIA BÓGUS

NESTA

Rua General Jardim, $36-2^{\circ}$ andar - Vila Buarque - São Paulo, SP - CEP 01223-010 Telefone: (11) 3218-4043 e-mail: smscep@prefeitura.sp.gov.br homepage: http://portal.prefeitura.sp.gov.br/secretarias/saude/organizacao/cepsms/ 

ANEXO 10 - Termo de consentimento livre e esclarecido para os participantes do Projeto Conselhos Municipais: possíveis contribuições para políticas públicas saudáveis na perspectiva da promoção da saúde.

\section{UNIVERSIDADE DE SÃO PAULO FACULDADE DE SAÚDE PÚBLICA DEPARTAMENTO DE PRÁTICA DE SAÚDE PÚBLICA}

\section{TERMO DE CONSENTIMENTO LIVRE E ESCLARECIDO}

Declaro que obtive as informações necessárias e suficientes sobre os procedimentos da pesquisa "Conselhos Municipais: possíveis contribuições para políticas públicas saudáveis na perspectiva da promoção da saúde", cuja pesquisadora responsável é Cláudia Maria Bógus, que estará disponível para discutir e esclarecer quaisquer dúvidas sobre o trabalho, em qualquer etapa do estudo.

Declaro que participo voluntariamente nesta pesquisa que pretende realizar um estudo junto aos Conselhos Municipais e Conselhos Gestores de Supervisões Técnicas de Saúde do município de São Paulo, com o objetivo de (1) identificar o perfil sóciodemográfico dos seus membros; (2) identificar as associações e/ou entidades a que pertencem os membros; (3) caracterizar e analisar o perfil das associações e/ou entidades a que pertencem os membros dos referidos Conselhos e as relações existentes entre elas e (4) identificar a percepção dos membros quanto às possibilidades de articulação e integração dos conselhos na formulação de políticas públicas intersetoriais.

Declaro, também, que foram assegurados o anonimato e o sigilo sobre minhas declarações, assim como o direito de não participar ou retirar-me da pesquisa em qualquer fase, sem que isso implique em penalidades de qualquer natureza, permanecendo as garantias a mim oferecidas.

Declaro que, após ter sido convenientemente esclarecido pelo pesquisador e ter entendido o que me foi explicado, consinto em:

( ) responder e participar voluntariamente da entrevista.

( ) permitir voluntariamente a gravação da entrevista.

São Paulo, 1

Nome:

RG:

Assinatura do participante Assinatura do responsável pela pesquisa

Para quaisquer outros esclarecimentos, favor contatar: Cláudia Maria Bógus - Faculdade de Saúde Pública da Universidade de São Paulo; Tel.: 3061-7761; E-mail: claudiab@usp.br Qualquer questão, dúvida, esclarecimento ou reclamação sobre os aspectos éticos dessa pesquisa, favor entrar em contato com: Comitê de Ética em Pesquisas da Secretaria Municipal da Saúde de São Paulo - Rua General Jardim, 36 - 20 andar - Tel.: 32184043 e/ou Comitê de Ética em Pesquisa da Faculdade de Saúde Pública da USP - Av. Dr. Arnaldo, 715 - Tel.: 30617742. 
